Universidade de São Paulo

Faculdade de Filosofia, Letras e Ciências Humanas

Departamento de Geografia

Programa de Pós-Graduação em Geografia Humana

\title{
A PRODUÇÃO DO ESPAÇO COMO MERCADORIA: NOVOS EIXOS DE VALORIZAÇÃO IMOBILIÁRIA EM PORTO ALEGRE/RS
}

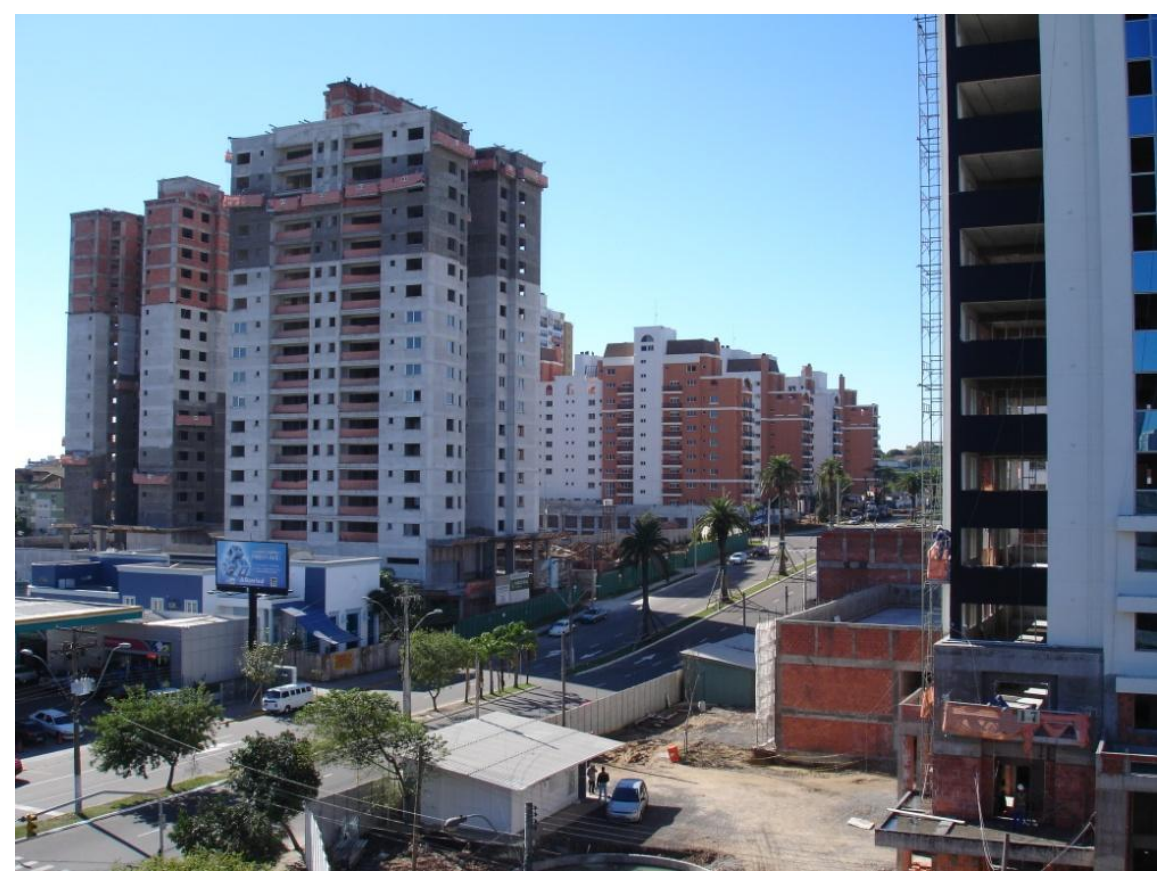

Daniel de Mello Sanfelici

São Paulo Março de 2009 
Daniel de Mello Sanfelici

A PRODUÇÃO DO ESPAÇO COMO MERCADORIA:

novos eixos de valorização imobiliária em Porto Alegre/RS

Dissertação de Mestrado apresentada ao Programa de Pós-Graduação em Geografia Humana da Universidade de São Paulo, como requisito parcial para a obtenção do título de Mestre em Geografia.

Orientadora: Prof $^{\mathrm{a}}$ Amélia Luísa Damiani

São Paulo

2009 
Daniel de Mello Sanfelici

A produção do espaço como mercadoria: novos eixos de valorização imobiliária em Porto Alegre/RS.

Dissertação apresentada à Faculdade de Filosofia, Letras e Ciências Humanas para obtenção do título de Mestre em Geografia.

Área de concentração: Geografia Humana.

Aprovado em:

\section{Banca examinadora:}

Prof ${ }^{\mathrm{a}}$ Dra

Instituição:

Assinatura:

Prof. Dr.:

Instituição: Assinatura:

Prof ${ }^{a}$ Dra:

Instituição: Assinatura: 


\section{AGRADECIMENTOS}

Agradeço, em primeiro lugar, à minha orientadora, Amélia Damiani, que abriu as portas para que eu viesse para São Paulo, confiando em que meu trabalho pudesse oferecer uma contribuição ao trabalho que outros colegas já desenvolviam no Labur. Agradeço a ela, também, por ter oferecido seu apoio nos primeiros meses em que estive em São Paulo, o que facilitou muito essa transição e, obviamente, agradeço por suas orientações, sugestões e críticas e comentários sobre o trabalho, que me ajudaram a definir melhor o problema e a buscar as respostas. Também devo muito das reflexões aqui desenvolvidas aos grupos de estudos organizados pela Amélia no Labur e às suas disciplinas. Enfim, sua competência e dedicação foram um estímulo sempre presente nesse caminho. Por tudo isso, minha imensa gratidão.

À professora Ana Fani Alessandri Carlos, pelo acolhimento nos grupos de estudo e pela disciplina de Pós-graduação, que me proporcionou um caminho para fazer uma leitura mais atenta da obra de Henri Lefebvre, e também pelas críticas e sugestões na banca de qualificação.

À professora Odette Seabra pelas colocações e sugestões muito pertinentes na banca de qualificação, o que me ajudou a definir melhor os rumos que a pesquisa ainda poderia tomar.

Agradeço muitíssimo ao professor Álvaro Heidrich, da UFRGS, meu orientador de iniciação científica, por que sempre me deixou livre para escolher os caminhos que eu desejasse e por sua orientação sempre muito cuidadosa e sua disponibilidade em esclarecer dúvidas e oferecer sugestões. Acima de tudo, agradeço-lhe por ter-me incentivado a tentar o processo seletivo em São Paulo.

À professora Tânia Strohaecker por ter oferecido sugestões e facilitado alguns caminhos para que eu desenvolvesse o trabalho de campo em Porto Alegre. Ao professor Oscar Sobarzo, que conheci no ano passado, quando fiquei em Porto Alegre para realizar os trabalhos de campo necessários, agradeço por ter-me permitido assistir suas aulas de Pós-graduação, que foram extremamente enriquecedoras. 
Ao Rodrigo (Chaves) pela ajuda com os mapas, sem a qual eu dificilmente conseguiria completar essa parte da dissertação.

Às empresas que ofereceram informações e permitiram que eu realizasse entrevistas, contrastando imensamente com aquelas que negavam qualquer auxílio.

Aos amigos que fiz em São Paulo, por terem tornado essa experiência de viver longe da família muito mais fácil, tendo me acolhido em todos os momentos. Também é preciso reiterar o quanto essa reflexão depende das discussões que fizemos em grupos de estudos, fundamentais ao debate de idéias e à formação teórica mais ampla. Quero mencionar aqui especialmente o Júnior (sempre com tiradas engraçadíssimas, ótimo parceiro de estudos), a Renata (com quem eu converso desde os primeiros dias em São Paulo), o Baldraia (sempre disposto a ajudar quem quer que seja), o César (a leitura sem ele fica incompleta), o James, o lgor, mas também vários outros colegas e amigos do Labur ou de fora (menciono alguns, correndo o risco de omitir outros: Sávio, Rafael, Danilo, Bona, Paulão, etc).

Aos amigos de Porto Alegre, que conheci durante a graduação, muitos dos quais mantenho contato pelos diversos meios (Gringo, Cezinha, Eduardo, etc) e aos outros amigos, que conheci de outras formas. Em especial, nesse último caso, devo mencionar o Rodrigo e a Nanda, de quem tive a oportunidade de me aproximar nesse último ano que fiquei em Porto Alegre, e cuja amizade eu prezo demais e pretendo preservar mesmo à distância.

À Karen, meu amor, pessoa que eu tanto admiro e de quem desejo sempre estar próximo, compartilhando os momentos bons e os momentos difíceis. Agradeço especialmente pela compreensão nesses momentos finais em que tive que dedicar às leituras, à redação final do trabalho, etc. $E$ agradeço demais pelas ajudas (sempre de coração, como é do seu feitio), pelo apoio, pelo carinho e pelo afeto. Te amo muito!

Aos meus familiares mais próximos em geral, mas dedico um agradecimento especial aos meus pais. É difícil encontrar palavras para expressar a gratidão que tenho por eles. É deles que herdei não apenas o gosto pelo estudo e pelo conhecimento, que permitiu a redação desse trabalho, mas também os valores que definem boa parte do que sou. A eles também devo muito pelo apoio incondicional em todos os momentos, em particular 
nessa vinda para São Paulo. O distanciamento do convívio diário com eles é o que mais foi difícil nessa mudança de cidade.

Destaquei o caráter coletivo que uma reflexão como essa possui, e por isso o agradecimento aos colegas de estudo e de debate. Qualquer eventual insuficiência ou equívoco do trabalho, contudo, devem ser atribuídos unicamente ao autor.

Esta pesquisa recebeu auxílio, a partir de agosto de 2007, do CNPq. 


\section{RESUMO}

SANFELICI, Daniel de Mello. A produção do espaço como mercadoria: novos eixos de valorização imobiliária em Porto Alegre/RS. 2009. 145f. Dissertação (Mestrado) - Faculdade de Filosofia, Letras e Ciências Humanas. Universidade de São Paulo, 2009.

A pesquisa aqui desenvolvida visou elucidar os nexos que definem a produção do espaço da metrópole de Porto Alegre no período atual, sobretudo nos últimos 15 anos. O trabalho inicialmente estabelece os fundamentos teóricos para compreender o movimento que transforma o espaço urbano em mercadoria, para em seguida identificar como esse processo se desenvolve, em Porto Alegre, definindo centralidades de valorização no espaço urbano, para cuja efetivação as estratégias das empresas do setor imobiliário são primordiais. Com isso em vista, o trabalho utilizou o conceito de fronteira urbana para aprimorar o entendimento das estratégias de valorização do espaço, verificando como esse processo se consumou no empreendimento Jardim Europa, localizado no setor leste da cidade de Porto Alegre. Colocou-se em evidência o fato de que as empresas do setor imobiliário esforçam-se constantemente por integrar áreas menos valorizadas à esfera de circulação de seu capital, com o intuito de obter sobrelucros de incorporação. Para atrair segmentos das classes média e alta para áreas menos valorizadas da cidade, as empresas lançam mão de publicidade maciça, vendendo signos do bemestar e da harmonia com a natureza, bem como procuram apoiar-se no Estado, que frequentemente respalda suas iniciativas. O resultado é a permanente remodelação do espaço urbano sob a égide da acumulação de capital, o que conduz à reiteração das distâncias sociais e espaciais entre os centros valorizados e as vastas periferias urbanas características do capitalismo brasileiro.

PALAVRAS-CHAVE: Fronteira urbana; desenvolvimento desigual; neoliberalismo; centralidades urbanas. 


\begin{abstract}
SANFELICI, Daniel de Mello. The production of space as a commodity: new areas of real estate development in Porto Alegre/RS. 2009. 145f. Dissertação (Mestrado) - Faculdade de Filosofia, Letras e Ciências Humanas. Universidade de São Paulo, 2009.
\end{abstract}

The current research attempted to reveal the central aspects of the production of the metropolitan space of Porto Alegre during the last 15 years. First of all, we established the theoretical framework which helped us understand the movement that transforms space into a commodity. This has allowed us to demonstrate how this transformation has been occurring in Porto Alegre and how it has given rise to new spatial centralities in terms of real estate development. This is a process largely carried out by business strategies devised by large real estate developers. Having this in view, we made use of the concept of urban frontier in order to enrich our understanding of the business strategies of real estate development, paying attention to the changes occurred with Jardim Europa, a large development project located in the Eastern part of Porto Alegre. We emphasized the fact that large developers strive to incorporate areas of lower land prices into the sphere of circulation of their capital with the aim of obtaining surplus development profits. So as to attract middle and upper class households to these frontiers, developers employ massive advertising campaigns, selling signs of welfare and of harmony with nature, at the same time as they rely on the local state, which usually supports their development schemes. The result of this is the restless refashioning of urban space carried out by capital accumulation, thus leading to the reinforcement of the social and spatial distances that separate the gentrified neighborhoods and the vast urban peripheries typical of capitalism as it has developed in Brazil.

KEY-WORDS: Urban frontier; uneven development; neoliberalism; urban centralities. 


\section{LISTA DE TABELAS}

Tabela 1 - Cargos públicos e privados dos acionistas da Cia. Predial e

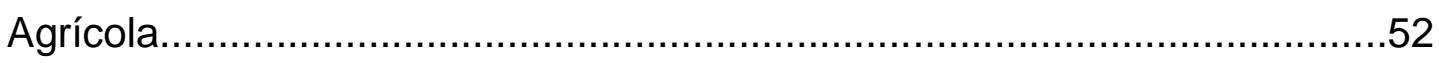

Tabela 2 - Porcentagem da oferta acima de 300 mil reais em 2007................64

Tabela 3 - Média de unidades por empreendimento em 2006 e 2007 .............72

Tabela 4 - Rendimento médio domiciliar em 2000 .....................................98

Tabela 5 - Atuação de empresas com escala nacional no mercado

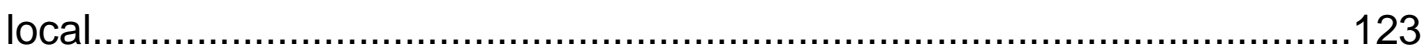




\section{LISTA DE MAPAS}

Mapa 1 - Bairros oficiais do município de Porto Alegre. 19

Mapa 2 - Rendimento mensal médio dos responsáveis pelo domicílio em Porto Alegre (2000) 66

Mapa 3 - Preço médio, em reais, de um apartamento (usado) de 3 dormitórios em Porto Alegre .67

Mapa 4 - Bairros de rendimento familiar superior em Porto Alegre .68

Mapa 5 - Porcentagem de imóveis novos acima de $\mathrm{R} \$ 300$ mil em Porto Alegre/RS. 69

Mapa 6 - Densidade de ofertas por bairro em Porto Alegre (2005).................76

Mapa 7 - Densidade de ofertas por bairro em Porto Alegre (2007).................77

Mapa 8 - Unidades vendidas por bairro entre março de 2006 e dezembro de 2007 .78

Mapa 9 - Atividades imobiliárias de grandes empresas do setor em Porto Alegre. 82

Mapa 10 - O Parque Germânia e a área do entorno dos shoppings Iguatemi e Bourbon. 92 


\section{LISTA DE FIGURAS E GRÁFICOS}

Gráfico 1 - Evolução da população residente em Porto Alegre (18902006)

Figura 1 - Evolução urbana do município de Porto Alegre. .55

Gráfico 2 - Unidades lançadas no mercado imobiliário de Porto Alegre durante a década de 1980.

Gráfico 3 - Área média dos imóveis ofertados em Porto Alegre $\left(\mathrm{em} \mathrm{m}^{2}\right)$ na década de 1980

60

Gráfico 4 - Tipologia da oferta imobiliária em Porto Alegre na década de 1980

Gráfico 5 - Número de lançamentos e número de vendas no mercado imobiliário de Porto Alegre - 1994-2006

Gráfico 6 - Velocidade média anual de venda no mercado imobiliário de Porto Alegre (\%). 62

Gráfico 7 - Distribuição das ofertas acima de $R \$ 705$ mil em 2007 .70

Figura 2 - Edifícios situados em frente ao shopping Iguatemi construídos durante a década de 1990 . 99

Figura 3 - Primeiros edifícios do empreendimento em vias de finalização, vistos a partir da Rua Tremembé (junho de 2008). 101

Figura 4 - Vista do Jardim Europa a partir do estacionamento do Shopping Iguatemi (Junho de 2008) 102

Figura 5 - Vista parcial do parque e dos primeiros edifícios em processo de finalização (Junho de 2008). 102

Figura 6 - Anúncio publicitário da Goldsztein sobre o Jardim Europa. 103

Figura 7 - Projeto original do loteamento Germânia (2001)..........................104

Figura 8 - Anúncio publicitário do Jardim Europa (1)..................................107

Figura 9 - Anúncio publicitário do Jardim Europa (2).................................108

Figura 10 - Anúncio publicitário do Jardim Europa (3)................................113

Figura 11 - Reportagem do jornal Zero Hora sobre a inauguração do Parque Germânia

Figura 12 - Vista parcial da Avenida Carlos Gomes, em Porto Alegre. 129

Figura 13 - Vista de trecho da Avenida Carlos Gomes. 129 


\section{SUMÁRIO}

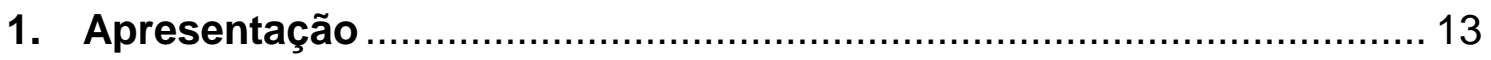

2. Elaborando um problema.................................................................... 17

3. Das contradições no espaço às contradições do espaço: o lugar do imobiliário na geografia econômica da cidade capitalista .......................... 35

4. A espacialidade da valorização capitalista: um panorama dos movimentos espaciais do capital imobiliário na evolução recente da

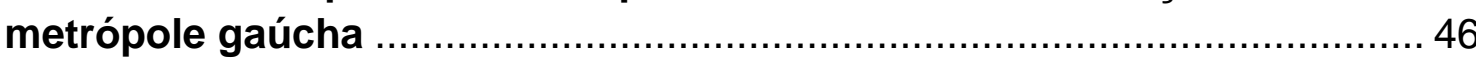

5. O significado das fronteiras urbanas na produção do espaço da metrópole: o Jardim Europa como nova centralidade de valorização

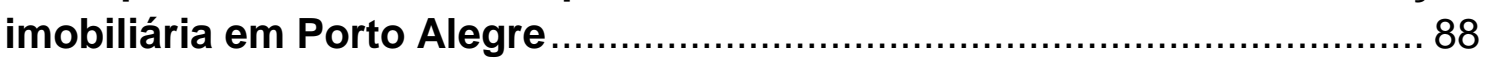

5.1. O shopping Iguatemi como propulsor inicial da valorização .................. 96

5.2. O empreendimento Jardim Europa: natureza do projeto ..................... 100

5.3. O Parque Germânia como estratégia de valorização: a "autenticidade" como criação da publicidade ............................................................... 106

5.4. Risco e sobrelucro no investimento em fronteiras urbanas ............... 115

5.5. A expansão da malha viária do Corredor de Centralidade Nilo Peçanha-

Anita.

5.6. A concentração do poder econômico como necessidade para a obtenção de lucros de incorporação

6. Estado, circuito secundário e consumo dirigido: considerações finais sobre a produção do espaço da metrópole sob o signo do

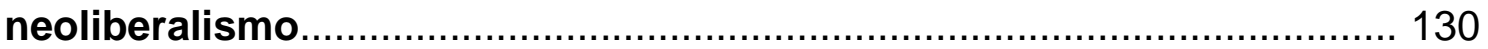

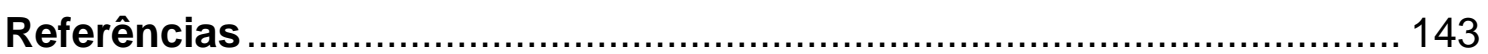




\title{
1. Apresentação
}

Em certo momento no conjunto de ensaios publicado sob o título de "História e consciência de classe", Georg Lukács observa que

\begin{abstract}
pensamento e ser são idênticos não no sentido de corresponderem ou "refletirem" um ao outro, de "correrem paralelamente" entre si ou "convergirem" (...), mas no fato de constituírem aspectos de um único processo dialético, histórico e real (LUKACS, 2003, p. 403).
\end{abstract}

Com isso, Lukács punha em evidência o fato de que a reflexão, confrontada constantemente com uma realidade fluida, em movimento, deve 0 tempo todo superar-se se deseja superar o imediatismo com que essa realidade em movimento aparece aos olhos da prática cotidiana de todos. Sem dúvida, isso levanta uma série de obstáculos ao pesquisador, não somente pelo fato de que é preciso que sejam construídas as mediações imprescindíveis para que se possa ter o acesso ao conteúdo subjacente às manifestações imediatas da realidade, mas ademais porque essa realidade sói mover-se mais velozmente do que a nossa capacidade de apreendê-la. Resulta disto que, no período compreendido pela pesquisa de Mestrado, muitas coisas que apareciam como irrelevantes no início mostram-se, com o tempo, cruciais, enquanto outras que pareciam fundamentais enfraquecem-se como fator explicativo. Em se tratando de uma realidade em movimento, não é por completo possível de evitar que isso aconteça, mas deve-se ater firmemente ao princípio de que, se entendemos a realidade não como um conjunto de fatos dados e estanques, mas como um conjunto contraditório de processos e relações, devemos ter como meta a tentativa de revelar o conteúdo desses processos e a direção para a qual eles nos encaminham. Somente assim será possível discernir entre o fundamental e o irrelevante, e, sobretudo, entender que o fundamental está no acesso à totalidade em movimento, na compreensão do processo total que se manifesta contraditoriamente em cada aspecto que compõe o conjunto da realidade. Em nosso entendimento, seguindo Henri Lefebvre, residem na renúncia à compreensão da totalidade as maiores fraquezas das ciências sociais hoje, fragmentadas em uma miríade de especialidades com métodos e procedimentos de investigação próprios e sem contato com outros campos do saber. 
O caminho aqui percorrido foi norteado, portanto, por esse princípio, e seu objetivo, apresentado em maiores detalhes no primeiro capítulo, foi compreender alguns dos processos que são responsáveis pela produção do espaço das metrópoles no atual estágio da sociedade capitalista. Cabe aqui fazer algumas advertências.

Em primeiro lugar, é preciso ser dito que foi intencional a colocação de um capítulo eminentemente teórico no início da exposição. Acreditamos que as considerações apresentadas no capítulo, e que se referem fundamentalmente ao domínio quase completo que a forma-mercadoria exerce sobre todas as manifestações da vida social hoje, permeiam todas as reflexões posteriores do trabalho, e isto pode ser observado em outros momentos do trabalho. Tendo isso em vista, entendemos ter sido necessário apontar algumas das contradições que esse processo de mercantilização da vida cotidiana e da cidade carrega. Todavia, como será visto, a colocação de um capítulo mais teórico no início não significou uma separação rígida das considerações teóricas e das empíricas, procedimento muito recorrente hoje do qual discordamos.

Em segundo lugar, é preciso ser dito que um dos momentos mais difíceis da dissertação foi encontrar sólidas evidências empíricas para sustentar a hipótese inicial, o que, por um caminho ou por outro, acreditamos ter conseguido. Mas é fato que, no Brasil de hoje, tem sido cada vez mais difícil para uma pesquisa se apoiar em dados e levantamentos estatísticos, visto que estes são cada vez mais pobres e mesmo sequer são realizados, para a maioria das áreas de estudo. As pesquisas, por exemplo, que conseguimos obter, depois de uma insistência quase impertinente, junto ao Sinduscon e a empresários do setor imobiliário ainda se revelam muito pobres quanto ao conjunto de aspectos abrangidos. Nada se pode obter, nessas pesquisas, sobre a atividade de cada empresa individual, nem mesmo das maiores, sobre a localização dos investimentos - a não ser um total de unidades lançadas por bairros que utilizamos durante o trabalho - e não há nem mesmo um histórico minimamente consistente da atividade imobiliária na cidade. Dados de empresas individuais como número total de unidades lançadas, tipologia dos lançamentos e preço final das unidades inexistem. O Município, por sua vez, não oferece qualquer informação que possa compensar essa deficiência, e 
mesmo o dado de número total de Habite-se deixou de ser especificado, como o era, de acordo com o número de pavimentos das habitações. Ainda outro obstáculo para a presente pesquisa refere-se ao fato de que a planta de valores do município, que serve de base para a cobrança do imposto territorial, não é atualizada desde 1992, o que inviabilizou sua utilização nesse trabalho. Sua transformação em mapa, ademais, requereria muito mais tempo do que seria possível no contexto dessa pesquisa. Enfim, não é intenção aqui de atribuir qualquer insuficiência ou interpretação errônea do trabalho a esta falta de informações, mas sim lamentar essa situação que, se modificada, poderia oferecer melhores condições para inúmeras pesquisas que desejam compreender esta atividade que, hoje, revela-se tão importante na estruturação do espaço das metrópoles, e compreender, de maneira mais geral, os problemas urbanos atuais.

Essa adversidade soma-se a outra, que se refere à dificuldade de obter informações mais precisas das atividades das empresas, algumas vezes por uma indisposição da empresa e/ou de alguns de seus funcionários em reservar um tempo para uma entrevista ou responder perguntas, mesmo por e-mail. Embora saibamos que, para uma empresa capitalista, o emprego racional do tempo é fundamental, e que, portanto, uma entrevista que não seja destinada a uma divulgação mais ampla nenhuma importância possui do ponto de vista da maximização dos ganhos da empresa, a diversidade das respostas permite-nos sugerir que houve, em muitos casos, explícita má vontade, por parte de certas empresas e/ou pessoas, em cooperar com uma pesquisa acadêmica, se compararmos com a solicitude apresentada por outras. Nesse sentido, é preciso lamentar a estreiteza da visão de certas empresas a respeito das possibilidades de cooperação com as pesquisas realizadas pela universidade em qualquer área do conhecimento.

É oportuno relativizar também nossa opção por tratar dos problemas da cidade de Porto Alegre, sem uma atenção mais cuidadosa ao conjunto da metrópole. Ela não representa uma tentativa de autonomização, de tratamento da capital gaúcha de maneira independente do conjunto da metrópole, o que, em nosso ver, é um equívoco, visto que, apesar das divisões administrativas, a metrópole constitui uma totalidade inseparável e cujos problemas só podem ser resolvidos se for tratada como tal. A necessidade de circunscrição da pesquisa 
à capital, unicamente, deve-se, em primeiro lugar, à dificuldade sempre maior de se obter informações sobre os outros municípios da metrópole no que se refere à dinâmica imobiliária; por outro, deve-se, por motivos bastante óbvios, às restrições de tempo que pesam sobre uma pesquisa de Mestrado. Mas a dinâmica imobiliária que identificaremos na capital gaúcha revela-se, com efeito, no conjunto da metrópole, cuja evidência mais imediata reside no fato de que várias das grandes empresas trabalhadas aqui investem também em outras centralidades imobiliárias de uma metrópole que é hoje, certamente, polinucleada. É preciso frisar, ainda, que muitos dos investimentos realizados em outros municípios estão intimamente ligados à dinâmica de empregos da capital, como o condomínio Alphaville em Gravataí, ainda em estágio inicial e que usufruirá de acesso rápido a Porto Alegre pela rodovia Free way. 


\section{Elaborando um problema}

Le monde à la fois présent et absent que le spectacle fait voir est le monde de la marchandise dominant tout ce qui est vécu. Et le monde de la marchandise est ainsi montré comme il est, car son mouvement est identique à l'éloignement des hommes entre eux et vis-à-vis de leur produit global

Guy Debord

Quelle aubaine, l'espace! II se vend et s'achète. II étend le monde de la marchandise. En même temps, il permet de contrôler les forces sociales qui pourraient s'opposer au pouvoir politique établi.

Henri Lefebvre

O presente trabalho pretende lançar luz, através de um estudo de caso, sobre a produção de um espaço da acumulação capitalista na cidade de Porto Alegre. Ao longo das páginas que se seguem, buscar-se-á compreender a produção de uma espacialidade (e temporalidade) da cidade, no último decênio, a partir do desdobramento da atividade de um setor específico da produção capitalista de mercadorias: o setor imobiliário habitacional. A motivação que justifica a perseguição desse caminho surge, em primeiro lugar, de uma constatação da proeminência adquirida pelo capital imobiliário na constituição de novas (e reafirmação de antigas) centralidades espaciais na metrópole de Porto Alegre, reconfigurando os ordenamentos espaciais pretéritos de forma a torná-los consentâneos às necessidades da valorização do capital. Esse movimento de rearranjo da espacialidade da metrópole, em larga medida sob a égide do mercado imobiliário, é repleto de simultaneidades e descompassos, continuidades e intermitências, mas encaminha-se, fundamentalmente, na direção da consolidação de eixos de valorização imobiliária discerníveis na paisagem urbana, no interior dos quais estão 
colocadas as maiores possibilidades de rentabilidade à disposição do capital investido no ambiente construído. Na metrópole gaúcha, esse movimento de constituição de novas centralidades da valorização imobiliária orienta-se no sentido da solidificação de dois grandes eixos distinguíveis: um eixo centroleste, cuja orientação é dada pelo traçado estabelecido, grosso modo, pelas radiais Protásio Alves, Nilo Peçanha e 24 de outubro; e um eixo centro-sul, que acompanha longitudinalmente a borda do lago Guaíba. A constituição desses eixos é um processo inacabado e alimentado por ciclos de investimento que se concentram no tempo e no espaço, permitindo que identifiquemos, de forma mais ou menos precisa, alguns padrões de investimento imobiliário na paisagem metropolitana sustentados, mormente, por estratégias de curto e médio prazo. Nesse âmbito, os anos recentes testemunham, para o caso de Porto Alegre, algumas tendências relativamente nítidas: uma que colocou o bairro Cristal, na zona sul da cidade, no centro dos interesses especulativos imobiliários, principalmente em razão da construção da III Perimetral, que ampliou a acessibilidade à região como um todo, e do anúncio da construção de um novo shopping na região próxima ao Jóquei clube; a outra, no eixo centro-leste, que reafirma a centralidade do shopping center Iguatemi a partir de um conjunto de investimentos (comerciais e residenciais) em uma escala sem precedentes para o caso da metrópole gaúcha ${ }^{1}$. Essa última tendência principalmente no que diz respeito à comercialização do Jardim Europa, um novo "bairro" nos arredores do Iguatemi - servirá como perspectiva, na segunda parte do trabalho, para que possamos compreender as estratégias que se entrelaçam na constituição dessas novas centralidades imobiliárias. Algumas considerações preliminares são, contudo, necessárias para situar melhor o sentido da pesquisa. Apresentamos, ademais, inicialmente um mapa em anexo (Mapa 1) situando os bairros da capital gaúcha, que daqui para diante serão mencionados em vários momentos do texto.

\footnotetext{
1 Simultaneamente a essas duas tendências, persistem os investimentos nos bairros mais tradicionais da cidade, sobretudo aqueles com área passível de incorporação, como é o caso dos bairros Petrópolis e Menino Deus, que apresentam o maior número de unidades ofertadas em 2007.
} 


\section{Bairros do município de Porto Alegre}

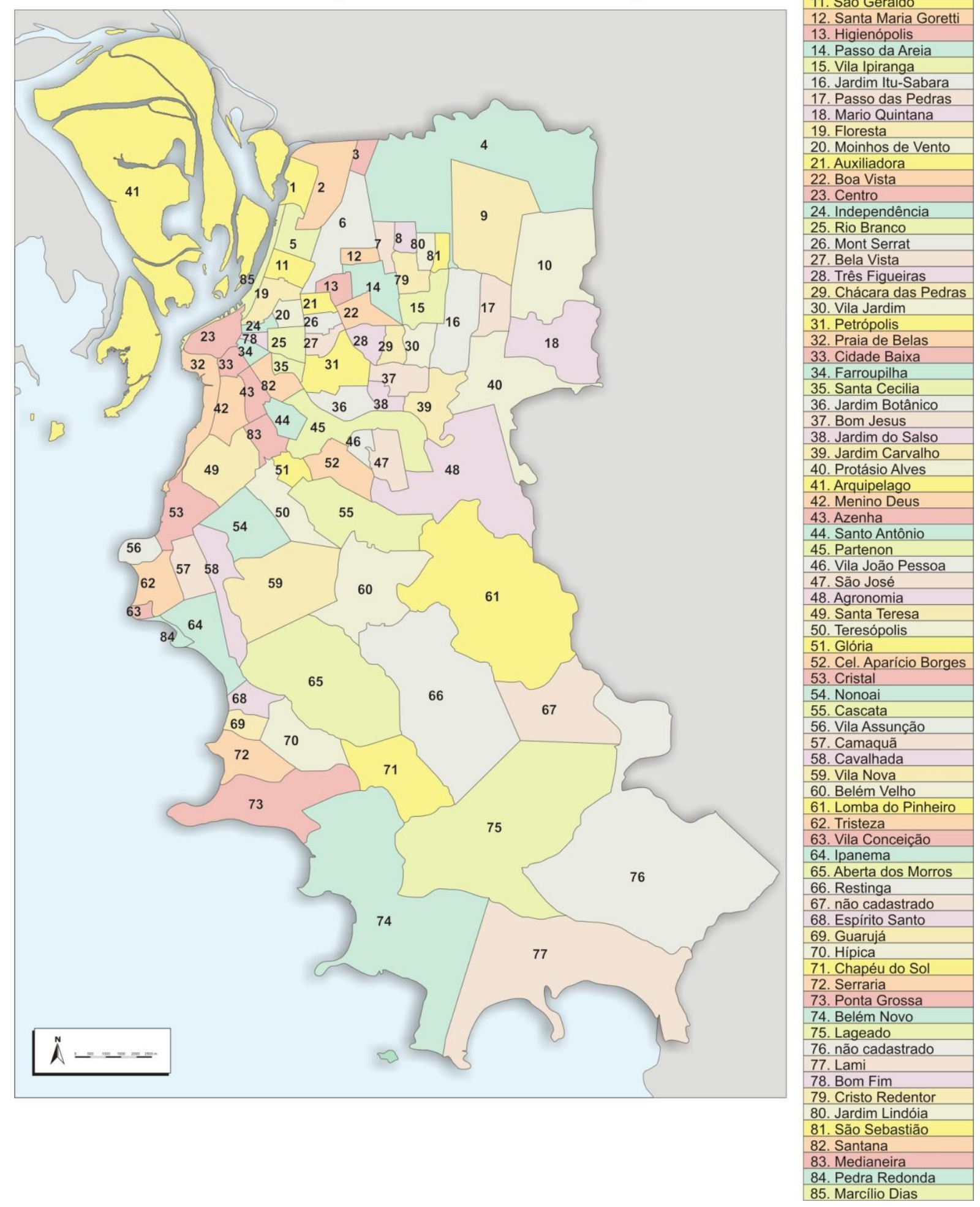

Mapa 1 - Bairros oficiais do município de Porto Alegre/RS. 
A complexidade do objetivo aqui buscado - o de compreender 0 movimento de reprodução do espaço urbano a partir do desdobramento da atividade imobiliária - revela-se imediatamente pelo fato de que se trata de um setor cujas particularidades são em si evidentes, se comparado com outros setores da produção capitalista. Não só este setor, cujo desenvolvimento é o objeto do nosso estudo, tem como pressuposto de sua própria realização, a realização da propriedade fundiária - o que coloca para o pesquisador problemas, entre outros, como o da renda da terra e de uma produção estatista do espaço urbano -, mas também tem como seu produto uma mercadoria que difere muito das outras, quer seja pelo seu valor elevado - o que coloca, de imediato, o problema do crédito -, quer seja pela sua fixidez no espaço e sua existência prolongada - o que remete à questão das valorizações e desvalorizações a que o espaço está sujeito ao longo dos anos, bem como ao problema da circulação do capital fixo. Outras peculiaridades do segmento em estudo serão evidenciadas no decorrer da exposição. $O$ trabalho, que fique advertido, não tem a pretensão (nem seria possível no espaço de tempo que constitui tal pesquisa) de contemplar todos estes aspectos de forma satisfatória. Entretanto, pretende trazer alguns apontamentos que permitam compreender a produção do espaço da cidade de Porto Alegre sob as determinações do movimento de valorização do capital. O espaço, nesse movimento, é materialidade, mas também é veículo (meio) da realização do valor e da mais-valia, portador de determinações formais. Sua materialidade entra, portanto, no âmbito dessa pesquisa, acima de tudo na medida em que interfere na valorização do capital. O mesmo vale para outras determinações cuja importância é inegável (por exemplo, a atuação do Estado), mas que só serão abordadas quando e na medida em que necessárias para a compreensão do movimento de valorização (e de desvalorização) do espaço e do capital produzindo o espaço. $O$ acento no problema da valorização do capital como eixo interpretativo das mudanças espaciais a que estão submetidas as cidades, e mais particularmente, a cidade de Porto Alegre, não deve significar uma abordagem que negligencie os conflitos e as estratégias elaboradas pelos sujeitos que, de uma forma ou de outra, adquirem consciência do processo em que estão inseridos e atuam no sentido de direcionar os rumos tomados pelo processo. Uma abordagem, portanto, que 
coloca em relevo única e exclusivamente os automatismos fetichistas do movimento de valorização do capital perde de vista as estratégias que se põem em marcha a partir do momento em que os sujeitos envolvidos adquirem consciência (mesmo que limitada) de seu campo de atuação e agem no sentido de moldar um futuro ainda desconhecido ${ }^{2}$. O político e o econômico, dimensões que somente a sociedade burguesa separou em duas esferas com aparência de autonomia, inevitavelmente se entrelaçam como parte do processo de valorização capitalista do espaço ${ }^{3}$. Trata-se, então, de compreender essa geografia de contornos díspares e as contradições que assomam a partir desse complexo processo produtivo do espaço.

O caminho aqui perseguido parte de um entendimento, portanto, de que cada vez mais o espaço, e especificamente aqui o espaço urbano, realiza-se como mercadoria. Isso significa dizer que cada vez mais são os imperativos da realização do valor (e da mais-valia) que se antepõem, como pressupostos, ao uso do espaço. A redução da diversidade do espaço à forma-valor significa uma incomensurável homogeneização do espaço, uma redução da diversidade a uma medida comum: o trabalho abstrato manifestado na forma-valor. Mas significa também, e contraditoriamente, uma fragmentação, na medida em que o espaço é vendido em parcelas, em pedaços, e para tanto é dividido ${ }^{4}$. Se o uso, ou valor de uso, cada vez mais se apaga frente ao império do valor de

\footnotetext{
${ }^{2}$ Parece ser esta uma diferença fundamental que existe entre abordagens como as de Guy Debord e Henri Lefebvre e aquelas desenvolvidas, por exemplo, pelo grupo Krisis. Tanto Guy Debord quanto Henri Lefebvre teorizam a respeito da imensa reificação a que estão sujeitos os indivíduos nessa sociedade em que ocorre o movimento autônomo do dinheiro e do valor, movimento esse que escapa, em grande medida, à possibilidade de controle por parte desses indivíduos. Mas nem por isso esses autores deixam de identificar o momento ativo da atuação dos sujeitos (Lefebvre através de sua insistência na existência de estratégias e táticas, e Debord trazendo mais nitidamente a questão da luta de classes). As análises do grupo Krisis parecem negligenciar a possibilidade de atuação do sujeito nos conflitos potencialmente colocados pelo movimento do capital. Uma análise da conjuntura como o momento do emprego de estratégias e táticas no sentido de modelar um futuro ainda desconhecido e sobre o qual se constroem expectativas diversificadas pode ser encontrada em Fiori (2003, cap. 1). Ainda sobre a questão das estratégias, cabe uma citação de Lefebvre que explicita o que o autor entende que deva ser uma economia política do espaço: "L'économie politique de l'espace est bien une économie impliquant une politique, à savoir une stratégie ou plusieurs stratégies" (2000b, p. 125). Tradução: "A economia política do espaço é uma economia que implica uma política, a saber, uma estratégia ou inúmeras estratégias". Tradução nossa.

3 "(...) a proposta é que se pense o Estado como dimensão do capital em geral e a valorização como um processo econômico e político, a um só tempo" (FIORI, 2003, p. 106). A regulação do câmbio por parte do Estado é um dos momentos em que há um forte entrelaçamento do econômico e do político, um dos aspectos tratados pelo autor nessa obra.

${ }^{4}$ Essa contradição foi apontada diversas vezes por Lefebvre (1978; 2000a; 2000b).
} 
troca, então o uso do espaço também se submete cada vez mais às prescrições estabelecidas pelo valor de troca. Essa mercantilização progressiva do espaço, que se transmuta cada vez mais em bem "mobiliário", parece ser parte, contudo, de um movimento incessante do capitalismo no sentido de encontrar novos campos de acumulação, novas fronteiras, para evocar Neil Smith, para a realização do valor e da mais-valia. Discorreremos brevemente sobre isto antes de um retorno aos problemas específicos postos pelo setor imobiliário e pela investigação que aqui se pretende desenvolver.

Uma das características mais distintivas do capitalismo, quando comparado com outros modos de produção, é seu impulso expansionista. Premido por uma tendência à saturação dos mercados (sobreacumulação) e conseqüente queda da lucratividade, o capital deve procurar novos espaços de acumulação ${ }^{6}$. O que o decorrer da história do capitalismo até esse início de século deixou evidente é que esses novos espaços de acumulação podem ter origens variadas, sendo o recurso ao comércio exterior com regiões nãocapitalistas, aspecto sobrevalorizado por Rosa Luxemburgo, apenas uma das soluções para a sobreacumulação. Nem todas as soluções (sempre temporárias) para esse problema se encontram na incorporação de áreas e setores não-capitalistas, mas o século $X X$ tornou evidente a imensa capacidade do capitalismo de incorporar esferas inteiras da vida social ao circuito da valorização do capital. Combinaram-se, então, uma expansão absoluta do capital para regiões ainda não inseridas na divisão do trabalho e um avanço da produção capitalista (e, portanto, da lógica da mercadoria) para esferas da vida social antes não plenamente submetidas à valorização capitalista. Essa última forma de expansão parece ter ganhado vigor nos últimos anos, dando sentido à preocupação de Guy Debord com uma tendência à colonização da vida cotidiana pela forma-mercadoria. Também aí ganham clareza as constatações e críticas de Henri Lefebvre a respeito da inserção do lazer e do turismo na divisão do trabalho e na produção de mercadorias (LEFEBVRE, 2000a, p. 71-2; 2002, p. 80). Essas múltiplas e variadas formas

\footnotetext{
${ }^{5}$ Cf. Lefebvre (2003b). O tratamento que Harvey (1999) concede à renda da terra como uma forma de capital fictício vai nesse sentido de esclarecer as determinações de um espaço que se transforma, cada vez mais, num ativo financeiro.

${ }^{6}$ Os últimos 30 anos recolocaram o problema da sobreacumulação na reprodução do capital mundializado. Cf. Brenner, R. (2003).
} 
de acumulação por expropriação, para usar os termos de $\mathrm{Harvey}^{7}$, se combinam permanentemente com a reprodução ampliada dos ramos já consolidados da produção capitalista.

Ao longo do século $X X$, e com intensidade maior no final do mesmo século, uma das esferas da vida social em que o processo de mercantilização mais avançou foi a esfera cultural, cuja lógica de funcionamento fora, em alguma medida, independente, ou ao menos um pouco mais distanciada, da lógica que rege a produção de mercadorias sob o capitalismo moderno. Um trabalho importante como "A dialética do esclarecimento", de Theodor Adorno e Mark Horkheimer (1985), já indicava, através do conceito de indústria cultural, um processo que se intensificaria no período que tem sido denominado "pósmoderno". Esta nova "fronteira" para investimentos conferiu novo impulso à acumulação capitalista, como o atesta, por exemplo, o fato de que os filmes de Hollywood são, hoje, itens de primeira importância na pauta de exportações dos Estados Unidos. Fredric Jameson nota que

\begin{abstract}
[...] em uma era anterior, a arte era uma esfera além da mercantilização, na qual uma certa liberdade ainda era possível; no modernismo tardio, no ensaio de Adorno e Horkheimer sobre a indústria cultural, ainda havia zonas de arte isentas da mercantilização e da cultura comercial (para eles, essencialmente Hollywood). Por certo, o que caracteriza a pós-modernidade na área cultural é a supressão de tudo o que havia de exterior à cultural comercial, a sua absorção de todas as formas de arte, altas e baixas, junto com a própria produção de imagens (JAMESON, 2006, p. 216).
\end{abstract}

Algumas das conseqüências do desenvolvimento deste novo "setor" da acumulação capitalista parecem se enraizar com maior profundidade nas metrópoles atuais.

Sharon Zukin inicia seu livro The Cultures of the Cities afirmando que "[...] culture is more and more the business of cities - the basis of their tourist attractions and [...] their competitive edge" (ZUKIN, 1995, p. 2) $)^{8}$ para, em seguida, identificar o surgimento do que denominou de "economia simbólica", um complexo de negócios que reúne entretenimento, turismo, gastronomia e produção cultural e que tem sido responsável por transformações significativas na paisagem urbana. No centro desta economia transformada estaria a

\footnotetext{
${ }^{7}$ Cf. Harvey (2003)

8 "[...] a cultura é cada vez mais o negócio das cidades - a base de suas atrações turísticas [...] e sua vantagem competitiva". Tradução nossa.
} 
imagem, conforme já havia prenunciado Guy Debord em sua teorização da sociedade do espetáculo ${ }^{9}$. Mas a autora prossegue em sua teorização e expõe a íntima relação que existe entre a instalação desta indústria na cidade (museus, restaurantes, hotéis, teatros) e a valorização imobiliária, numa escala menor, e a importância desta economia simbólica na projeção das cidades na economia nacional e global, em uma escala mais ampla. Enquanto parece não ser difícil identificar uma progressiva mercantilização da cultura no Brasil na segunda metade do século $X X^{10}$, a importância desta economia simbólica na transformação da paisagem urbana no Brasil não parece ser, à primeira vista, tão nítida, sobretudo se for feita a comparação com a sociedade estadunidense, foco dos estudos realizados por Sharon Zukin. Mas o processo também se verifica no Brasil. Em uma escala mais abrangente, torna-se cada vez mais evidente que certas cidades têm prosperado ao conseguir tirar proveito (vendendo como mercadoria) de especificidades histórico-culturais ou naturais (os exemplos são muitos, desde Paraty (RJ) até Bonito (MS)). Outras cidades conseguem até mesmo criar estas especificidades, desenvolvendo um complexo de turismo gastronômico e de consumo que não se nutre, necessariamente, de uma tradição cultural bem definida ou de um passado histórico singular (Gramado (RS) parece ser um exemplo típico). Mas em uma escala menor, percebe-se também que a cultura tem sido usada como indutora de um processo de valorização imobiliária: em muitos dos projetos de "revitalização" dos centros das metrópoles brasileiras está presente a idéia de que a instalação de cinemas, teatros e restaurantes nestas áreas pode induzir a um processo de recuperação do valor das propriedades, solucionando o problema da "decadência" dos centros. Fica evidente, então, a maneira como os discursos sobre a cultura e o consumo cultural se apresentam como propulsores de uma valorização do espaço que culmina, em muitos casos, em uma gentrificação, processo já descrito e estudado por muitos autores ${ }^{11}$. O fato

\footnotetext{
${ }^{9}$ Cf. Debord (1992)

${ }^{10}$ A este respeito, é fundamental a contribuição de Renato Ortiz (1994), que reconstitui historicamente este processo pelo qual a cultura, no Brasil, foi se submetendo cada vez mais aos imperativos de mercado, processo que, embora iniciado no início do século XX, só se consolidou em definitivo a partir dos anos 50 e, com maior vigor, durante os anos 70 .

${ }^{11}$ O papel importante que a cultura adquire na valorização do espaço não invalida a relevância de uma desvalorização pretérita do espaço para que ganhe impulso a revalorização. É disto que pretende dar conta o conceito de rent gap em Neil Smith (1996). Também não se pretende aqui defender a idéia de que a desvalorização ocorre porque é funcional à
} 
de que esta estratégia, no Brasil, não tem trazido todos os resultados almejados em nada altera o papel que se deseja que as atividades culturais cumpram $^{12}$.

Um elemento não menos importante deste processo, e que deve ser ressaltado, é que a mercantilização da cultura tem significado, nos anos recentes, uma estetização da diferença cultural realizada como objeto de consumo. A diferença cultural se torna simulacro, imagem da diferença, objeto reproduzido como consumo ${ }^{13}$, num mundo que, em sua essência, tende para o homogêneo. Não é de se surpreender, portanto, que Slavoj Zizek perceba que a noção contemporânea (liberal) de multiculturalismo esteja, na verdade, calcada na própria universalidade do capital e na homogeneização que o mercado proporciona ${ }^{14}$.

A conclusão parece ser a de que, nos dias de hoje, de predomínio da ideologia (e da prática política) neoliberal, pouco escapa do circuito abrangente da produção e circulação do capital. Lefebvre, por exemplo, aponta em vários momentos de sua obra o surgimento de "novas raridades", advindas do fato de que bens outrora abundantes, como a água, começam a escassear, principalmente em virtude de sua mercantilização ${ }^{15}$. A inserção de muitos desses setores na produção capitalista de mercadorias envolve uma forma ou outra de expropriação, ou de acumulação por expropriação. Não é difícil constatar, por exemplo, como a indústria do turismo destrói modos de vida não compatíveis com a sua reprodução, como é o caso de vilas de pescadores que cedem lugar (compulsoriamente) a complexos hoteleiros e praias exclusivas. No caso da cultura, a apropriação (expropriação) de culturas locais ou folclóricas pela indústria cultural se tornou prática comum e difundida e pouco sucesso têm tido aqueles que tentam enfrentar o poder dessas corporações multinacionais.

Mas se o século XX assistiu a um avanço da lógica da mercadoria por amplas áreas e regiões ainda não "colonizadas" pela produção capitalista,

\footnotetext{
acumulação de capital no futuro, um funcionalismo que Gottdiener (1994), em nosso ver injustamente, atribui a Harvey.

$12 \mathrm{O}$ excelente artigo de Arantes (2000) traça as coordenadas desse movimento que transformou a cultura em alavanca para o crescimento econômico das cidades, em um ambiente de competição interurbana acentuada.

${ }^{13}$ Cf. Carlos (2001b); Damiani (2004).

${ }^{14}$ Cf. Zizek (2005).

${ }^{15}$ Cf. Lefebvre (2000, p. 115-6).
} 
parece ter ficado manifesto o fato de que todos esses avanços significaram, também, a redução do espaço à troca mercantil. A valorização do espaço que resulta, por exemplo, da atividade cultural e do turismo é sinal de que é o próprio espaço que se insere de maneira mais intensa no processo de troca. A atividade produtiva do espaço está no centro, portanto, dessa colonização progressiva da forma-mercadoria. A produção do espaço se consolida, assim, como um dos ramos de significativa importância da economia capitalista, e aparece como uma das soluções para as crises de sobreacumulação identificadas acima, como Lefebvre e, depois de forma mais elaborada, Harvey vislumbraram $^{16}$. A própria urbanização se realiza, cada vez mais, como negócio ${ }^{17}$, de onde resulta o predomínio de um espaço abstrato, racionalizado, homogêneo, e ao mesmo tempo fragmentado, consentâneo, portanto, às necessidades da reprodução da sociedade mercantil-capitalista ${ }^{18}$. Nesse contexto, é conveniente lembrar a observação de Georg Lukács de que "a extensão da troca mercantil como forma dominante do metabolismo de uma sociedade não pode ser tratada como uma simples questão quantitativa" (LUKACS, 2003, p. 195), pois envolve uma transformação qualitativa muito expressiva.

A identificação do espaço como núcleo desse processo de redução da sociabilidade aos imperativos da valorização mercantil é que permite, portanto, buscarmos na atividade imobiliária alguns dos nexos determinativos da sociedade capitalista em sua fase atual. Trata-se de um setor que se consolida na produção de mercadorias não mais como um ramo atrasado (ainda que

\footnotetext{
${ }^{16}$ Tanto Lefebvre (2000) quanto Harvey (1999) denominam circuito secundário a produção do espaço-mercadoria, denominação que utilizamos algumas vezes no trabalho. Para Harvey (1999), que avançou consideravelmente em relação às considerações bastante iniciais de Lefebvre a esse respeito, quando ocorre sobreacumulação no circuito primário (produção de bens de consumo), o capital tende a se deslocar para a produção do espaço (capital fixo). 0 autor insere de forma mais rigorosa, portanto, a produção do espaço na crítica da economia política de Marx, atentando para a sujeição do espaço às determinações formais do capital. Daí o tratamento que o autor concede à renda da terra como uma forma de capital fictício. Voltaremos ao problema mais adiante.

${ }^{17}$ Cf. Damiani (2005).

18 "Cet espace est homogène parce que tout y est equivalent, échangeable, interchangeable, parce que c'est un espace acheté et vendu et qu'il n'y a échange qu'entre équivalences et interchangeabilités. Cet espace est brisé parce qu'on le traite par lots ou parcelles; vendu par lots ou parcelles, il est donc fragmenté" (LEFEBVRE, 1978, vol. 4, p. 290). "Esse espaço [capitalista] é homogêneo porque nele tudo é equivalente, intercambiável, porque é um espaço comprado e vendido e porque não há troca senão entre equivalências e intercambialidades. Esse espaço é fracionado porque é negociado em lotes ou parcelas; vendido em lotes ou parcelas, ele é, então, fragmentado". Tradução nossa.
} 
persista uma composição orgânica do capital mais baixa), mas como um ramo moderno, cujo capital se encontra cada vez mais centralizado e cuja gestão se assemelha à de outros ramos considerados modernos (ao menos no que diz respeito às empresas de ponta, que abocanham fatias cada vez importantes do mercado imobiliário de metrópoles como Porto Alegre, São Paulo, Rio de Janeiro, etc) ${ }^{19}$.

O que sustenta, portanto, a presente pesquisa é a compreensão de que o capital, ao mesmo tempo em que se realiza enquanto determinação formal, também se realiza em formas concretas que, no caso estudado, conferem à cidade de Porto Alegre sua geografia concreta, seus contornos espaciais mais visíveis. Encontrar os nexos determinativos sem cair na pura abstração, que relega a um distante segundo plano as formas concretas assumidas pelo processo, é um desafio que exige bastante esforço, mas cujo resultado deve se revelar muito mais proveitoso, permitindo-nos compreender a intricada relação que se estabelece entre valor de uso e valor de troca na circulação do capital no ambiente construído e os constrangimentos que esse processo impõe ao espaço vivido e à possibilidade de apropriação efetiva.

Cabem, aqui, algumas considerações sobre escolhas de ordem metodológica e uma melhor delimitação do objeto em estudo, o que exigirá, também, alguns apontamentos mais gerais sobre a especificidade do setor aqui estudado.

Em primeiro lugar, o estudo aqui realizado se limita ao que, no interior abrangente do que poderia se entender como "produção (capitalista) do ambiente construído", ao que se convencionou denominar de setor imobiliário. O foco do trabalho, portanto, é elucidar algumas das determinações capitalistas que, cada vez mais, regem a produção do espaço das metrópoles contemporâneas, sem com isso negar que existam outras formas de produzir o espaço que estão para além dos objetivos do trabalho e que, nem por isso, possuem menor relevância. Nesse caminho, é importante frisar que o Estado, ${ }_{19}$ [O espaço] "está envolvido, enquanto mercadoria, no fluxo mundial de capital, envolvendo
um intricado processo financeiro" (DAMIANI, 2004, p. 6). 
enquanto poder de regulação e de domínio sobre o território, é fundamental para a reprodução do capital, mas sua atuação nem sempre revela um posicionamento monolítico em favor dos interesses hegemônicos do capital, o que abre espaço para pensarmos o Estado como uma arena onde se confrontam interesses divergentes. O Estado, contudo, entra no interesse desse trabalho somente na medida em que sua atuação interfere/direciona/regula a atividade imobiliária. O caminho percorrido é, portanto, o oposto àquele feito por Rovatti (1990), que partiu de uma intervenção do Estado na cidade através dos índices de aproveitamento e, a partir daí, abordou as transformações espaciais resultantes dessa intervenção pública, chegando a interessantes considerações sobre a dinâmica do setor imobiliário ao longo dos anos 80.

Em segundo lugar, é importante salientar que partimos de um entendimento de que produção e circulação são apenas momentos (inextricáveis) do ciclo do capital investido em determinado setor ${ }^{20}$. Sem que sejam cumpridas todas as etapas do ciclo do capital investido, mesmo que sob a tutela de diferentes capitalistas, ocorre uma desvalorização do capital. A forma de abordagem, portanto, deverá incluir todos esses momentos do ciclo do capital investido, mesmo que atores diferentes se consolidem ao se especializar em cada um desses momentos ${ }^{21}$. Partindo desse entendimento, podemos supor que, ao utilizar a denominação "indústria da construção civil", não estaríamos nos referindo unicamente ao processo produtivo em sentido estrito, mas a todos os momentos da rotação do capital investido na produção do espaço, o que incluiria, obviamente, a circulação (e os atores diferentes que, necessariamente, na circulação se especializam). Ainda assim, nos referiremos com mais freqüência ao "setor imobiliário", e isso porque, além do fato de que a expressão é de uso corrente, há claros indícios, ao menos no que se refere à

\footnotetext{
20 "In their actual movement, capitals confront one another in certain concrete forms, and, in relation to these, both the shape capital assumes in the immediate production process and its shape in the process of circulation appear merely as particular moments". (MARX, 1981, p. 117 , v. 3). Em português: "Em seu movimento real, os capitais se enfrentam em formas concretas tais que para elas a figura do capital no processo de produção, assim como sua figura no processo de circulação, só aparecem como fases particulares" (Ed. Civilização Brasileira).

${ }^{21}$ Em suas considerações sobre as peculiaridades do capital comercial, Marx explicita os elos que amarram o capital comercial ao ciclo do capital industrial, dissolvendo a aparente autonomia que o capital investido no comércio e o capitalista que a ele (ao comércio) se dedica adquirem. Cf. Marx, 1980, vol. 3, cap. XVI e XVII.
} 
produção em larga escala, de uma sujeição do processo produtivo da construção aos imperativos da mobilização da propriedade sob a coordenação do capital incorporador e financeiro - mesmo que, se tomado o conjunto do setor, isso ainda se configure apenas como tendência. Obviamente é na produção concreta que se produz o valor e a mais-valia que entram na formação da taxa média de lucro, mas deve-se levar em consideração que no centro da produção imobiliária está a possibilidade de obter sobrelucros de incorporação oriundos da apropriação de renda da terra potencial, o que diferencia o setor de outros. Esse assunto será tratado de forma mais pormenorizada mais adiante.

Em terceiro lugar, o trabalho enfocará com maior ênfase o mercado habitacional vertical, ainda que não dispense considerações necessárias sobre aspectos mais abrangentes da produção da metrópole gaúcha. Duas razões primordiais justificam tal recorte. Uma primeira é de ordem prática. A produção do espaço urbano sob a égide da acumulação capitalista apresenta uma complexidade tal que torna despropositada a pretensão de abordá-la em todos os seus aspectos. Os padrões de localização espacial, por exemplo, que caracterizam os usos do solo para fins comerciais diferem bastante dos padrões que estão na base do mercado imobiliário habitacional. Assim sendo, optamos por privilegiar - e não absolutizar, descolando-o do movimento mais amplo da produção da metrópole - o setor habitacional, em virtude, por um lado, do fato de que o bairro que serviu de recorte para o estudo aqui desenvolvido caracteriza-se por um uso predominantemente residencial e, por outro lado, porque o setor imobiliário para fins residenciais abrange a quase totalidade da produção de imóveis sob a lógica capitalista. Um outro motivo que orientou tal escolha refere-se ao fato de o mercado imobiliário residencial e vertical encontrar-se cada vez mais controlado por um número reduzido de empresas, ao contrário do que acontece, por exemplo, com o mercado de casas, onde a presença do pequeno investidor ainda é grande. Essa delimitação permitiria, então, visualizar de forma mais nítida a presença das grandes corporações na constituição e desenvolvimento do mercado imobiliário da cidade, inclusive apontando para a entrada de investidores de outras regiões no mercado local. Ainda assim, deve-se alertar para o fato de que muitas vezes os dados obtidos não permitiram uma análise mais específica do 
mercado residencial vertical, o que, em nosso ver, não compromete muito os resultados atingidos.

Em quarto lugar, a investigação aqui desenvolvida pretende não perder de vista o desencadeamento de estratégias como parte do movimento do objeto de estudo circunscrito. Conforme exposto brevemente acima, a perspectiva que orienta esse caminho permitiria superar, por um lado, enfoques estruturalistas, que não conseguem vislumbrar a atuação concreta dos sujeitos na determinação da mudança social; e, por outro lado, enfoques excessivamente historicistas, que se equivocam quando não percebem a força da atuação de lógicas abstratas impessoais na condução dos processos sociais, tendência que ganha vigor no período atual de financeirização econômica e penetração da forma-valor nos interstícios mais recônditos da vida em sociedade. Ao lado, portanto, de uma produção lógico-abstrata do espaço, deve-se reconhecer as contradições que surgem do desdobramento de estratégias divergentes, que inevitavelmente se confrontam e produzem resultados diferenciados em cada momento histórico específico. Sobre isso, afirma Lefebvre:

It is not the "élan vital" of the urban community that explains the structures of space [...]. It is the result of a history that must be conceived as the work of social "agents" or "actors", of collective "subjects" acting in successive thrusts, discontinuously (relatively) releasing and fashioning layers of space. These major social groups, comprising classes and fractions of classes, as well as institutions that cannot be adequately defined in terms of class character [...] act with and/or against one another. From their interactions, their strategies, successes, and failures arise the qualities and "properties" of urban space $^{22}$ (LEFEBVRE, 2003, p. 127)

Por fim, faz-se necessário adiantar alguns apontamentos sobre a interpenetração de escalas que toda análise deve contemplar. A investigação levada a cabo no presente trabalho tem como recorte espacial a metrópole de Porto Alegre, hoje entre as cidades economicamente mais importantes do Sul do País. Mas a delimitação desse recorte espacial tem como alicerce um

\footnotetext{
22 "Não é o 'élan vital' da comunidade urbana que explica as estruturas do espaço (...). É o resultado de uma história que deve ser concebida como produto de "agentes" ou "atores" sociais, de "sujeitos" coletivos atuando em sucessivas investidas, descontinuamente (relativamente) liberando e moldando camadas do espaço. Esses grupos sociais principais, que compreendem classes e frações de classes, assim como instituições que não podem ser adequadamente definidas em termos de classe (...), atuam com e/ou contra um ao outro. Das suas interações, estratégias, sucessos e fracassos emergem as qualidades e "propriedades" do espaço urbano". Tradução nossa.
} 
entendimento de que no local se entrelaçam processos cujas escalas se diferenciam significativamente. Nos anos recentes, cada vez mais as cidades são controladas por processos cuja escala de origem está fora de seu alcance (do alcance de seus habitantes e do poder público local), sua margem de manobra consistindo somente na possibilidade de orientar determinados "vetores" externos para determinados fins/objetivos. O surgimento do que seria um "urbanismo neoliberal"23 parece ser a manifestação, na escala local, de processos mais complexos resultantes de uma reconfiguração da acumulação capitalista em favor dos setores rentistas da economia ${ }^{24}$, paralelamente a um remodelamento do Estado para responder a esse novo regime de acumulação fundado na recuperação do poder de classe da elite financeira. Como deverá ficar claro em outros momentos da exposição, essa reconfiguração da acumulação capitalista tem conseqüências imediatas na organização do espaço urbano.

No que tange ao setor imobiliário, objeto de nosso estudo, portanto, devemos contemplar essas escalas diferentes na análise, o que requer no mínimo duas coisas: (1) um entendimento dos caminhos traçados pela economia brasileira nos anos recentes, na medida em que elementos como a trajetória dos juros e do sistema financeiro, do câmbio, o crescimento econômico, a distribuição de renda, etc, interferem nos rumos tomados pela acumulação nesse setor específico; (2) uma apreciação das ações do Estado como agente que altera e direciona os padrões (espaciais) de acumulação no setor em suas múltiplas escalas de atuação. Essa atuação envolve desde a regulamentação de um sistema de financiamento habitacional e do estabelecimento de políticas de habitação, definidas habitualmente em escala nacional, até investimentos no ambiente construído da cidade, que canalizam certos investimentos para determinadas áreas do espaço da cidade, e o estabelecimento de uma legislação urbanística. Obviamente a interferência do Estado não se limita a esses casos, citados apenas a título de exemplo. Também fica evidente que (1) e (2) não podem ser separados senão analiticamente, visto suas influências recíprocas. Em suma, trata-se de lidar com o importante problema, como sugere Villaça, que remete às "mediações

${ }^{23}$ Cf. Merrifield (2002); Hackworth (2007).

${ }^{24}$ Cf. Duménil \& Lévy (2005). 
corretas entre as macrodeterminações socioeconômicas e [...] [o] espaço social, ou seja, as forças sociais que atuam nessas mediações e suas correspondentes formas de atuação" (VILLAÇA, 2001, p. 44). Optamos, todavia, por não separar essa reflexão em um capítulo específico, de maneira que é intenção do trabalho, em toda sua extensão, de construir as mediações entre os movimentos globais da sociedade, em seus múltiplos aspectos, e as formas específicas que a valorização do espaço assume no contexto da metrópole estudada.

Assistiu-se, nos últimos anos, a uma disseminação sem precedentes do discurso dominante (neoliberal) sobre todas as formas de manifestação do pensamento na sociedade brasileira. Mas talvez o que há de mais surpreendente nisso seja o cerco que a razão crítica vem sofrendo no interior da academia e da produção científica nas ciências sociais e humanas, cada vez mais inofensivas no sentido de perturbar a reprodução das relações sociais presentes (quando não há, de fato, uma harmonia plena da produção teórica com as relações dominantes). Este trabalho pretende se inserir em uma tradição teórica (dialética) segundo a qual o pensamento deve expressar contradições existentes na sociedade que é objeto de análise. Nesse sentido, o pensamento que apreende esta realidade contém e expressa uma negatividade que existe, mesmo que potencialmente, na sociedade real. É a presença dessa negatividade que estabelece um divisor de águas entre o pensamento dialético e um pensamento que Herbert Marcuse (2002) denominou unidimensional, preso aos limites estritos da sociedade existente e, por conseguinte, funcional à reprodução dessa sociedade. Os trechos abaixo, extraídos de $O$ homem unidimensional, de Herbert Marcuse, expressam bem essa questão:

The therapeutic and operational concept becomes false to the extent to which it insulates and atomizes the facts, stabilizes them within the repressive whole, and accepts the terms of this whole as the terms of the analysis. The methodological translation of the universal into the operational concept then becomes repressive reduction of thought (MARCUSE, 2002, p. 110-1) . $^{25}$.

E, ainda:

25 "O conceito operacional e terapêutico torna-se falso na medida em que ele isola e atomiza os fatos, estabiliza-os no interior do todo repressivo, e aceita os termos desse todo como termos da análise. A tradução metodológica do conceito universal em conceito operacional torna-se, então, redução repressiva do pensamento". Tradução nossa. Sobre os limites imediatistas das formas de pensamento dominante, cf. também Lukács (2003). 
If dialectical logic understands contradiction as "necessity" belonging to the very "nature of thought" (...), it does so because contradiction belongs to the very nature of the object of thought, to reality (...). Conversely, all estabilished reality militates against the logic of contradictions - it favors modes of thought which sustain the established forms of life and the modes of behavior which reproduce and improve them. The given reality has its own logic and its own truth; the effort to comprehend them as such and to transcend them presupposes a different logic, a contradicting truth. They belong to modes of thought which are non-operational in their very structure; they are alien to scientific as well as common sense operationalism; their historical concreteness militates against quantification and mathematization, on the one hand, and against positivism and empiricism on the other (MARCUSE, 2002, p. 146) ${ }^{26}$.

Por fim, uma advertência de Lefebvre contribui para compreender o papel da dialética enquanto explicitação do movimento contraditório da realidade social, ao mesmo tempo revelando o conteúdo político oculto por detrás de certas abordagens da sociedade:

Certains idéologues se croient capables de séparer par triage la connaissance "pure" de l'ideologie; ils prétendent établir le statut épistémologique du savoir en négligeant le statut social et politique de ce savoir ainsi que celui de la logique. La même démarche evacue le mouvement dialectique et la dialectique comme méthode; on reduit à des contrarietés, voire à de simples contrastes, les rapports dialectiques, ceux de l'échange à l'usage, de la marchandise au travail productif, des rapports de production aux rapports de domination. Ces démarches réductrices ont une portée politique. Bien plus: elles réduisent idéologiquement la connaissance au savoir dominé et dispensé par l'État, par la technocratie et la bureaucratie étatiques. Avec la dialectique on evacue la connaissance critique (LEFEBVRE, 1978, vol. 4, p. 38-9) ${ }^{27}$.

26 "Se a lógica dialética entende a contradição como uma 'necessidade' pertencente à própria 'natureza do pensamento', ela o faz porque a contradição faz parte da natureza própria do objeto do pensamento, da realidade (...). Em oposição, toda realidade estabelecida se opõe à lógica das contradições - essa realidade favorece os modos de pensar que dão suporte às formas de vida estabelecidas e aos modos de comportamento que reproduzem e incrementam essas formas de vida. A realidade dada possui sua lógica e sua verdade próprias; o esforço para compreendê-las como tais e para transcendê-las pressupõe uma lógica diferente, uma verdade que a contradiz. Elas pertencem a modos de pensar que são não-operacionais em sua estrutura; são modos de pensar estranhos ao operacionalismo científico e ao operacionalismo do senso comum; sua concretude histórica se choca, de um lado, com a quantificação e a matematização e, de outro, com o positivismo e o empirismo". Tradução nossa. Negrito nosso. Cf. também Lukács (2003).

27 "Certos ideólogos crêem ser capazes de separar, por triagem, o conhecimento "puro" da ideologia; eles pretendem estabelecer o estatuto epistemológico do saber negligenciando 0 estatuto social e político desse saber, assim como o da lógica. A mesma abordagem esvazia o movimento dialético e a dialética como método; as relações dialéticas, como da troca com o uso, da mercadoria com o trabalho produtivo, das relações de produção com as relações de dominação, são reduzidas a contrariedades, e mesmo a simples contrastes. Esses procedimentos redutores possuem uma força política. Mais do que isso: eles reduzem ideologicamente o conhecimento ao saber dominado e utilizado pelo Estado, pela 
Trata-se aqui, então, do esforço de produzir uma economia política do espaço, que tenha como central o propósito de colocar a nu a questão da reprodução das relações de produção e as contradições que daí advêm, como modo operante de uma geografia urbana crítica ${ }^{28}$. Esse esforço de encontrar os fundamentos subjacentes às manifestações imediatas é um processo coletivo e, por natureza, lento, que avança aos poucos ${ }^{29}$. Ainda que modestamente, este trabalho pretende oferecer uma pequena contribuição nessa direção.

tecnocracia e burocracia estatistas. Juntamente com a dialética, é esvaziado o conhecimento crítico". Tradução nossa.

28 "La crise [de l'économie politique], sous cet angle, signifie que la reproduction des rapports de production vient au jour, se découvre comme telle" (LEFEBVRE, 2000b, p. 106). "A crise [da economia política], sob esse ângulo, significa que a reprodução das relações de produção vem à luz, se descobre como tal". Tradução nossa.

29 'Se a 'essência' fosse posta como um bloco diante de nós, como algo que tivesse de ser conhecido em bloco, como um tudo ou nada, o conhecimento seria impossível; ou então seria uma revelação misteriosa" (LEFEBVRE, 1975, p. 216). 


\section{Das contradições no espaço às contradições do espaço: o lugar do imobiliário na geografia econômica da cidade capitalista}

Uma apreciação preliminar do significado do setor imobiliário na constituição da metrópole contemporânea requer algumas considerações a respeito da especificidade da mercadoria produzida pelo setor. Essas considerações são importantes, porquanto algumas das particularidades que diferenciam o espaço de outras mercadorias estabelecem condições bem diferenciadas para a realização do valor no setor estudado. No que se segue, derivamos algumas conseqüências, para a atividade imobiliária, das particularidades que possuem o solo e suas benfeitorias enquanto mercadorias, conforme elencadas por Harvey $(1980)^{30}$.

Um primeiro aspecto que diferencia o solo e seus melhoramentos de outras mercadorias é o fato de que essa mercadoria não se desloca no espaço. Isso confere ao proprietário o monopólio relativo sobre uma parcela singular do espaço urbano, de modo que só um número reduzido de propriedades pode estar localizado, por exemplo, nas proximidades de uma avenida importante ${ }^{31}$. Esse primeiro aspecto coloca com muita força a presença do Estado, como provedor de infra-estrutura física e social para a reprodução social como um todo. Num contexto de impossibilidade de distribuição plena e equânime das infra-estruturas por todo o tecido urbano, as decisões de alocação de recursos (físicos e sociais) pelo Estado afetam diretamente a atividade imobiliária, principalmente suscitando comportamentos especulativos por parte de proprietários fundiários e investidores ${ }^{32}$. Muitas vezes a especulação serve de combustível para períodos de intensificação dos investimentos em determinados pontos do espaço urbano, sem que isso reflita um crescimento de renda da população residente ou aumento do crédito. É o que acontece, por

${ }^{30}$ A discussão de algumas dessas questões relativas à especificidade do setor imobiliário podem ser encontradas, também, em Lojkine (1997), Abramo (2007) e Botelho (2007), entre outros.

${ }^{31} \mathrm{Se}$, por um lado, Villaça tem razão em afirmar que "na prática, há muitas localizações tão parecidas que, para fins práticos, podem ser consideradas iguais" (2001, p. 75), acreditamos que ainda seja possível de falar do solo urbano como uma forma de monopólio, visto que, por exemplo, somente um número reduzido de propriedades pode estar próximo de determinada centralidade (um shopping center, uma avenida de grande movimento, etc).

${ }^{32}$ Como bem lembrou Villaça (2001), isso não significa dizer que em um contexto de distribuição plena de infra-estrutura física e social, não se formariam centralidades e, portanto, uma superfície desigual de valores do solo. 
exemplo, quando uma obra importante (uma avenida ou uma linha de metrô) altera a posição relativa (situação) de determinada área em relação ao conjunto da metrópole, potencializando a renda da terra passível de ser extraída - o tratamento que Harvey (1980, cap. 5) concede à renda da terra como mecanismo de alocação do uso do solo urbano é elucidativo a este respeito ${ }^{33}$. Obviamente, o uso de campanhas publicitárias que enalteçam os supostos benefícios de se habitar determinada região da cidade contribui para um crescimento do investimento em pontos específicos do tecido urbano, o que torna muito mais complexa a questão da determinação dos níveis de renda da terra quando se trata de uso residencial ${ }^{34}$. Nesse sentido, o tratamento oferecido por Harvey (1999, p. 340) ao problema, em The limits to capital, que explica os diferenciais de renda fundiária urbana para uso residencial em razão de variações em termos de custo de transporte (o trabalhador que vive onde os custos de transportes são menores paga, na forma de renda da terra, esse "ganho" excedente no deslocamento para o trabalho), parece bastante insatisfatório. O que deve ser retido, contudo, é que esse aspecto ressaltado a condição fixa da propriedade do solo - torna mais complexas as relações entre o Estado e os negócios na cidade, problema que deverá será abordado com maior profundidade aqui no caso específico de Porto Alegre.

Mas além dos investimentos propriamente ditos, o Estado interfere no mercado de moradias através de leis de zoneamento e uso do solo, de modo que a formação de poderosos lobbies, encabeçados geralmente pela indústria imobiliária num sentido mais amplo, e com o objetivo de influenciar na elaboração e alteração dessas leis, é um aspecto comum na cidade capitalista $^{35}$. A diferenciação do zoneamento e dos índices de aproveitamento

\footnotetext{
${ }^{33}$ Ainda no âmbito dessa discussão, as considerações de Harvey (1999, p. 388-9) sobre espaço absoluto e espaço relativo no que diz respeito ao mercado de terras são bastante importantes. No que diz respeito à especulação no mercado imobiliário, é interessante observar como certas áreas da cidade parecem entrar em ciclos espaciais de investimento imobiliário, assunto que deverá ser observado com maior rigor quando expusermos algumas transformações a que esteve sujeita a cidade de Porto Alegre em anos recentes.

${ }^{34}$ Essa questão remeteria aos signos que as formas urbanas carregam e que se tornam alvo de comercialização, como os signos da natureza apontados por Lefebvre (2003, p. 27), hoje tão presentes em publicidades de imóveis que supostamente aproximariam o comprador da "natureza". Esse assunto será tratado de forma mais completa no capítulo 4.

${ }^{35} \mathrm{O}$ trabalho antes citado de João Rovatti (1990) explicita bem as disputas em torno da modificação dos índices de aproveitamento do solo em Porto Alegre na década de 1980 e os grupos que se formaram no sentido de influenciar as decisões. Cf. também Harvey (1980, p. 159).
} 
entre os bairros pode acarretar uma valorização em determinadas áreas da cidade em detrimento de outras. É importante assinalar, portanto, que a fixidez da propriedade do solo no contexto do espaço urbano coloca cada propriedade em uma relação complexa com o conjunto da cidade, de forma que, mesmo que a posição absoluta de determinada parcela do espaço nunca se modifique, sua posição relativa (sua situação) está sempre sujeita a profundas alterações que resultam em valorizações e desvalorizações ao longo dos tempos. É isso que ressalta Rachel Weber, para quem "spatialized capital, unlike derivatives or corporate equities, has the unique (dis)advantage of having its value held hostage by the vagaries of proximity and its relationship to other proprieties" $\left(\right.$ WEBER, 2002, p. 521) ${ }^{36}$. Essas incertezas, somada à baixa liquidez do imóvel, são obstáculos que colocam riscos ao investimento imobiliário, mas que são parcialmente superados através de mecanismos diversos - os fundos de investimento imobiliário, por exemplo, dão maior liquidez ao investidor que deseja investir no ambiente construído ${ }^{37}$.

Um segundo aspecto que distingue o espaço (o ambiente construído) de outras mercadorias, por sua própria natureza enquanto valor de uso, é o fato de que sua aquisição requer um dispêndio elevado de dinheiro em um momento, ao passo que seu uso se estende por muitos anos. Também sua produção exige um tempo prolongado, durante o qual são necessários, ao investidor no setor da construção, numerosos adiantamentos em capital circulante (matéria-prima e força de trabalho). Isso confere ao crédito - tanto aquele destinado ao investidor quanto ao consumidor final - um papel de

\footnotetext{
36 “(...) [o] capital espacializado, diferentemente de derivativos ou ações corporativas, tem a particular (des)vantagem de ter seu valor refém das vicissitudes da proximidade e de sua relação com outras propriedades". Tradução nossa. Este trecho, presente em Fainstein (1994, p. 221), evidencia também esse aspecto incerto do preço das propriedades: "O preço de uma propriedade comercial em dez anos depende da quantidade de espaço que outros constróem, da atratividade da área na qual se localiza (o que, em si, é algo bastante subjetivo e pode ser perturbado por eventos inesperados), das necessidades técnicas cambiantes dos ocupantes (ex: demanda por "edifícios inteligentes", espaços amplos de negociação ou escritórios privados com janelas), das decisões governamentais quanto a infra-estrutura, tributação, taxa de juros e da regulação, expansão ou contração da indústria para a qual o edifício foi projetado". Original: "The price of a commercial property in ten years depends on the amount of space that other build, the desirability of the area in which it is located (which is itself very subjective and can be perturbed by unanticipated events), the changeable technical needs of the occupant (e.g. for "smart buildings", large trading floors, or private offices with windows), governmental decisions concerning infrastructure, taxation, interest rates, and regulation, and expansion and contraction of the industry for which the building is designed". Tradução nossa. Cf. também Seabra (1988).

${ }^{37}$ Cf. Weber (2002).
} 
extrema importância na realização do valor produzido pelo setor imobiliário, de modo que parece inimaginável a possibilidade de acumulação de capital no setor sem o desenvolvimento de um sistema financeiro aperfeiçoado, capaz de compatibilizar temporalidades dissonantes e fomentar o desenvolvimento desse mercado específico. É necessário aprofundar um pouco a discussão a esse respeito.

Iniciemos com o momento da produção. Mesmo que os anos recentes tenham testemunhado uma aceleração no tempo de produção dos imóveis, ainda persiste o fato de que seu tempo de produção é elevado e o processo produtivo (ainda) intensivo em mão-de-obra, além de exigir investimentos iniciais de capital elevados, se comparado com outros setores. Durante esse tempo de produção e, portanto, antes que retorne qualquer valor adiantado, são necessários adiantamentos para compra do terreno a incorporar, de material para construção e para o pagamento da força de trabalho (supondo, aqui, uma empresa que seja simultaneamente incorporadora e construtora). Sem um sistema de crédito desenvolvido, que permita que o investidor obtenha sob a forma de empréstimo o capital necessário para dar continuidade à produção, seria necessário uma quantia elevada, em mãos do produtor, na forma de capital de giro. Essas circunstâncias colocam em relação estreita 0 setor da construção e o setor financeiro, de maneira que alterações, por exemplo, na taxa de juros impõem condições diferenciadas para o setor que podem acelerar ou frear a acumulação. Aqui emerge a condição que Marx (1980, v. 3, cap. 21) identifica em que a taxa de juros, o "preço" do capital, aparece como determinante da produção, mesmo que no limite os juros sejam apenas uma parcela da mais-valia produzida pelo setor industrial. Conforme Harvey (1999, p. 187) expôs, a taxa de juros acaba sendo um elemento fundamental no estabelecimento do que o autor denominou "tempo de rotação socialmente necessário do capital". O que ocorre é que capitais que requerem um tempo de rotação mais elevado são penalizados com uma taxa de juros mais elevada para a obtenção de crédito e, por conseguinte, ficam em desvantagem competitiva em relação a outros. No setor da construção imobiliária, o tempo de rotação é essencial, o que explica uma pressão 
crescente por processos produtivos que diminuam o tempo de construção dos prédios $^{38}$.

Mas as formas de financiamento para a produção se multiplicaram em quantidade e qualidade, colocando novas possibilidades para as empresas (principalmente as de maior capital). O exemplo dos Fundos de Investimento Imobiliário (FIl's), dos Certificados de Recebíveis Imobiliários (CRI's) e, sobretudo, das IPOs (Initial Public Offerings, ou Ofertas Públicas Iniciais), lançamento de ações das empresas imobiliárias, apontam para um momento em que surgem novos mecanismos de capitalização por parte das grandes corporações, alterando as relações entre o mercado de terras e o mercado financeiro. Voltaremos a esse ponto.

A realização do valor incorporado ao ambiente construído depende, também, de uma demanda solvável que, sem o auxílio de um sistema financeiro, seria reduzida. O crédito imobiliário é, portanto, fundamental para criar essa demanda e é comum o Estado intervir, criando linhas de crédito específicas para a aquisição de imóveis. No Brasil, foi fundamental, nessa direção, o surgimento do Sistema Financeiro da Habitação (SFH), na esteira da criação do Banco Nacional da Habitação (BNH), a partir da instituição do regime ditatorial militar em 1964. Essa política de financiamento habitacional permitiu, por um certo período, criar uma demanda solvável nos estratos de renda mais baixos que, caso contrário, não teriam acesso ao mercado imobiliário. Todavia, a necessidade de compatibilizar o fornecimento de crédito habitacional a setores populares com um orçamento equilibrado (ou seja, com a circulação rentável do capital a juros), como era o objetivo do governo, foi se tornando difícil à medida que crescia a inadimplência de boa parte dos mutuários. Visto que a inadimplência tendia a se concentrar nos setores mais desfavorecidos economicamente, os financiamentos foram sendo direcionados para as classes média e alta, reduzindo as possibilidades de aquisição de um imóvel por parte da população de renda mais baixa ${ }^{39}$.

A evolução conjunta, portanto, das taxas de juros, para cujo estabelecimento concorre a política monetária do Estado, e das políticas

\footnotetext{
${ }^{38}$ Sobre os efeitos da rotação do capital sobre a taxa de lucro, cf. o capítulo 4 escrito por Engels em Marx (1981), vol. 3.

${ }^{39}$ Cf. Azevedo (1996) e Botelho (2007).
} 
específicas de crédito à produção e ao consumo do ambiente construído influem significativamente nos rumos tomados pela acumulação no setor. Existem claras evidências de que nos anos recentes, marcados por políticas monetárias restritivas características do neoliberalismo, o setor da construção de imóveis foi severamente afetado, assim como o conjunto da produção industrial. Soma-se a isso a extinção, nos anos 1980, do BNH e o encolhimento dos financiamentos imobiliários através do Sistema Financeiro da Habitação, profundamente deficitário. Uma das conseqüências parece ter sido um redirecionamento dos investimentos para atender a classe dominante, por sua capacidade de pagamento elevada, sobretudo num país com elevada concentração de renda, como é o caso do Brasil. Esse redirecionamento teve como resultado uma concentração dos investimentos em certas áreas das metrópoles - sobretudo os bairros mais tradicionais - em detrimento de outras. Retornaremos a esse assunto mais detalhadamente no próximo capítulo.

Mas ainda resta determinar a importância do investimento imobiliário para a reprodução da sociedade capitalista. É conhecida a tese de David Harvey (1999), já mencionada acima e que deve tributo a Henri Lefebvre (2000a; 2000b; 2003), de que ciclos de investimento em capital fixo, do qual faz parte o ambiente construído, derivariam de uma tendência à sobreacumulação no circuito primário (produção de bens de consumo). O circuito secundário (capital fixo) seria responsável por mitigar essa tendência à sobreacumulação inerente à reprodução capitalista, funcionando como uma válvula de escape que permitiria uma recuperação da lucratividade (ou, ao menos, uma barreira a uma queda mais acentuada da lucratividade), idéia evidenciada no trecho abaixo de Lefebvre:

[...] I would like to highlight the role played by urbanism and more generally real estate (speculation, construction) in neocapitalist society. Real estate functions as a second sector, a circuit that runs parallel to that of industrial production, which serves the nondurable assets market, or at least those that are less durable than buildings. This second sector serves as a buffer. It is where capital flows in the event of a depression, although enormous profits soon slow to a trickle. In this sector, there are few multipliers, few spin-offs. Capital is tied up in real estate. Although the overall economy (so-called domestic economy) soon begins to suffer, the role and function of this sector continues to grow. As the principal circuit - current industrial production and the movable property that results - begins to slow down, capital shifts to the second sector, real estate. It can even happen that real estate speculation becomes the principal source for 
the formation of capital, that is, the realization of surplus value. As the percentage of overall surplus value formed and realized by industry begins to decline, the percentage created and realized by real estate speculation and construction increases. The second circuit supplants the first, becomes essential ${ }^{40}$ (LEFEBVRE, 2003, p. 59-60).

Fainstein (1995, p. 222-3), por exemplo, critica a teorização de David Harvey por não encontrar evidências de que o ciclo de investimento imobiliário poderia contrabalançar os declínios periódicos da produção industrial ${ }^{41}$. E, de fato, à primeira vista, o investimento na construção parece seguir, em linhas gerais, a trajetória da economia como um todo. Basta que comparemos as taxas de crescimento para a totalidade da economia com as taxas prevalentes no setor da construção. Mas uma crítica a teoria nesses termos revela-se insuficiente. Harvey (e Lefebvre) nunca propugnou a idéia de que os investimentos no circuito secundário conseguiriam blindar o capitalismo das crises mais amplas. O que o autor propõe é que em certas circunstâncias históricas, em que ocorrem crises localizadas, o investimento no ambiente construído proporcionaria uma saída temporária e, em seu artigo The urban

\footnotetext{
40 "Gostaria de sublinhar o papel do urbanismo, e de maneira mais ampla, do imobiliário (especulação, construção) na sociedade neocapitalista. O imobiliário funciona como um segundo setor, um circuito paralelo àquele da produção industrial, que responde por bens não-duráveis ou menos duráveis que os imóveis. Esse segundo setor absorve os impactos. É para onde flui o capital no caso de uma depressão, embora lucros iniciais enormes logo se transformem em ganhos ínfimos. Nesse setor, existem poucos multiplicadores. O capital se imobiliza no imobiliário. Embora a economia como um todo (a chamada economia nacional) logo comece a sofrer, o papel e a função desse setor continuam a crescer. À medida que o circuito principal - a produção industrial de bens móveis - começa a se desacelerar, o capital se desloca para o circuito secundário, o imobiliário. Pode até mesmo ocorrer que a especulação imobiliária se torne a principal fonte para a formação de capital, ou seja, para a realização da mais-valia. À medida que diminui a porcentagem total de mais-valia criada e realizada pela indústria, cresce a porcentagem criada e realizada pela especulação e construção imobiliária. O circuito secundário, então, suplanta o primário e se torna essencial". Tradução nossa.

${ }^{41}$ Ao fazer isso, a autora, além de descartar uma teoria do valor como resultado do trabalho socialmente necessário, descarta também uma teoria da renda, atribuindo valor (e não preço) à terra como resultado de sua capacidade de captar externalidades (valor incorporado nos arredores). $\mathrm{O}$ fato de que o preço da terra incorpora sua posição relativa à totalidade do ambiente construído que constitui a cidade não parece, em nosso entendimento, estar em contradição com a teoria da renda da terra, que postula que o preço da terra é constituído a partir da capitalização da renda que ela é capaz de gerar. A renda não é nada mais do que a captura dos benefícios de aglomeração proporcionados pela urbanização, que varia conforme as possibilidades de acessibilidade a esses benefícios. Nesse sentido, as divergências entre, por exemplo, autores que postulam a existência de renda do solo urbano, como David Harvey (1980; 1999) e Neil Smith (1996), e aqueles que crêem que o solo urbano possui valor, derivado do trabalho social incorporado na cidade, como Carlos (1994) e Villaça (2001), não parecem ser tão grandes. Convém ainda dizer que concordamos com Gottdiener (1994) ao rechaçar uma transposição mecânica da teoria da renda do solo agrícola para a cidade.
} 
process under capitalism: a framework for analysis (1989), apóia tais argumentos em evidências históricas que parecem inequívocas ${ }^{42}$.

Não é objetivo nem pretensão desta pesquisa, entretanto, adentrar a complexa discussão teórica, que de todo modo se situa para além de nossas possibilidades, acerca do potencial contra-cíclico que o investimento no ambiente construído possuiria em relação ao conjunto da economia. Ainda que não consiga reverter um quadro de baixo crescimento econômico, isso não invalida a hipótese de que o investimento imobiliário tem sido uma das saídas lucrativas encontradas pelo capital que tem tido dificuldade de se valorizar em outros setores. Jason Hackworth (2007), por exemplo, sugere a ocorrência, a partir dos anos 1970, de um ajuste espacial neoliberal, que teria a promoção do investimento imobiliário (agora mais direcionado para as áreas urbanas centrais das cidades americanas) como um dos seus suportes fundamentais ${ }^{43}$. O surgimento de formas de gestão urbana mais comprometidas com 0 propósito de criar condições para a valorização do capital investido no ambiente construído é, nesse sentido, um testemunho, além do poder dos incorporadores em definir os rumos da política local, de que a produção do espaço assume um lugar proeminente no período atual ${ }^{44}$, conforme já havíamos salientado anteriormente. Não se trata, contudo, de afirmar que a produção do espaço ofuscou a indústria e outros setores da economia, que se tornou mais importante, mas sim de reconhecer que o espaço se inseriu com mais vigor nos circuitos de valorização do capital nesses últimos 50 anos do que havia sido o caso até então. É uma nova fronteira que o capitalismo engendrou/aperfeiçoou como possibilidade de investimento lucrativo. Uma citação de Lefebvre é necessária porque explicita bem o significado do imobiliário como nova fronteira:

\footnotetext{
${ }^{42}$ Basta que pensemos, também, nos diversos booms imobiliários recentes que apresentam certa autonomia do conjunto da economia. As considerações de Ball (1983), por exemplo, parecem sustentar a tese principal de David Harvey. O autor explica por que o investimento imobiliário é atrativo e mostra como muitas empresas de outros ramos abriram subsidiárias no setor imobiliário como forma de escoar seu capital excedente.

${ }^{43}$ Os traços característicos desse ajuste espacial parecem ser distintos no Brasil, se comparamos com o cenário identificado por Hackworth (2007) para os Estados Unidos. Ainda assim, algumas semelhanças se impõem: a proliferação de condomínios fechados de classe média e alta distantes do centro, o esforço pela revalorização das áreas centrais e os investimentos em megaprojetos imobiliários.

${ }^{44}$ Cf. Smith (1996; 2002; 2006); Merrifield (2002); Hackworth (2007).
} 
L'immobilier, dans le capitalisme, n'eut longtemps qu'une importance mineure. Le sol appartenait aux débris d'une classe vaincue, les proprietaires fonciers, classe en tant que telle d'origine féodale. Branche de production d'abord subordonnée, presque artisanale, la construction avait jadis moins d'importance que la production de l'acier ou du sucre (malgré l'adage: quand le bâtiment va, tout va). Or, la situation de cette "branche" a complètement changé, et pas seulement dans les grands pays industriels. II ne suffit pas de rappeler, pour expliquer ce fait, les phénomènes généraux d'urbanisation, l'extension des villes, les progrès technique, etc. II faut montrer comment et pourquoi le capitalisme a pris possession du sol, de l'espace (LEFEBVRE, 2000b, p. 111)

A mobilização do espaço, até então secundário no processo total de produção e circulação do capital, e sua inserção nos circuitos da reprodução ampliada (do capital), teve como resultado fundamental o de que a renda da terra, outrora um tributo devido a uma classe de proprietários oriundos de uma formação econômica e social precedente, se configurasse em mais uma forma entre aquelas que a circulação do capital a juros admite. A própria figura do proprietário de terras, enquanto classe nitidamente independente da burguesia, e que extrai uma fatia da mais-valia produzida em determinado setor, torna-se opaca, na medida em que se generaliza a redução da terra a uma forma de ativo financeiro (capital fictício) ${ }^{46}$. $O$ investimento na propriedade da terra, portanto, adquire a condição de uma opção a mais entre as possibilidades abertas ao investimento em capital fictício. É interessante observar que Marx já havia percebido essa realidade (e ao mesmo tendência) na década de 1840, como o atesta o longo, mas necessário, trecho abaixo extraído dos Manuscritos econômico-filosóficos:

É necessário que esta aparência [a relação aristocrática com a terra] seja supra-sumida (aufgehoben), que a propriedade fundiária, a raiz da propriedade privada, seja completamente arrastada para dentro do movimento da propriedade privada e se torne mercadoria; que a dominação do proprietário apareça como a pura dominação da propriedade privada, do capital, dissociado de toda a coloração

\footnotetext{
45 "Durante muito tempo, o "imobiliário" não teve, no capitalismo, mais do que uma importância menor. O solo pertencia aos últimos representantes de uma classe vencida, os proprietários fundiários, classe que, como tal, é de origem feudal. Ramo de produção inicialmente subordinado, quase artesanal, a construção tinha, anteriormente, menos importância do que a produção de aço ou açúcar (em que pese o adágio: quando a construção vai bem, tudo vai bem). Ora, a situação desse "ramo" mudou completamente, e não apenas nos grandes países industriais. Não basta recordar, para explicar esse fato, os fenômenos gerais de urbanização, a extensão crescente das cidades, os avanços técnicos, etc. É preciso mostrar como e por quê o capitalismo tomou possessão do solo, do espaço". Tradução nossa. Cf. também Lefebvre (2003, p. 155).

${ }^{46}$ Cf. Harvey (1999, cap. 11).
} 
política; que a relação entre proprietário e trabalhador se reduza à relação nacional-econômica de explorador e explorado; que toda a relação pessoal do proprietário com sua propriedade termine, e esta se torne, ela mesma, apenas riqueza material coisal; que no lugar do casamento de honra com a terra se instale o casamento por interesse, e a terra, tal como o homem, baixe do mesmo modo a valor de regateio. É necessário que aquilo que é a raiz da propriedade fundaria, o sórdido interesse pessoal, apareça também na sua cínica figura. É necessário que o monopólio inerte se transmute em monopólio em movimento e inquieto - a concorrência; [que] a fruição ociosa do suor e do sangue alheios se transmute num comércio multiativo com os mesmos. Finalmente, é necessário que nesta concorrência a propriedade fundiária mostre, sob a figura do capital, a sua dominação tanto sobre a classe trabalhadora, quanto sobre os próprios proprietários, na medida em que as leis de movimento do capital os arruínem ou promovam. Assim, entra no lugar do provérbio medieval: nenhuma terra sem senhor (nulle terre sans seigneur), o provérbio moderno: o dinheiro não tem dono (l'argent n'a pas de maître), no qual é exprimida a completa dominação da matéria morta sobre o homem ${ }^{47}$ (MARX, 2004, p. 75).

Fundamental, contudo, para que o espaço se inserisse com mais vigor nos circuitos da valorização do capital foi um crescimento das forças produtivas que viabilizou a produção do espaço numa escala antes não alcançada. É aqui que se revela o sentido dos argumentos de Lefebvre (2000a, p. 375) sobre os riscos de reduzir o capitalismo a um esquema binário que oporia capital e trabalho, e para dar lugar ao terceiro elemento da fórmula trinitária sobre a qual Marx se debruçou em determinado momento da produção de sua obra principal. E, então, se por um lado a classe dos proprietários de terra se enfraquece frente ao movimento que transforma a terra em capital fictício, em riqueza mobiliária, como foi dito anteriormente, por outro, Lefebvre destaca que a terra e o solo em sentido amplo colocam problemas específicos cuja natureza deve receber nossa atenção. O espaço surge, então, para Henri Lefebvre (2000a, p. 108), como uma nova problemática para cuja elucidação é indispensável um esforço de teorização ${ }^{48}$. Essa teorização é necessária, em primeiro lugar, porque o espaço contém relações sociais, mas dissimulando-as (LEFEBVRE, 2000a, p. 100). Seria tarefa de uma economia política do espaço, então, penetrar nos fundamentos que estão por trás da visibilidade do

\footnotetext{
${ }^{47}$ Gottdiener (1997, cap. 5) oferece importantes considerações sobre a propriedade da terra em sua relação com o urbano. Cf. também Lefebvre (1999, cap. 2).

${ }^{48}$ Com a noção de "campo cego", Lefebvre (2003, cap. 2) repudia o fato de que o período que se anuncia (urbano) continue sendo analisado e interpretado com conceitos e categorias herdadas do período anterior, e, portanto, insuficientes para compreender o novo que se anuncia.
} 
espaço $^{49}$, identificar as contradições que não estão apenas no espaço, mas são contradições do espaço ${ }^{50}$. Para Amélia Damiani (2001, p. 50), "se não examinássemos a produção do espaço sob o enfoque de suas contradições, não recuperaríamos o sentido deste momento na história humana e, por outro, sua singularidade. Do ponto de vista das contradições, a crise e o movimento ganham existência (...)". De acordo com Lefebvre (2000a, p. 106), o princípio da interpenetração dos espaços sociais coloca a possibilidade de um desvendamento desses fundamentos a partir da análise de um fragmento do espaço. É esse princípio que nos permite, portanto, buscar algumas das determinações mais universais da reprodução capitalista no desdobramento da atividade imobiliária na cidade de Porto Alegre ${ }^{51}$.

49 “(...) le caractere social de l'espace (les rapports sociaux qu'il implique, qu'il contient et dissimule) commencent à l'emporter visiblement. Ce trait caractéristique, la visibilité, n'entraîne pourtant la lisibilité des rapports inhérents. L'analyse de ces rapports, au contraire, devient dificile, à ce point qu'il lui arrive d'avoisiner le paradoxe” (Lefebvre, 2000, p. 100). “(...) o caráter social do espaço (as relações sociais que ele implica, contém e dissimula) começam a aparecer visivelmente. Esse traço característico, a visibilidade, não conduz, entretanto, à legibilidade das relações inerentes. A análise dessas relações, ao contrário, torna-se difícil, a tal ponto que se aproxima do paradoxo. Tradução nossa.

50 "Les contradictions de l'espace, sans abolir celles qui proviennent du temps historique, sortent de l'histoire et dans la simultanéité mondiale portent à un autre niveau les contradictions anciennes, les unes s'émoussant, d'autres s'aggravant (...)" (LEFEBVRE, 2000, p. 153). "As contradições do espaço, sem eliminar aquelas que provêm do tempo histórico, saem da história e, na simultaneidade mundial, elevam a um outro nível as contradições antigas, algumas sendo abrandadas, outras agravadas". Tradução nossa. Cf. também Lefebvre, 1978, p. 75-6, vol. 4.

${ }^{51} \mathrm{E}$ aqui podemos entender o objeto da pesquisa como um "momento" do real, sem que seja possível, sob risco de redução grosseira, descolá-lo da totalidade do movimento da sociedade. Sobre esse aspecto, diz Lefebvre (1975, p. 119): "Analisar uma realidade complexa e atingir seus elementos reais é o mesmo que descobrir seus momentos. A análise deve ser operada no movimento, no processo criador. (...) A análise deve sempre captar corretamente essa relação complexa, contraditória, dos momentos entre si e com a totalidade". Um ponto de vista semelhante foi expresso por Lukács (2003, p. 342-3) quando diz que "a essência do método dialético (...) consiste no fato de que a totalidade está compreendida em cada aspecto assimilado corretamente pela dialética e de que todo 0 método pode desenvolver-se a partir de cada aspecto". Ainda para Lukács (ibidem, p. 344), "[o] aspecto isolado deveria ser visto como aquele que contém a possibilidade de desenvolver, a partir dele, todo o conteúdo da totalidade". 


\section{A espacialidade da valorização capitalista: um panorama dos} movimentos espaciais do capital imobiliário na evolução recente da metrópole gaúcha

Se a análise de um fragmento do espaço permite-nos discernir alguns dos nexos determinativos da reprodução dessa sociedade, ela requer, por outro lado, um cuidado redobrado, senão vejamos.

Um risco muito grande que se apresenta a qualquer análise que lide com a interpenetração de escalas é o da sobrevalorização de uma das escalas constituintes do problema abordado. Por um lado, há o perigo de atribuir-se valor exagerado aos movimentos estruturais, às determinações mais gerais, na explicação do desdobramento do processo na escala local. Tal procedimento, se conduzido ao extremo, retira o sentido de uma análise da escala local, na medida em que o local se torna um reflexo imediato das determinações advindas das escalas mais amplas - procedimento que, na maior parte das vezes, adota uma abordagem estrutural que nega os indivíduos e grupos sociais enquanto sujeitos ativos na constituição da sociedade. $O$ equívoco oposto também é deletério: examinam-se os processos que se desdobram na escala local negligenciando as determinações que procedem de escalas mais amplas, e que impõem, necessariamente, limites e direções para os movimentos ocorridos na escala local. Esse último procedimento resvala, freqüentemente, para uma pura descrição do local, sem conseguir atingir os fundamentos subjacentes à aparência dos fenômenos ${ }^{52}$.

A questão das escalas, muito cara à Geografia, é sobremaneira complexa e requer uma reflexão cuidadosa. Partimos de um entendimento de que na escala local se entrelaçam processos advindos de outras escalas que, ainda que nunca eliminem o local, impõem restrições e direções que retiram

\footnotetext{
${ }^{52} \mathrm{O}$ problema das escalas muitas vezes encontra-se entrelaçado com o debate sobre a relação entre sujeito e estrutura no que concerne à mudança social, questões que marcaram o pensamento marxista e sociológico em geral durante o século $X X$ e deram origem a diferentes perspectivas. O problema aparece em Lefebvre (2003, cap. 4) quando o autor trata da questão dos níveis da realidade, apontando para o fato de que o predomínio do nível Global (G) caracteriza o mundo atual, invertido, sugerindo, então, que a superação desse mundo invertido consistiria no predomínio do nível $\mathrm{P}$ (o nível do habitar, do vivido). A forma como a organização/estruturação do espaço urbano se encontra, hoje, atada aos movimentos do capital global (por exemplo, através da conexão entre os níveis de preços da terra e as taxas de juros) evidenciam esse predomínio do nível G. Para um exame da questão de escala conforme aparece na obra de Henri Lefebvre, cf. Brenner (2000).
} 
parte da autonomia do local no que diz respeito ao direcionamento da mudança social. O que é importante, contudo, é que a potência adquirida pelas escalas maiores no sentido de direcionar as transformações ocorridas nas escalas menores (local e regional) varia histórica e geograficamente. É a própria análise, portanto, que permitirá verificar qual é o peso de cada escala no direcionamento da mudança social ocorrida no espaço local, ainda que possamos nos posicionar ao lado de Lefebvre (2003) quando o autor sugere que a sociedade atual (alienada, reificada) caracteriza-se pelo predomínio do nível $\mathrm{G}$, das relações abstratas de mercado e de dominação estatista em detrimento do vivido, da ordem distante em detrimento da ordem próxima. A importância da questão da escala, e os riscos a ela associados, deverão estar presentes na exposição que se segue ${ }^{53}$.

O desenvolvimento da acumulação capitalista na produção do ambiente construído urbano deve incluir, conforme já assinalado no início do texto, uma idéia de desenvolvimento desigual que se manifesta na escala local ${ }^{54}$. A construção de uma teoria do uso do solo urbano em que esteja presente uma noção do dinamismo com que o capital constrói e destrói paisagens urbanas e as valorizações e desvalorizações a que estão sujeitos os fragmentos da metrópole é um desafio importante para o pensamento sobre a cidade enfrentado, em anos recentes, por alguns autores ${ }^{55}$. Ainda assim, muitos problemas persistem. A elaboração de tal teoria permitiria não apenas superar

\footnotetext{
${ }^{53}$ Essa questão tem aparecido com muita força na Geografia Crítica anglo-saxônica, que ressalta o fato de que a relação entre escalas está sujeita a constantes mudanças. Gough (2004), por exemplo, destaca que uma mudança de escala que atinge os processos sociais freqüentemente significa uma mudança nas relações de classe. Brenner (2000, p. 361), em seu artigo cujo propósito central é debater a questão da escala à luz da obra de Henri Lefebvre, diz que "a problemática da escala geográfica e sua produção social tornou-se central para a teoria urbana crítica no atual período de reestruturação global". Tradução nossa. Sobre a relação entre ordem próxima e ordem distante, cf. também Lefebvre (2002, p. 12-3).

${ }^{54} \mathrm{O}$ trecho a seguir, retirado de Neil Smith (1996, p. 86-7), descreve alguns dos resultados, na escala urbana, produzidos pelo desenvolvimento desigual, especialmente nos anos recentes: "Uneven development at the urban scale (...) brought not only gentrification in the narrowest sense but the whole new gamut of restructurings: condominium conversions, office construction, recreational and service expansion, massive redevelopment, projects to build hotels, plazas, restaurants, tourist arcades and so on". Tradução nossa: "O desenvolvimento desigual na escala local trouxe consigo não apenas a gentrificação em sentido estrito, mas toda uma nova gama de reestruturações: conversões de estruturas antigas em condomínios, construção de torres de escritórios, expansão do setor de serviços e entretenimento, redesenvolvimento em escala ampliada, projetos para a construção de hotéis, centros comerciais, restaurantes, galerias para turistas, etc".

${ }^{55}$ Cf. Harvey (1978; 1989; 1999); Smith (1996);
} 
a ficção sobre a qual se assenta a teoria neoclássica do uso do solo - qual seja, a de um mercado de terras em equilíbrio que alocaria racionalmente os usos do solo - mas também apontar o momento crítico do processo de produção e reprodução das metrópoles, que residiria, em grande medida, na reiteração das periferias como impossibilidade da centralidade para todos numa cidade refém da lógica mercantil.

A constituição da metrópole a partir dos movimentos dinâmicos colocados pela acumulação é um processo complexo e intricado, não facilmente discernível à primeira vista. A produção capitalista do ambiente construído desdobra-se produzindo uma paisagem desigual que resulta, em grande parte, da operação de fronteiras de acumulação. Essas fronteiras podem ser entendidas como áreas da cidade que, se antes não se encontravam no centro dos interesses do capital imobiliário, passam a atrair os investidores por representar uma possibilidade de investimento lucrativo possibilidade colocada, em primeiro lugar, pela apropriação privada do potencial de renda da terra disponível em uma área. As considerações de César Santos, que utiliza, à sua maneira, o conceito de território-reserva presente em Rosa Tello, são pertinentes a esse respeito:

O mecanismo de valorização capitalista que passa pelo imobiliário conta com a disponibilização recorrente de espaços para investimentos que, por uma somatória de fatores como custos, rentabilidade e riscos, recai sempre sobre um território restrito dentro da cidade. Como se trata de um processo reiterado de liberação de espaço a cada nova rodada de investimentos, os mesmos territórios entram diversas vezes, com possibilidades, ordenações, funções e significados diferentes, nos mecanismos de valorização do imobiliário. Para que um mesmo espaço, já desgastado ou sobrecarregado no mercado especulativo, retorne sob a forma de ativo imobiliário é preciso que haja antes uma desvalorização dos ativos representados por esse mesmo espaço. Como esse processo se dá no tempo em que os capitais migram de um espaço já saturado para um mais promissor em termos de rentabilidade e segurança, até que ele retorne ao território de origem, um tempo de espera coloca, justamente, esse território abandonado (pelos capitais) desvalorizado, portanto - na condição de um território-reserva; condição essa que somente abandonará quando novos investimentos maciços de capital chegarem aí na expectativa de uma promissora valorização. (...) Investidores, em conjunto, direcionam, num dado momento, uma grande monta de recursos para lugares definidos segundo os patamares de rentabilidade ofertados. No entanto, a mobilidade dos investimentos financeiros, quando aplicada na base dos valores imobiliários, produz toda uma sorte de incertezas e instabilidades decorrentes da volatilidade desses capitais. Assim como há uma chegada maciça de investimentos, num dado momento, 
para um determinado lugar, há uma fuga na mesma velocidade - ou numa velocidade ainda maior - para "novos" espaços mais promissores (SANTOS, C., 2006, p. 120-1).

O trecho abaixo de Neil Smith complementa as idéias já discutidas:

The logic of uneven development is that the development of one area creates barriers to further development, thus leading to an underdevelopment that in turn creates opportunities for a new phase of development. Geographically, this leads to the possibility of what we might call a "locational seesaw": the successive development, underdevelopment and redevelopment of given areas as capital jumps from one place to another, then back again, both creating and destroying its own opportunities for development ${ }^{56}$ (SMITH, 1996, p. 88).

Essas fronteiras urbanas, incessantemente construídas e destruídas, como bem observou Santos no trecho supracitado, podem resultar da operação do que Neil Smith denominou rent gap, que seria um diferencial entre a renda da terra extraída em um momento dado e aquela que seria passível de ser extraída uma vez que se instalasse, na área em vista, o melhor uso do solo. 0 rent gap, então, seria um indicativo das possibilidades de valorização, através da apropriação da renda da terra, à disposição do capital em determinada área da cidade. Ao observamos o desenvolvimento urbano recente em algumas cidades brasileiras, não é difícil visualizar a operação de rent gaps em áreas pericentrais e o ressurgimento de investimentos que conferiram novo sentido a essas áreas ${ }^{57}$.

Essa forma de manifestação da fronteira permite-nos compreender o fato de que o desenvolvimento do capitalismo na cidade recoloca permanentemente seus próprios pressupostos, ou seja, produz e reproduz novas fronteiras, engendrando ciclos de investimento imobiliário concentrados

56 "A lógica do desenvolvimento desigual diz que o desenvolvimento de uma área cria barreiras para o desenvolvimento subseqüente dessa mesma área, conduzindo, portanto, a um subdesenvolvimento que, por sua vez, cria as oportunidades para uma nova fase de desenvolvimento. Geograficamente, isso conduz à possibilidade do que podemos chamar "vaivém locacional": o desenvolvimento, subdesenvolvimento e redesenvolvimento sucessivos de determinadas áreas à medida que o capital salta de um lugar para o outro e de volta, criando e destruindo suas próprias oportunidades de desenvolvimento". Tradução nossa.

${ }^{57}$ É importante observar que a operação do rent gap, fruto de um descompasso entre a renda da terra efetiva e a potencial, está associada, em muitos casos, a áreas centrais, e foi para a compreensão da revalorização destas áreas que Neil Smith dedicou sua teoria. Ainda assim, seria incorreto afirmar que o rent gap opera somente nessas áreas, e isso o próprio autor destaca em vários momentos. 
no tempo e no espaço ${ }^{58}$. Assim, uma mesma área pode, depois de um período longo de desinvestimento, ser reincorporada ao circuito da acumulação de capital, produzindo uma nova centralidade dos investimentos. Mas a fronteira também pode se manifestar, e aqui de forma mais concreta, na incorporação de áreas anteriormente rurais ao tecido urbano. Não se trata de afirmar que nesse caso não exista um rent gap, mas o fato de que existe aqui uma mudança de uso tão marcada que coloca o problema de outra forma. Deve-se atentar, contudo, para o fundamento do processo, qual seja, o de que o capitalismo, também na escala local, reproduz-se desigualmente, recolocando a dialética centro e periferia, perseguindo novas fronteiras que permitam dar continuidade à reprodução ampliada do capital e inserindo, destarte, na espacialidade urbana uma racionalidade técnica e formal abstrata que fragmenta e homogeneíza o espaço da vida. A constituição de fronteiras urbanas, então, revela-se um processo repleto de derivações que atingem diretamente a vida cotidiana, impondo constrangimentos múltiplos às possibilidades de apropriação do espaço e, portanto, desencadeando reivindicações e lutas - sociais, políticas - que podem atingir um grau maior ou menor de consciência. Daí que Smith observe que "do ponto de vista dos moradores da classe trabalhadora e de suas comunidades (...) a fronteira urbana é mais diretamente política do que econômica" (SMITH, 2007, p. 29).

A formação de relevos econômicos identificáveis na paisagem da metrópole gaúcha coloca-nos, portanto, o desafio de encontrar a maneira como opera essa dinâmica intricada na produção do espaço de Porto Alegre. Ainda que seus limites sejam mais acanhados quando comparada com as cidades de São Paulo e Rio de Janeiro, a metrópole gaúcha possui um mercado imobiliário suficientemente desenvolvido para permitir-nos aventar a hipótese de que também nessa cidade se constituem estratégias imobiliárias que prezam pela diversificação (espacial, social, etc) dos investimentos na cidade como saída para minimizar riscos, exatamente como Volochko (2007) identificou para o caso da metrópole paulista. Além disso, como é próprio do mercado residencial

\footnotetext{
${ }^{58}$ Sobre isso, Neil Smith (1996, p. 61) diz: "A theory of gentrification will need to explain the historical process of capital devalorization in the inner city and the precise way in which this devalorization produces the possibility of profitable reinvestment". Tradução: "Uma teoria da gentrificação precisará explicar o processo histórico de desvalorização do capital nas áreas centrais e a maneira precisa pela qual essa desvalorização produz a possibilidade do reinvestimento lucrativo". Tradução nossa. Grifo do autor.
} 
das metrópoles, a busca por inovações traz conseqüências desestabilizadoras para a estruturação urbana que devem ser devidamente analisadas e colocadas em contexto. Esse aspecto da inovação é ressaltado por Abramo (2007), que utiliza-se de um aparato conceitual fundamentalmente keynesiano para uma crítica da teoria do uso do solo urbano preconizada pela economia urbana neoclássica - o que o autor denomina "síntese espacial neoclássica" ${ }^{2}$. O destaque sobre os efeitos desestabilizadores da inovação também pode ser encontrado em Harvey (1999), sobretudo em sua discussão sobre a circulação do capital fixo, embora suas preocupações não estejam direcionadas exclusivamente para o contexto do mercado imobiliário urbano. São essas questões que procuraremos identificar neste e no próximo capítulo, atentando para essas estratégias empresariais como condições sine qua non para que o capital imobiliário evite incorrer em desvalorizações.

A elucidação da dinâmica recente do mercado imobiliário da cidade requer um recuo no tempo para encontrar alguns dos fundamentos, latentes no período considerado, que constituem o momento atual. Embora fundada já no século XVIII, a centralização política e, sobretudo, econômica do Estado na cidade de Porto Alegre ganha impulso somente em fins do século XIX, quando há um redirecionamento dos investimentos, antes destinados à atividade comercial, para a atividade industrial e para a especulação fundiária, com a formação de companhias de loteamento como a Companhia Predial e Agrícola, que teve praticamente o monopólio da comercialização de terrenos na capital entre 1900 e 1920 (STROHAECKER, 2005). Essas companhias de loteamento tinham estratégias elaboradas de valorização de seus terrenos, entre as quais se destacava a compra de ações de companhias de serviços públicos (transporte, saneamento) com o objetivo de pressionar essas empresas a estenderem seus serviços às áreas loteadas (STROHAECKER, 2005). Os principais acionistas da Cia. Predial e Agrícola, por exemplo, dispunham de cargos importantes no setor público e no setor privado, o que facilitava 0

59 Alguns dos conceitos utilizados por Pedro Abramo (2007), embora derivando de uma orientação teórico-metodológica diferente daquela utilizada nesse trabalho, podem contribuir para um melhor entendimento das valorizações/desvalorizações que organizam/estruturam a produção do espaço urbano sob o capitalismo. 
sucesso de suas estratégias de valorização (ver Tabela 1$)^{60}$. A essas ações somavam-se as limitadas exigências feitas pelo poder público para a criação de loteamentos, o que garantia uma considerável rentabilidade aos negócios. $\mathrm{O}$ surgimento das companhias de loteamento significou uma inflexão importante na dinâmica do mercado de terras local, fazendo desaparecer do cenário a figura do proprietário de terras isolado (STROHAECKER, 2005, p. 5). Multiplica-se, com o advento das companhias de loteamento, o poder do capital imobiliário de ditar os rumos da urbanização da capital gaúcha de forma a servir seus interesses.

Tabela 1 - Cargos públicos e privados dos acionistas da Cia. Predial e Agrícola.

\begin{tabular}{|c|c|c|}
\hline $\begin{array}{l}\text { Principais acionistas } \\
\text { da Cia Predial e } \\
\text { Agrícola }\end{array}$ & $\begin{array}{l}\text { Cargos no setor } \\
\text { privado }\end{array}$ & $\begin{array}{l}\text { Cargos no setor } \\
\text { público }\end{array}$ \\
\hline Manoel Py & $\begin{array}{l}\text {-Diretor da Cia. Hidráulica } \\
\text { Porto Alegrense } \\
\text {-Diretor da Cia. Carris } \\
\text { Porto Alegrense (bondes) }\end{array}$ & $\begin{array}{l}\text {-Deputado estadual por } 4 \\
\text { mandatos (1893-1909) } \\
\text {-Deputado Federal }\end{array}$ \\
\hline $\begin{array}{l}\text { Possidônio } \text { Mâncio } \text { da } \\
\text { Cunha Jr. }\end{array}$ & $\begin{array}{l}\text {-Presidente da Cia. Força } \\
\text { e Luz } \\
\text { - Presidente da Cia. } \\
\text { Telefônica Rio-grandense }\end{array}$ & $\begin{array}{l}\text { - Secretário Estadual da } \\
\text { Fazenda e de Obras } \\
\text { Públicas } \\
\text {-Deputado estadual } \\
\text {-Deputado federal }\end{array}$ \\
\hline $\begin{array}{l}\text { José Luiz Moura de } \\
\text { Azevedo }\end{array}$ & $\begin{array}{l}\text {-Diretor-gerente da Cia. } \\
\text { Territorial Porto-alegrense } \\
\text {-Diretor da Cia. Hidráulica } \\
\text { Porto-alegrense } \\
\text {-Diretor-secretário da Cia. } \\
\text { Carris Porto-alegrense }\end{array}$ & \\
\hline
\end{tabular}

Fonte: Strohaecker (2005).

Com o processo de industrialização e a complexificação social dele resultante, o poder público passou a se preocupar mais em investir em infraestrutura para equipar a área central cidade, abrindo avenidas e instalando redes de bondes elétricos e iluminação, sobretudo durante as administrações de Otávio Rocha (1924-1928) e Alberto Bins (1928-1937). Esse processo

${ }^{60} \mathrm{O}$ caso de São Paulo no final do século XIX e início do século XX, descrito em Botelho (2007, cap. 5) assemelha-se bastante ao que Strohaecker (2005) identificou para Porto Alegre, em termos de estratégias utilizadas para a valorização do solo urbano. Ver Gottdiener (1994, cap. 6) para a mescla de interesses públicos e privados que se fusionam para defender os interesses do setor imobiliário. 
acarretou na expulsão das camadas de mais baixa renda da área central da cidade, através da cobrança de imposto sobre os imóveis que agora seriam classificados por localização (urbana, suburbana), densidade (número de pavimentos) e tipologia (cortiços, de madeira, etc) (STROHAECKER, 2005). Essa modernização da infra-estrutura e da taxação foi

[...] acompanhad[a] de uma campanha de "saneamento moral" do centro da cidade, com o combate à prostituição, à mendicância, ao jogo, ao alcoolismo, bem como às habitações populares (cortiços, porões e pensões populares). Com efeito, a abertura da avenida Borges [de Medeiros] e da avenida 24 de maio ([atual] Otávio Rocha) visava reurbanizar áreas do centro onde se concentravam tradicionalmente becos, cortiços e outras formas de habitação (MONTEIRO, 2004, p. 55).

O desenvolvimento da industrialização e das atividades comerciais e, por conseguinte, da divisão do trabalho em Porto Alegre, somados ao desenvolvimento dos transportes intra-urbanos, permite-nos verificar o ainda incipiente processo de implosão-explosão da cidade (LEFEBVRE, 2003) em meados da década de 1920. As camadas populares, deslocadas do centro da cidade pelas políticas de embelezamento e enobrecimento, passam a se localizar nos bairros mais ao norte, próximos à área industrial da cidade na época (Navegantes). Essas áreas ainda dispunham de pouca infra-estrutura e, em muitos locais, estavam sujeitas a enchentes. A elite local (industrial e comercial), por outro lado, desloca-se para leste acompanhando a área mais elevada da topografia da cidade denominada Crista da Matriz, ocupando, inicialmente, as áreas mais altas da rua Duque de Caxias, a Av. Independência e o atual bairro Moinhos de Vento. A área central, por sua vez, passa a abrigar as atividades comerciais e administrativas da cidade, o que evidencia um processo de especialização funcional das áreas/bairros.

Na década de 30, face ao crescimento da cidade nas direções norte, sul (orla do Guaíba) e leste (surgimento de bairros como Petrópolis e Mont Serrat), surge a necessidade de instrumentos de coordenação das ações de ordenamento do espaço. Esboça-se um plano diretor na década de 30 através dos arquitetos Edvaldo Paiva e Luiz Arthur Ubatuba de Farias, mas foi somente nos anos 40 que apareceu o primeiro Plano Diretor, cuja preocupação central 
residia na abertura de grandes vias para a circulação. Para a efetivação do plano, foi

(...) necessário demolir toda uma parte do centro da cidade composta de antigos casarões no estilo colonial, além de um conjunto de habitações populares. Essas demolições terminaram por causar uma redução no número de habitações disponíveis no centro da cidade, gerando uma inflação nos aluguéis e a migração dos grupos de baixa renda para áreas mais distantes do centro da cidade (MONTEIRO, 2004, p. 57)

O crescimento da mecanização e da concentração fundiária no campo, a partir dos anos 50, provocou um êxodo rural de grandes proporções, trazendo para a cidade uma massa de população que, não encontrando empregos, incharam as periferias de Porto Alegre. Consolida-se, a partir desse período, o processo de metropolização da capital gaúcha, resultando em crescimento acelerado da população (Gráfico 1; Figura 1) e a conseqüente explosão da cidade em periferias e arrabaldes com reduzida infra-estrutura de iluminação, esgoto e água encanada. Paralelamente, o ideário de uma cidade moderna se difunde com a construção do aeroporto Salgado Filho, a verticalização da área central e a abertura de avenidas cada vez mais imponentes. Nesse contexto, elabora-se o Plano Diretor de 1959, mais complexo e abrangente do que o de 1943 em seus dispositivos de uso e regulação do solo urbano e planejamento da expansão da cidade ${ }^{61}$.

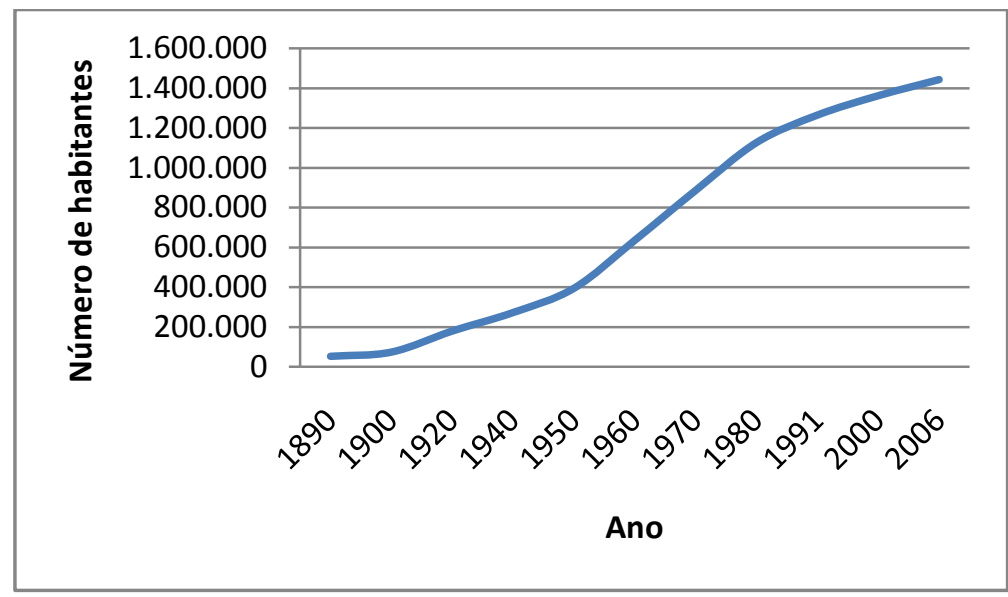

Gráfico 1 - Evolução da população residente em Porto Alegre (1890-2006). Fonte: IBGE.

61 Uma interessante descrição da evolução da cidade de Porto Alegre e de sua organização espacial na década de 1950 pode ser encontrada em Roche (1966). Um livro mais recente seria o de Souza \& Müller (2007). 


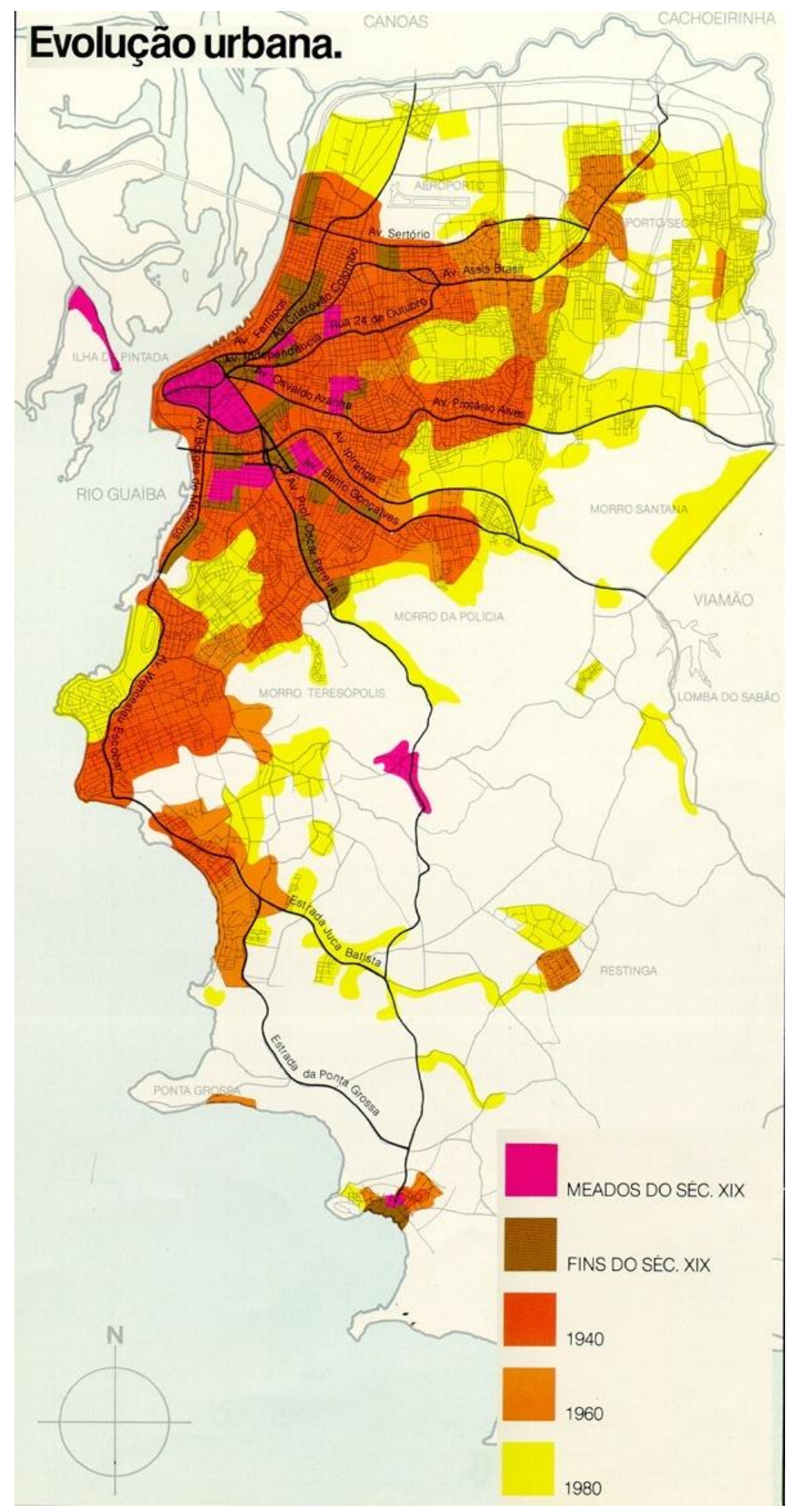

Figura 1 - Evolução urbana do município de Porto Alegre. Fonte: BIEV (Banco de Imagens e Efeitos Visuais da UFRGS) 
A evolução do mercado de terras conduziu a uma concentração progressiva das terras urbanas nas mãos de poucas empresas. Entre $1930 \mathrm{e}$ 1980, destacou-se a empresa Schilling \& Kuss Ltda., fundada por descendentes de imigrantes alemães originários do setor do comércio, posteriormente adquirida pela Máquinas Condor S.A. Essa empresa teve um papel extremamente importante no loteamento de bairros hoje caracterizados por uma ocupação de classe média e alta no que consideramos o eixo leste, como Petrópolis, Bela Vista, Chácara das Pedras e Três Figueiras - os dois últimos adjacentes ao Shopping Center Iguatemi (STROHAECKER, 2005).

Nos anos 70, sob a administração de Thompson Flores, Porto Alegre assistiu a mais uma rodada de modernização de sua infra-estrutura viária, com o alargamento de avenidas, construção de túneis e viadutos e destruição de prédios de caráter histórico. Consuma-se nesse período, com a industrialização mais intensiva, o processo de explosão da cidade, de transmutação da cidade em metrópole, cujos conteúdos essenciais se desencontram - e mesmo se opõem - com aqueles que definiam a cidade. Para Lefebvre, que comenta esse processo de envergadura inigualável na história das sociedades,

[...] something strange and wonderful was [...] taking place [...]: the non-city and the anti-city would conquer the city, penetrate it, break it apart, and in so doing extending it immeasurably, bringing about the urbanization of society and the growth of the urban fabric that covered what was left of the city prior to the arrival of industry (LEFEBVRE, 2003, p. 13-4) ${ }^{62}$.

Isso significou uma

[...] tremendous concentration (of people, activities, wealth, goods, objects, instruments, means and thought) of urban reality and the immense explosion, the projection of numerous, disjunct fragments (peripheries, suburbs, vacation homes, sattelite towns) into space (LEFEBVRE, 2003, p. 14) ${ }^{63}$.

A transformação da cidade em metrópole, que se efetiva entre 1960 e 1970 para o caso da capital gaúcha, define os novos conteúdos do processo de

\footnotetext{
62 "[...] algo estranho e extraordinário estava ocorrendo: a não-cidade e a anti-cidade estavam penetrando na cidade, despedaçando-a, e ao fazê-lo, estendendo-a desmesuradamente, acarretando a urbanização da sociedade e o crescimento do tecido urbano que cobriu o que sobrara da cidade anterior à chegada da indústria". Tradução nossa.

63 "[...] enorme concentração (de pessoas, atividades, riqueza, bens, objetos, instrumentos, meios e pensamento) da realidade urbana e a imensa explosão, a projeção de numerosos fragmentos apartados (periferias, subúrbios, segundas residências, cidades-satélite) no espaço". Tradução nossa.
} 
urbanização, o que significa que os problemas definidores da metrópole devem ser tratados sem respeito aos limites institucionais que fragmentam o espaço da metrópole em um conjunto de unidades territoriais de poder político e administrativo.

Uma apreciação do comportamento da "indústria imobiliária" nesse período revela-se bastante complicada, visto a escassez de informações mais específicas sobre o setor. Contudo, acreditamos ser possível ter alguma idéia do que se passava no que tange ao setor habitacional se atentarmos para algumas mudanças concernentes às políticas habitacionais e ao cenário macroeconômico do Brasil. Essas mudanças permitem-nos visualizar uma inflexão importante na oferta imobiliária ocorrida durante os anos 1980 e que, provavelmente, tenha seguido seu curso durante as décadas de 1990 e 2000, o que justifica a digressão.

Pelos motivos já expostos acima - qual sejam, o elevado dispêndio necessário e os níveis baixos de renda de grande parte da população - o setor de moradia sempre esteve preso à necessidade de crédito e de políticas habitacionais diversas. A universalização da habitação numa economia mercantil capitalista parece ser de fato impossível, mas sem a presença do Estado na promoção da habitação - em suas inúmeras formas de intervir - o problema se manifestaria de forma ainda mais acentuada. Não é intenção, aqui, resgatar toda a história das políticas de financiamento habitacional no País, mas compreender como, nos anos recentes, transformações nas condições de crédito habitacional imprimiram uma trajetória singular ao mercado imobiliário que se verificou, em maior ou menor intensidade, nas principais metrópoles do Brasil.

A entrada em cena do regime militar, em 1964, veio acompanhada da elaboração de uma política habitacional ampla, destinada a ampliar as condições de aquisição da casa própria para os setores de renda média e baixa da sociedade e facilitar o acesso ao crédito para as empresas do setor da construção. Para tanto, foi criado o Banco Nacional da Habitação (BNH), cuja função principal era zelar pela correta alocação dos recursos do Sistema Financeiro da Habitação (SFH) - recursos canalizados fundamentalmente do sistema de poupança e do Fundo de Garantia por Tempo de Serviço (FGTS). Como observa Botelho (2007, p. 110), as políticas de habitação desenvolvidas 
pelos governos autoritários possuíam uma visão empresarial segundo a qual as entidades de financiamento deveriam ser auto-sustentáveis, o que significa dizer que exigiam o retorno completo (amortização, juros e correção monetária) dos financiamentos concedidos - ainda que estivessem previstos subsídios aos setores de renda mais baixos. Essa postura empresarial logo resultou em obstáculos à política do $\mathrm{BNH}$, sobretudo devido à inadimplência nos setores de renda baixa (AZEVEDO, 1996). As Cooperativas Habitacionais (COHABs) acabaram direcionando suas iniciativas para setores de renda com menor risco de inadimplência, enquanto que muitos mutuários em dificuldade de quitação das dívidas venderam seus imóveis (AZEVEDO, p. 112-3). Com o passar dos anos, ficou evidente que todo o SFH havia atendido muito pouco os setores da população que mais necessitavam de habitação, que não poderiam contemplar sua lógica de racionalidade empresarial. Com a crise do início dos anos 1980, a lógica sobre a qual se assentava a política do BNH veio abaixo:

\begin{abstract}
No final dos anos 70 , mas principalmente ao longo da década de 80 , os recursos do SFH tornaram-se cada vez mais escassos, devido à crise econômica e ao desemprego observados no período. O efeito dessa crise foi a diminuição do recolhimento do FGTS e dos depósitos em poupança e o aumento dos saques do FGTS por parte dos trabalhadores, à medida que aumentava o desemprego. Por outro lado, aumentava também o número de inadimplentes, já que o aumento do desemprego desestabilizou o rendimento de muitas famílias e a inflação aumentou o valor das prestações corrigidas (BOTELHO, 2007, p. 118)
\end{abstract}

Com os problemas se acumulando, o BNH é extinto em 1986, seus recursos sendo repassados às caixas econômicas. Os efeitos desse colapso sobre os mercados imobiliários das metrópoles, e mais especificamente sobre o de Porto Alegre, são sentidos imediatamente. Depois de um crescimento observado em fins da década de 1970 e início da década de 1980, sobretudo em função de facilitação de acesso ao crédito, os mercados imobiliários de São Paulo, Rio de Janeiro e Porto Alegre experimentaram um declínio significativo nas variáveis de preço médio $/ \mathrm{m}^{2}$ e número de lançamentos ${ }^{64}$. A deterioração dos salários, o aumento na taxa de juros e declínio no número de financiamentos concedidos através do SFH, e o aumento da taxa de desemprego estiveram entre as razões desse declínio súbito e acentuado dos

${ }^{64}$ Cf. Ferraz Filho (1996). 
lançamentos de imóveis na capital gaúcha, que, de uma cifra de 9385 unidades lançadas em 1982, despencou para 1691 unidades lançadas em 1989 (Gráfico 2). Ainda que tenha havido uma recuperação econômica durante a década, o declínio nos financiamentos da casa própria e a instabilidade econômica permanente não permitiram uma recuperação da atividade imobiliária no período.

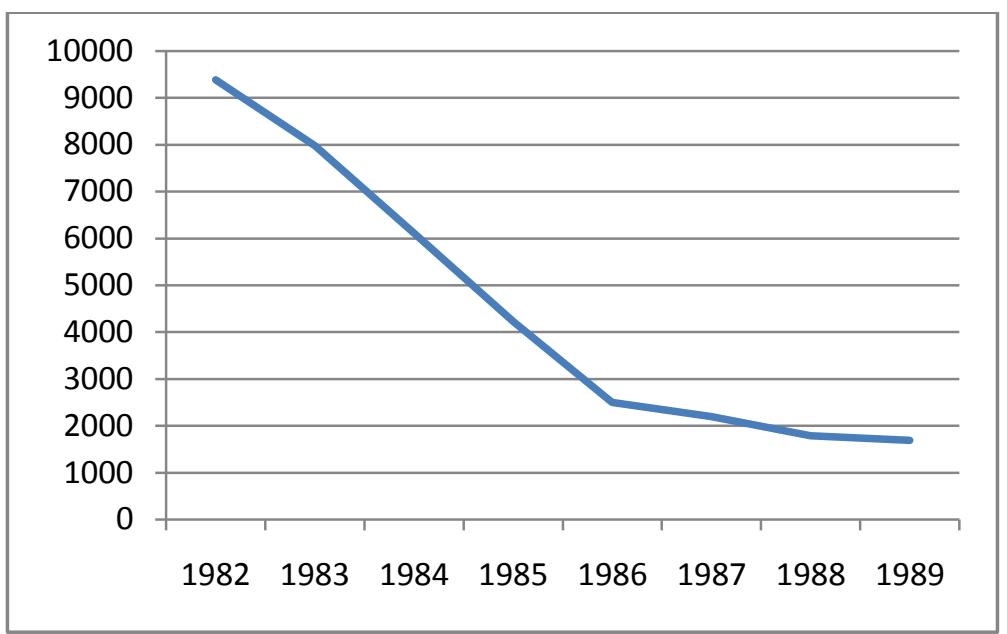

Gráfico 2 - Unidades lançadas no mercado imobiliário de Porto Alegre durante a década de 1980. Fonte: Rovatti (1990).

Mais importante do que a simples constatação de um declínio da atividade setorial durante a década de 1980, contudo, seria observar uma transformação importante no perfil da oferta. O que se pode verificar, ao atentarmos para o perfil da oferta na década, é que, prejudicados pelo declínio da demanda solvável em virtude da deterioração nas condições econômicas e de financiamento imobiliário, os capitalistas do setor restringiram a oferta imobiliária aos setores de renda mais alta, em condições de arcar com o custo elevado desta mercadoria sem recorrer - ou recorrendo em menor grau - ao crédito. É assim que pode ser explicado o aumento na área média dos lançamentos imobiliários (Gráfico 3), no preço médio das unidades a partir de 1985 e a alteração substancial na tipologia ofertada que resultou em uma predominância dos apartamentos de 3 dormitórios e coberturas (Gráfico 4). 


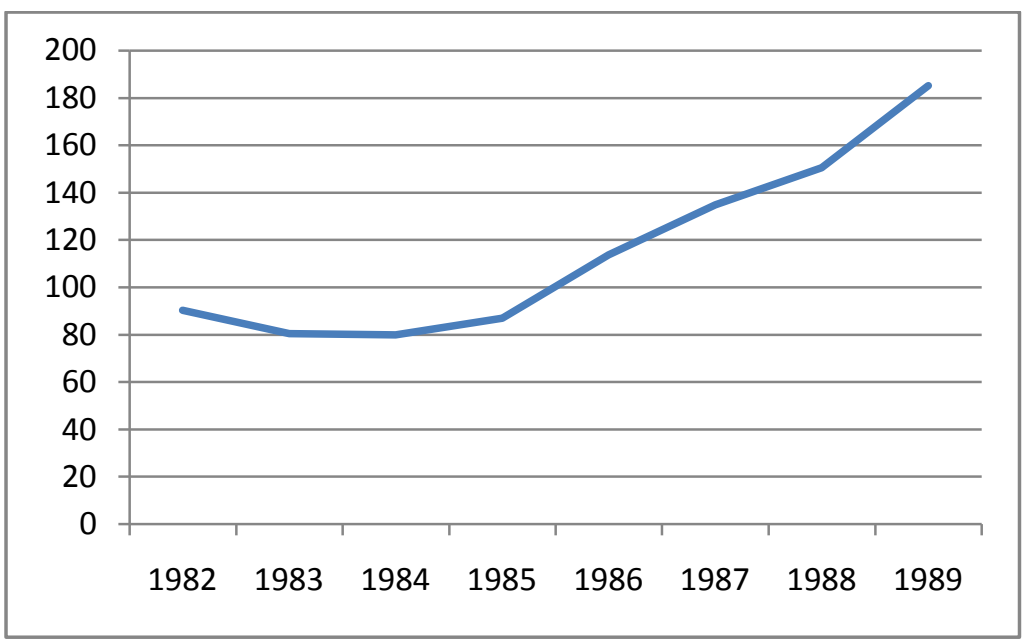

Gráfico 3 - Área média dos imóveis ofertados em Porto Alegre (em $\mathrm{m}^{2}$ ) na década de 1980.

Fonte: Rovatti (1990)

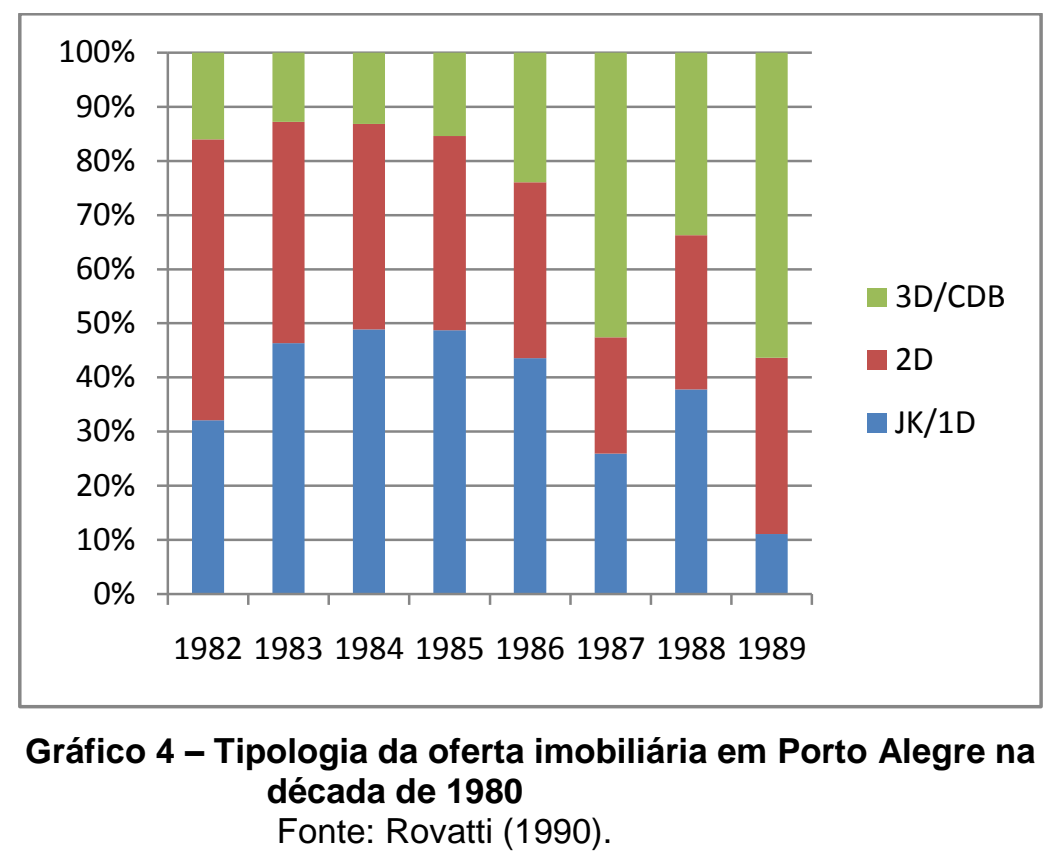

Os efeitos dessa alteração na capacidade da demanda solvável e, por conseguinte, na tipologia e na área média dos imóveis, se fizeram sentir, também, na distribuição espacial da oferta. A restrição da oferta imobiliária aos setores de renda mais elevada se traduziu, espacialmente, na concentração da oferta nos bairros mais valorizados da cidade que, em termos gerais, não se alteraram tanto entre 1980 e os dias de hoje - localizam-se, ainda, partindo do centro na direção leste e na direção sul (ROVATTI, 1990; ROVATTI, 1996).

A recuperação no desempenho do mercado imobiliário da capital gaúcha tardou a aconteceu. Embora haja uma lacuna de dados relativos a lançamentos 
e vendas no mercado imobiliário entre os anos de 1990 e $1993^{65}$, ao observamos a série histórica de unidades lançadas e unidades vendidas no mercado imobiliário de Porto Alegre a partir de 1994 (Gráfico 5), constatamos que os patamares do início dos anos 1980 (9385 unidades lançadas em 1982) ainda não foram atingidos. A observação do Gráfico 5 permite-nos constatar a continuidade, até 2005 , de patamares baixos de lançamentos e vendas de unidades no mercado imobiliário, com um leve aumento dos número a partir de 1998. Somente em 2006 é que se verifica um incremento substancial de unidades lançadas, representando um aumento superior a 100\% em relação ao ano anterior. Esse dado é corroborado com aquele da velocidade de vendas no mercado imobiliário, apresentado no Gráfico 6. Acreditamos que condições renovadas de financiamento imobiliário - ampliação dos prazos, diminuição dos juros, etc - estejam por trás de um recrudescimento da atividade do setor, que, além do mais, se verificou em várias capitais brasileiras. Retornaremos a esse ponto mais adiante. Primeiramente, tentaremos identificar, através do recurso a alguns dados, certos padrões de localização espacial dos investimentos recentes da indústria imobiliária em Porto Alegre, atentando para a configuração espacial resultante e para possíveis cenários futuros.

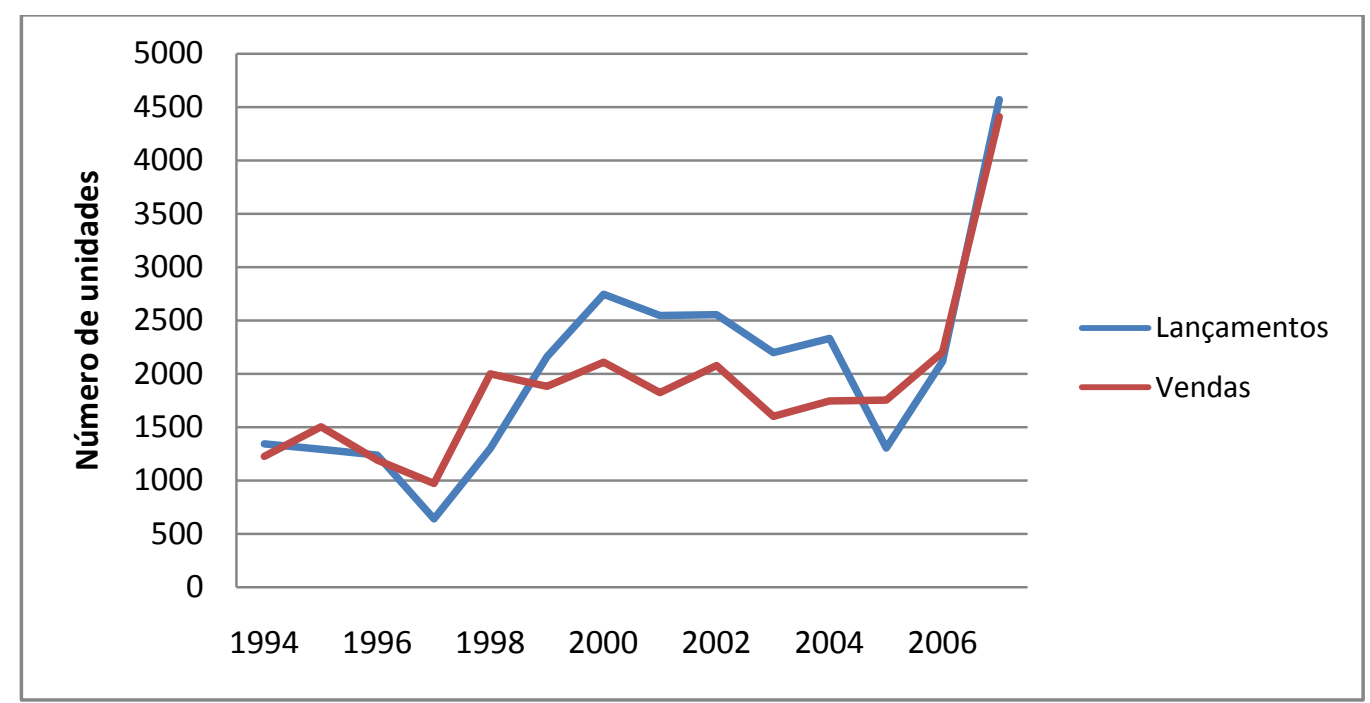

Gráfico 5 - Número de lançamentos e número de vendas no mercado imobiliário de Porto Alegre - 1994-2006

Fonte: Sinduscon/RS

${ }^{65}$ A empresa Avalien, que realizava pesquisas do mercado imobiliário nos anos 1980, deixou de desempenhar essa função em 1990, deixando uma lacuna em termos de levantamentos e pesquisas do mercado local. Essa lacuna foi aos poucos sendo preenchida pelas pesquisas desenvolvidas pelo Sindicato da Construção Civil (Sinduscon) do Rio Grande do Sul. 


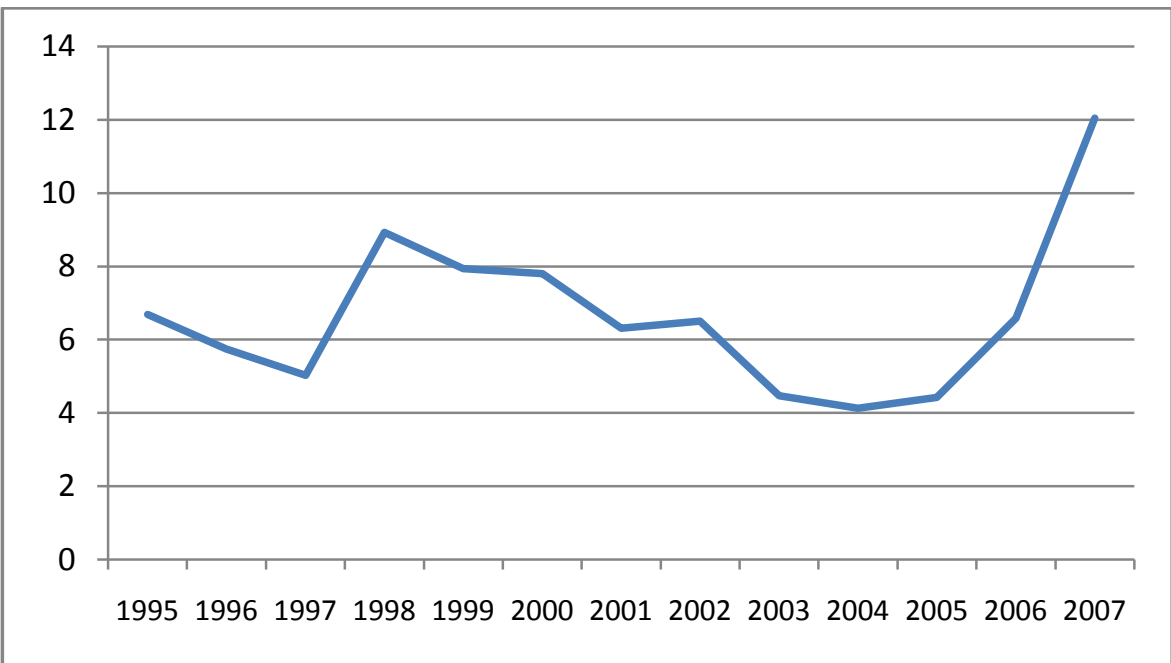

Gráfico 6 - Velocidade média anual de venda no mercado imobiliário de Porto Alegre (\%)

Fonte: Sinduscon/RS

Conforme já havíamos mencionado, a configuração espacial da capital gaúcha permite que identifiquemos um padrão segundo o qual as classes de renda mais elevada se deslocaram em dois sentidos, partindo do Centro: em direção a leste seguindo as áreas mais elevadas da cidade e em direção ao sul ao longo da borda do Lago Guaíba. É no interior desses dois eixos que se encontram as maiores possibilidades de valorização ao capital imobiliário. De fato, ainda que o preço da terra seja elevado nesses bairros, e portanto o custo da incorporação, a existência de uma demanda solvável permanente permite que os capitalistas do setor imobiliário estejam constantemente oferecendo novos produtos para atender a essa demanda. A pergunta que fica, e que procuraremos responder em certa medida, é a seguinte: se, como já constatamos, depois do declínio do BNH a oferta imobiliária se concentrou nas faixas de renda mais elevada, como é possível a reiterada oferta de imóveis para o mesmo setor de renda, sem que tenha havido um aumento de população ou um crescimento substancial das classes mais abastadas? Procuraremos responder a essa questão aos poucos, sem a pretensão de encontrar uma solução definitiva.

Por ora, o objetivo é identificar essa configuração espacial já mencionada. Para isso apresentamos os mapas 2, 3 e 4 abaixo. O Mapa 2 representa a renda média dos responsáveis pelo domicílio dos 78 bairros de 
Porto Alegre em 2000, de acordo com o Censo Demográfico do IBGE. Nesse mapa, verificamos uma importante concentração de bairros caracterizados como de renda média-alta (superior a 16 salários mínimos, representados na cor mais escura) na área central (centro-leste) - são eles Petrópolis, Bela Vista, Independência, Moinhos de Vento, Mont Serrat, Três Figueiras, Rio Branco, Chácara das Pedras, Farroupilha, Boa Vista e Higienópolis -, um bairro no que se costuma denominar zona norte - o bairro Jardim Lindóia - e três bairros na zona Sul - Vila Assunção, Pedra Redonda e Ipanema. O Mapa 4 destaca os bairros cuja renda média mensal dos responsáveis pelo domicílio supera 20 salários mínimos (restringindo, portanto, ainda mais em relação ao Mapa 2). Nele verificamos uma concentração de bairros na área centro-leste ( 9 bairros), um bairro na zona norte e dois bairros na zona sul.

Se observarmos o Mapa 3, que representa o preço médio de um apartamento usado de 3 dormitórios em Porto Alegre, verificamos uma semelhança bastante marcada com o Mapa 2. Observa-se, no Mapa 3, que os bairros cujo preço médio do apartamento de 3 dormitórios supera $\mathrm{R} \$ 250$ mil (área mais escura) são quase os mesmos cuja renda familiar supera os 16 salários mínimos. São eles: Independência, Moinhos de Vento, Rio Branco, Bela Vista, Petrópolis, Mont Serrat, Auxiliadora, Três Figueiras, Boa Vista, Higienópolis e Tristeza ${ }^{66}$.

Um outro mapa pode nos ajudar a corroborar com o padrão espacial encontrado nos mapas anteriores. O Mapa 5 diz respeito à porcentagem dos imóveis novos ofertados em 2007 que se situam na faixa acima de $\mathrm{R} \$ 300$ mil. Nesse mapa, quanto mais escuro um bairro, maior é a porcentagem da oferta que se situa na faixa de valor superior a 300 mil reais. Também nesse mapa o destaque fica para os bairros situados na região centro-leste e para dois bairros na zona sul. A Tabela 2, abaixo, ajuda a complementar o mapa, apresentando os 10 bairros cuja oferta de imóveis novos tem a característica estar concentrada em mais de $50 \%$ na faixa de valor acima de $\mathrm{R} \$ 300$ mil. Desses

\footnotetext{
${ }^{66}$ Deve-se frisar os limites do mapa de preço médio do apartamento. A amostragem é pequena em um certo número de bairros e, por isso, pode levar a algumas distorções, sobretudo porque, em determinado ano, a tipologia da oferta (metragem superior ou inferior, padrão da construção) pode distorcer para cima ou para baixo o valor médio dos apartamentos por bairro, problema que seria reduzido caso tivéssemos obtido dados relativos ao preço médio do metro quadrado. A ausência desse tipo de oferta para certos bairros (por exemplo, Vila Assunção), além disso, impede uma apreciação mais rigorosa do preço médio da terra.
} 
10 bairros, 3 circundam a área do Shopping Iguatemi (Três Figueiras, Passo da Areia e Boa Vista), que, segundo a hipótese a ser desenvolvida nesse trabalho, tem induzido a valorização imobiliária na direção leste, expandindo o eixo de valorização já consolidada identificado nos mapas 3 e 4.

Tabela 2 - Porcentagem da oferta acima de 300 mil reais -2007 .

\begin{tabular}{l|cc}
\hline Bairro & $\begin{array}{c}\text { Porcentagem da oferta de } \\
\text { imóveis novos situada na } \\
\text { faixa superior a } \$ \$ 300 \text { mil }\end{array}$ & $\begin{array}{c}\text { Rendimento médio } \\
\text { dos responsáveis } \\
\text { pelo domicílio em SM } \\
-2000\end{array}$ \\
\hline Moinhos de Vento & 90,5 & 29,33 \\
Três Figueiras & 81,5 & 37,00 \\
Vila Assunção & 77,1 & 27,74 \\
Boa Vista & 71,0 & 25,76 \\
Bela Vista & 67,8 & 34,68 \\
Passo da Areia & 66,6 & 9,96 \\
Rio Branco & 58,4 & 20,50 \\
Petrópolis & 55,7 & 20,37 \\
Ipanema & 51,7 & 16,94 \\
Santa Teresa & 50,0 & 5,78 \\
\hline
\end{tabular}

Fonte: Sinduscon/RS e IBGE.

O cotejo com os dados de rendimento médio mensal surpreende em dois casos, pela discrepância entre uma oferta de alto padrão e uma renda média familiar média-baixa registrada 2000: no do bairro Passo da Areia e no do bairro Santa Teresa. No último caso, a oferta de casas de alto padrão indica uma tendência à valorização do eixo que identificamos como Sul, mas de maneira mais tímida. A renda média familiar baixa, aqui, se explica pela existência de áreas de favela na encosta do morro Santa Teresa. O caso do Passo da Areia é diferente. Trata-se de um bairro que, de longa data, é ocupado por uma população de renda média e média-baixa, como evidencia a pesquisa de renda média relativa ao ano $2000^{67}$. O fato de que o bairro tem abrigado investimentos destinados a uma demanda nitidamente situada nos estratos de renda mais elevados aponta para a formação de uma nova

\footnotetext{
${ }^{67}$ Até certa data, como atesta a descrição da cidade feita por Jean Roche (1953), o bairro Passo da Areia foi de residência operária.
} 
centralidade de valorização imobiliária, possível em virtude da existência provável de um rent gap - diferença entre a renda da terra atual e a potencial na área situada ao norte do shopping Iguatemi. A valorização dos bairros Passo da Areia e Cristo Redentor recebeu atenção do principal jornal local (Zero Hora). Já em 2004, reportagem do jornal relatava uma valorização no Cristo Redentor da ordem de 15\% entre 2003 e 2004, tendo como referência o preço dos aluguéis ${ }^{68}$. Sobre o bairro Passo da Areia, reportagem de 2007 destaca a aceleração nas vendas no bairro, o que colocou o bairro entre os que têm maior número de unidades vendidas ${ }^{69}$. Entretanto, esse movimento de transformação do bairro Passo da Areia - e de outros situados a norte e leste do Iguatemi, como Cristo Redentor e Vila Ipiranga - só poderá ser devidamente observado nos próximos anos, com um aumento da renda média familiar do local e uma alteração na tipologia do estoque residencial.

\footnotetext{
${ }^{68}$ Zero Hora, Caderno Imóveis, 23/05/2004.
}

${ }^{69}$ Zero Hora, ZH Lindóia, 21/06/2007. 


\section{Rendimento médio mensal dos responsáveis pelo domicílio em Porto Alegre/RS - 2000}

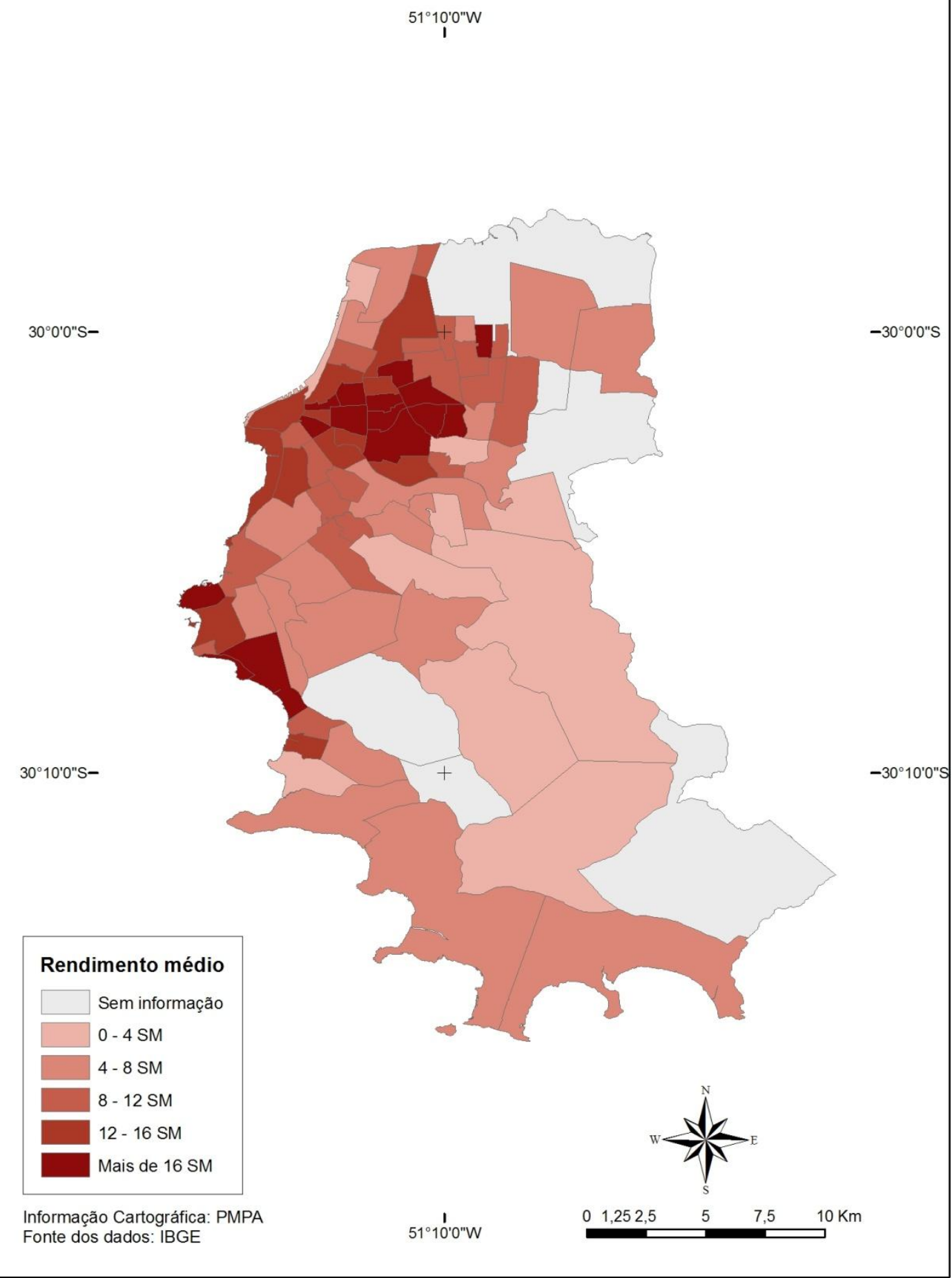

Mapa 2 - Rendimento mensal médio dos responsáveis pelo domicílio em Porto Alegre (2000). 


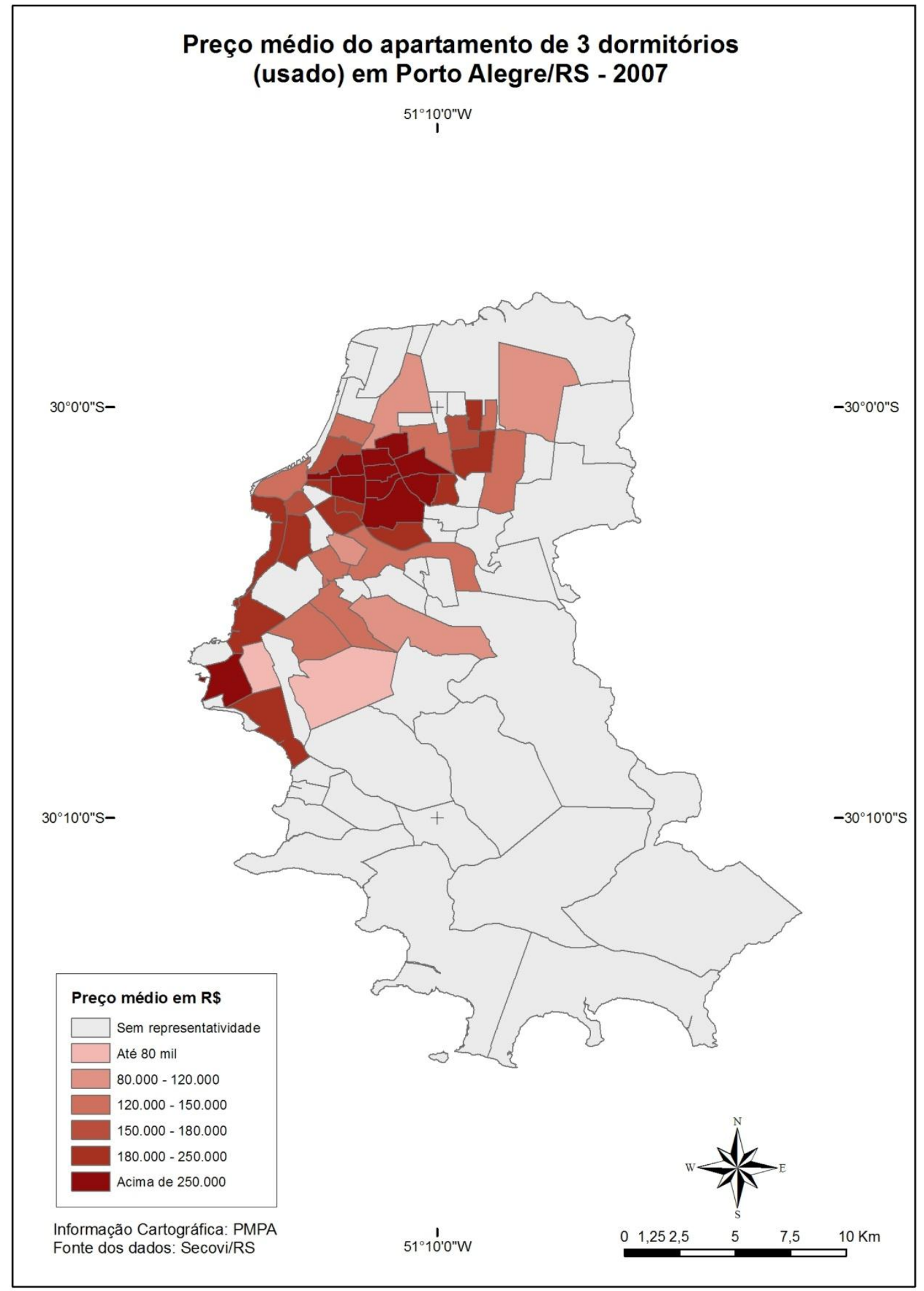

Mapa 3 - Preço médio, em reais, de um apartamento (usado) de 3 dormitórios em Porto Alegre. 


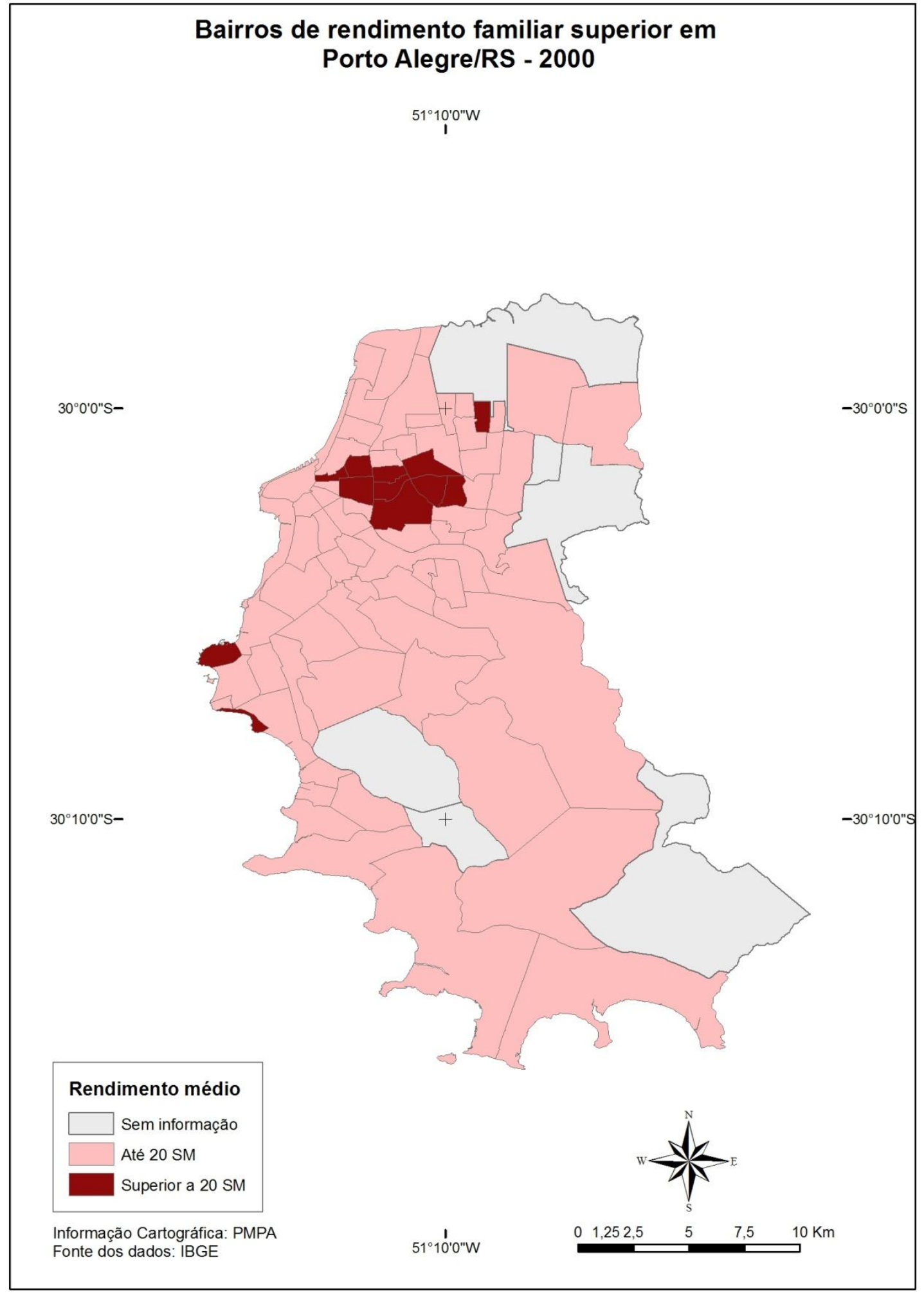

Mapa 4 - Bairros de rendimento familiar superior em Porto Alegre. 


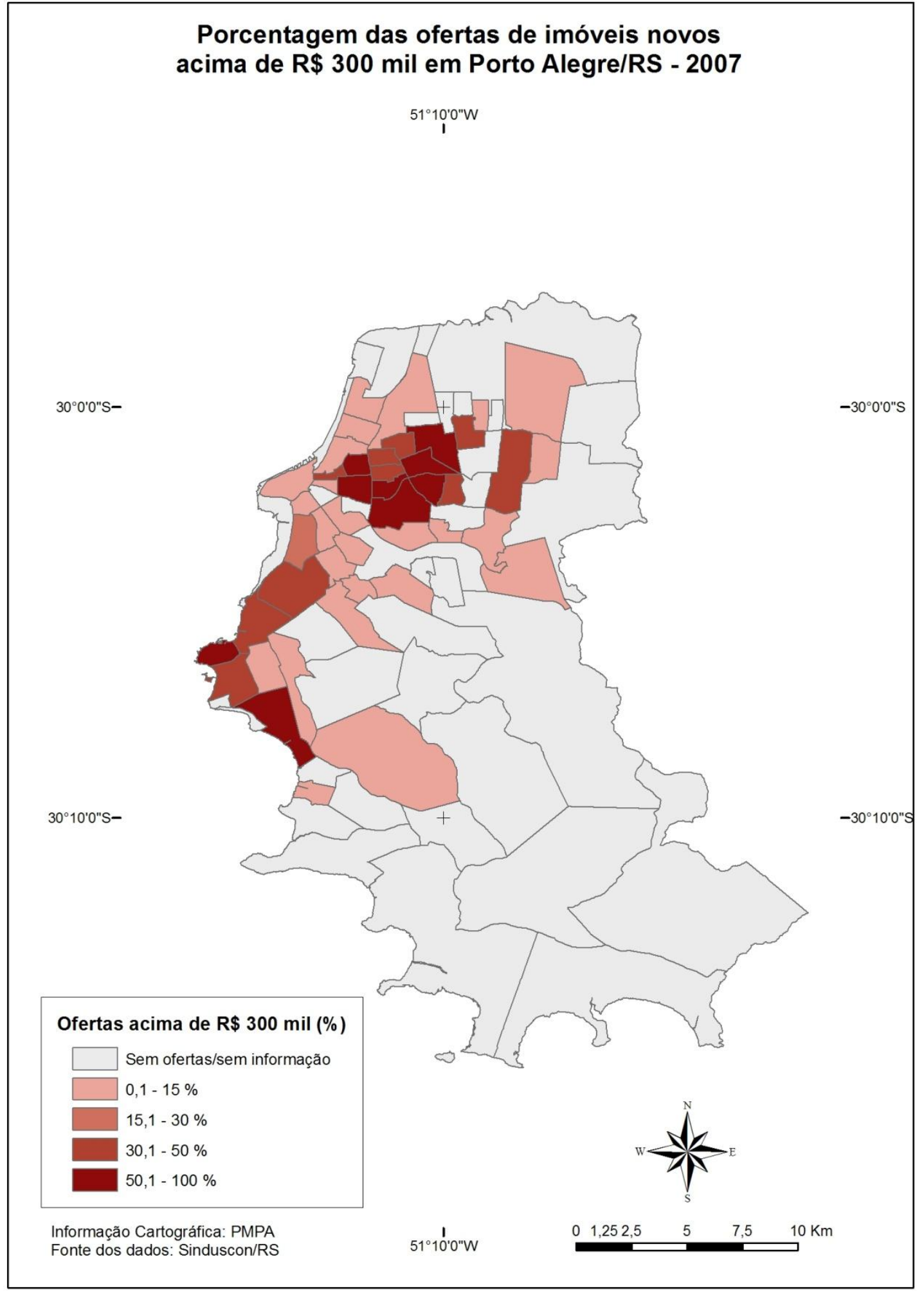

Mapa 5 - Porcentagem de imóveis novos acima de $\mathrm{R} \$ 300$ mil em Porto Alegre/RS. 
A hipótese de que existe uma nova fronteira urbana (centralidade imobiliária em vias de efetivação) no entorno do shopping Iguatemi, sobretudo nos bairros de Passo da Areia e Vila Ipiranga (comercializado, em sua parte adjacente ao Iguatemi, como "Jardim Europa"), ainda pouco valorizados, ganha suporte quando observamos, também, a distribuição espacial das ofertas de muito valor (acima de $\mathrm{R} \$ 705$ mil reais) ${ }^{70}$, apresentada no Gráfico 7 - sempre atentando, obviamente, para os limites de uma amostragem relativa a um ano. O que o gráfico mostra é que cinco bairros - Bela Vista, Passo da Areia, Rio Branco, Três Figueiras e Petrópolis - concentram a quase totalidade das ofertas de maior valor. Desses cinco bairros, somente o Passo da Areia não se encontra situado entre os de renda mais alta identificados anteriormente. Além disso, o preço do apartamento usado de 3 dormitórios também é menor aí do que em outros bairros mais tradicionais. A ausência do bairro Vila Ipiranga, onde constariam as ofertas do Jardim Europa, deve-se, provavelmente, ao período do levantamento (início de 2007), quando ainda não havia iniciado a comercialização dos apartamentos de valor mais elevado no novo bairro projetado.

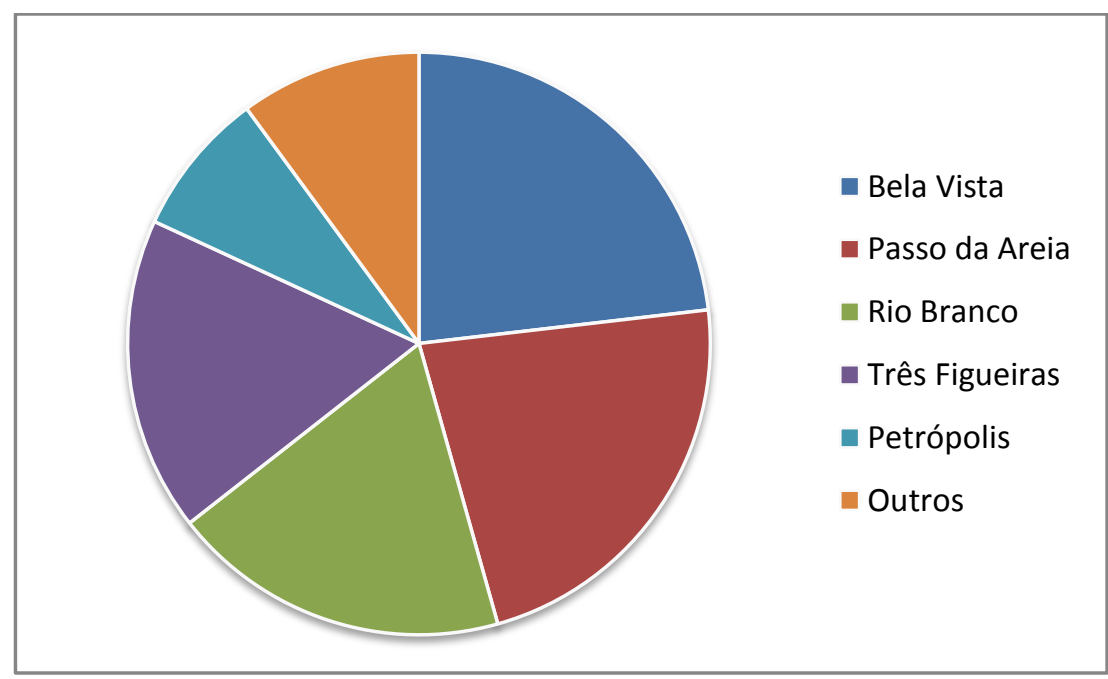

Gráfico 7 - Distribuição das ofertas acima de R\$ 705 mil em 2007 Fonte: Sinduscon/RS

\footnotetext{
${ }^{70}$ Procuramos nos ater à escala de valores estabelecida pelo Censo do Mercado Imobiliário do Sinduscon. Na publicação referente ao ano de 2007, a oferta de imóveis novos está dividida em 11 faixas de valor. Tomamos aqui as duas faixas de valor superiores (de 705 a 935 mil e acima de $935 \mathrm{mil}$ ) para construir o gráfico.
} 
Com todas as ressalvas necessárias, que explicitaremos a seguir, convém apresentar outro dado representativo da oferta imobiliária. A Tabela 3 lista o número médio de unidades por empreendimento em 2006 e 2007. Esse dado é importante visto que números mais elevados indicam a presença de empreendimentos de maior porte, geralmente ofertados por construtoras de ponta. Os dados, contudo, podem sofrer distorções, visto que estamos diante de uma relação entre "unidades novas em oferta" e "empreendimentos novos em oferta". Pode acontecer, então, que certos empreendimentos novos tenham somente 1 unidade em oferta, porque todas as outras já foram vendidas. Isso distorceria os dados para baixo, ao passo que um empreendimento novo em que nenhuma unidade foi vendida teria o efeito oposto. Acreditamos que esse problema possa ser mitigado ao selecionarmos somente os bairros que apresentaram, em ambos os anos, mais de 100 unidades (apartamentos/casa) ofertadas. Haveria, então, um equilíbrio semelhante em todos os bairros, o que autorizaria a comparação: um certo número de empreendimentos teriam quase todas unidades já vendidas, outro porcentual de empreendimentos apresentariam um número elevado de ofertas, etc. Obviamente, um bairro em que se observasse um declínio abrupto das vendas de unidades teria uma média elevada de unidades/empreendimento. Mas esse problema também pode ser contornado quando observamos que todos os bairros selecionados tiveram um porcentual de velocidade de vendas alto, o que significa que esse tipo de distorção (um número elevado de unidades não vendidas) dificilmente deve acontecer. Por fim, é preciso assinalar que os dados disponíveis incluem unidades residenciais e comerciais. Assim, é possível que a existência de um elevado número de imóveis comerciais ocasione um aumento do número médio de unidades por empreendimento do bairro, visto que os empreendimentos comerciais (edifícios de escritórios, centros comerciais, etc) soem apresentar um número elevado de unidades. Por esta razão, apresentamos, na terceira coluna da Tabela 3, o porcentual de unidades comerciais em 2007. 
Tabela 3 - Média de unidades por empreendimento em 2006 e 2007.

\begin{tabular}{l|ccc}
\hline Bairro & 2006 & 2007 & $\begin{array}{c}\text { Porcentagem de } \\
\text { unidades } \\
\text { comerciais }\end{array}$ \\
\hline Bela Vista & 6,9 & 7,1 & $0 \%$ \\
Centro & 27,2 & 28,6 & $0 \%$ \\
Chác. das Pedras & 27,2 & 33,2 & $13,8 \%$ \\
Cristo Redentor & 21,5 & 20,0 & $0 \%$ \\
Higienópolis & 9,6 & 13,7 & $6,5 \%$ \\
Jardim Botânico & 15,3 & 18,2 & $0 \%$ \\
Jardim Itu Sabará & 11,9 & 12,9 & $0 \%$ \\
Jardim Lindóia & 17,9 & 21,4 & $28,0 \%$ \\
Menino Deus & 16,8 & 10,2 & $0 \%$ \\
Mont Serrat & 11,6 & 12,2 & $0 \%$ \\
Passo da Areia & 19,9 & 24,0 & $0 \%$ \\
Petrópolis & 9,9 & 8,1 & $5,0 \%$ \\
Rio Branco & 11,3 & 11,0 & $0 \%$ \\
Santana & 19,1 & 12,4 & $0 \%$ \\
Tristeza & 12,7 & 10,4 & $0 \%$ \\
\hline
\end{tabular}

Fonte: Sinduscon/RS

A Tabela 3 é interessante pelo fato de apontar que os bairros situados nas adjacências do Shopping Center Iguatemi, marcados em vermelho, estão entre aqueles com maior média de unidades por empreendimento. De fato, somente o Jardim Lindóia e o Centro possuem números de grandeza semelhante aos três bairros destacados, sendo que o Jardim Lindóia possui grande proporção do estoque na forma de unidades comerciais. Trata-se, portanto, de um indicativo importante de que as grandes incorporadoras, que costumam ofertar empreendimentos de maior porte, têm-se interessado por investir na área. Voltaremos adiante à questão da atuação das grandes incorporadoras/construtoras na configuração recente do espaço urbano de Porto Alegre. Retornaremos, também, a refletir sobre a valorização nas

"Os dados relativos ao Jardim Itu Sabará são, aqui, a soma do que no Censo do Mercado Imobiliário, do Sinduscon, aparece como Jardim Itu Sabará e Jardim Planalto. Isso se deve ao fato de, oficialmente, o bairro Jardim Planalto pertencer ao Jardim Itu Sabará. 
adjacências do shopping Iguatemi no capítulo seguinte, quando exploraremos o surgimento do projeto Jardim Europa proposto pela incorporadora Goldsztein S.A.

Para finalizar o capítulo, procuraremos interpretar algumas informações que julgamos necessário mapear. A primeira diz respeito à densidade de oferta de imóveis novos por bairro institucional. $\mathrm{O}$ índice de densidade de oferta foi elaborado através de um cálculo que relaciona o número total de unidades novas em oferta com a área, em $\mathrm{km}^{2}$, do bairro no qual se encontram as ofertas. Julgamos tratar-se de um procedimento necessário em virtude da grande variação, em termos de área, dos bairros oficiais de Porto Alegre. Essa variação é significativa, por exemplo, para o caso do bairro Petrópolis, que há 7 anos apresenta o maior número de unidades ofertadas. Essa informação fica relativizada uma vez que reconhecemos que o bairro Petrópolis possui uma área bem superior a todos os bairros situados em suas adjacências (Bela Vista, Três Figueiras, Santa Cecília, etc). Em termos de densidade de ofertas, portanto, o bairro Petrópolis já não se situa como o de maior índice, ao menos nos dois anos selecionados.

O primeiro mapa (Mapa 6), então, espacializa o índice de densidade de oferta por bairros relativo ao ano de 2005. Nele observamos o predomínio da configuração espacial dos mapas anteriores, em que o índice de ofertas é superior nos bairros dos eixos valorizados centro-leste e sul - destaque para os bairros Petrópolis, Bela Vista, Higienópolis, Moinhos de Vento e Menino Deus, todos com um índice superior a 200 ofertas por $\mathrm{km}^{2}$. Entretanto, observamos que certos bairros fora desse eixo mais valorizado também apresentam uma densidade de ofertas significativa. Entre eles, destacaríamos os bairros Jardim Botânico, Santana, Cidade Baixa e, nas proximidades do shopping Iguatemi, Passo da Areia e Cristo Redentor. Um outro aspecto digno de nota é a existência de uma oferta relativamente significativa em bairros distantes e de valor da terra mais baixo como o Sarandi. O segundo mapa de densidade de ofertas (Mapa 7) refere-se ao ano de $2007^{71}$. Existem apenas sutis diferenças entre os dois mapas. Uma primeira diferença remete ao declínio de ofertas no

\footnotetext{
${ }^{71}$ Optamos por deixar como uma lacuna o ano de 2006 pelo fato de que os dados do Censo do Mercado Imobiliário levantam o total de imóveis novos em oferta. Isso significa que, se um apartamento novo não é vendido em um ano, ele constará no Censo de dois anos seguidos. A separação por dois anos atenua, embora não elimina por completo, esse problema.
} 
bairro Moinhos de Vento que, além de estar entre os mais valorizados da cidade, talvez seja aquele cuja atratividade simbólica é mais forte (signo de status social). Ao que tudo indica, o declínio no número de ofertas nesse bairro deve-se à dificuldade de encontrar terrenos passíveis de incorporação, uma vez que o Moinhos de Vento situa-se entre os bairros mais densamente ocupados, manifestando o fenômeno da "raridade do espaço" (CARLOS, 2001) no âmbito do desenvolvimento da metrópole ${ }^{72}$. Esse obstáculo, somado ao preço elevado da terra, vem afetando cada vez mais as iniciativas de investimento do capital imobiliário no eixo mais valorizado da cidade. Um segundo aspecto a ser salientado é a presença mais forte dos bairros Jardim Botânico e Passo da Areia, ambos apresentando um aumento significativo na densidade de ofertas. A presença relevante também é observável no caso da Cidade Baixa, com densidade de ofertas acima de 100 unidades por $\mathrm{km}^{2}$. Por fim, verifica-se uma presença mais forte em densidade de ofertas nos bairros mais afastados. Na Zona Norte, o bairro Anchieta, nas proximidades do Aeroporto Salgado Filho, e na área Leste os bairros Passo das Pedras e Jardim Itu Sabará.

Antes de apresentar a atividade recente das principais incorporadoras e interpretar as causas das transformações descritas, caberia apresentar um mapa (Mapa 8) que espacializa o número total de unidades vendidas entre março de 2006 e dezembro de 2007. É preciso frisar que aqui os dados são absolutos, ao contrário do que ocorreu nos mapas 6 e 7, em que os dados são relativizados pela área dos bairros. O que observamos é um padrão diferente em que, ainda que os bairros de valorização consolidada continuem com elevado número de vendas, bairros mais afastados desse eixo centralizado apresentaram um número elevado de vendas. Entre os bairros que merecem destaque estão o Partenon (1044 unidades vendidas), o Passo da Areia (813 unidades vendidas) e o Rubem Berta (558 unidades vendidas). Embora não tenhamos a discriminação tipológica das unidades vendidas, acreditamos que 0 elevado número de vendas nos três bairros tem origens distintas. O caso do Partenon deve-se, provavelmente, ao início das vendas de um grande

\footnotetext{
72 Nas palavras da autora, "o fenômeno da raridade se concretiza pela articulação de três elementos indissociáveis: a existência da propriedade privada da terra, a centralidade da área e o grau de ocupação (índice de construção) da área no conjunto do espaço da metrópole (Carlos, 2001, p. 175).
} 
empreendimento imobiliário realizado pela Capa, uma das construtoras de maior prestígio no mercado residencial de Porto Alegre. O empreendimento possui três torres residenciais com apartamentos a preços mais moderados (até $\mathrm{R} \$ 150 \mathrm{mil}$ ) do que os que costumam ser ofertados pela mesma construtora, evidenciando a intenção dessa construtora de atingir segmentos de renda diferentes. Já as ofertas no bairro Passo da Areia, como já foi visto, se situam em faixas de valor bastante elevadas e o fato desse bairro figurar como o segundo em número de vendas testemunha o crescimento do interesse a ele dirigido pelas empresas do setor imobiliário. 


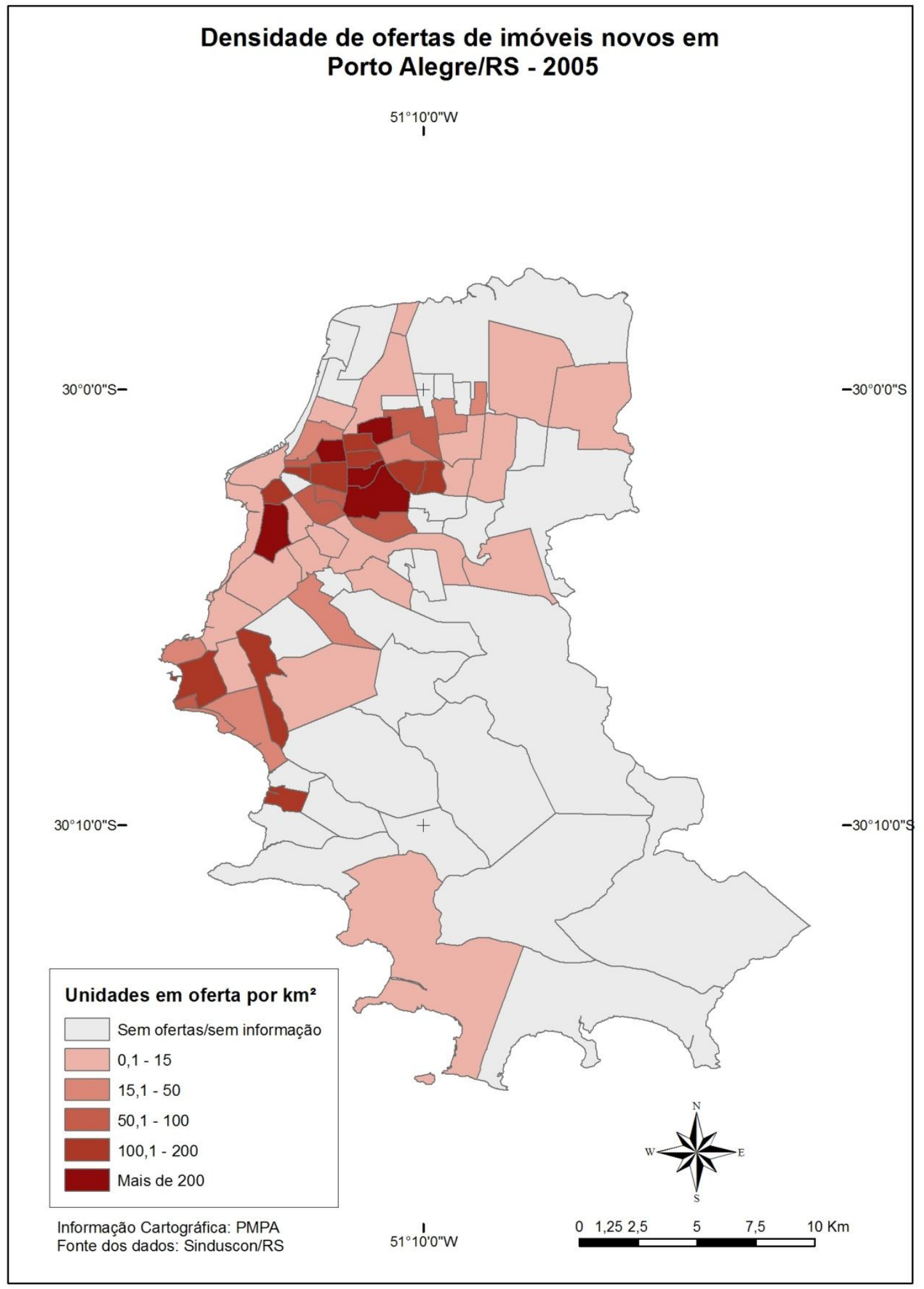

Mapa 6 - Densidade de ofertas por bairro em Porto Alegre/RS (2005) 


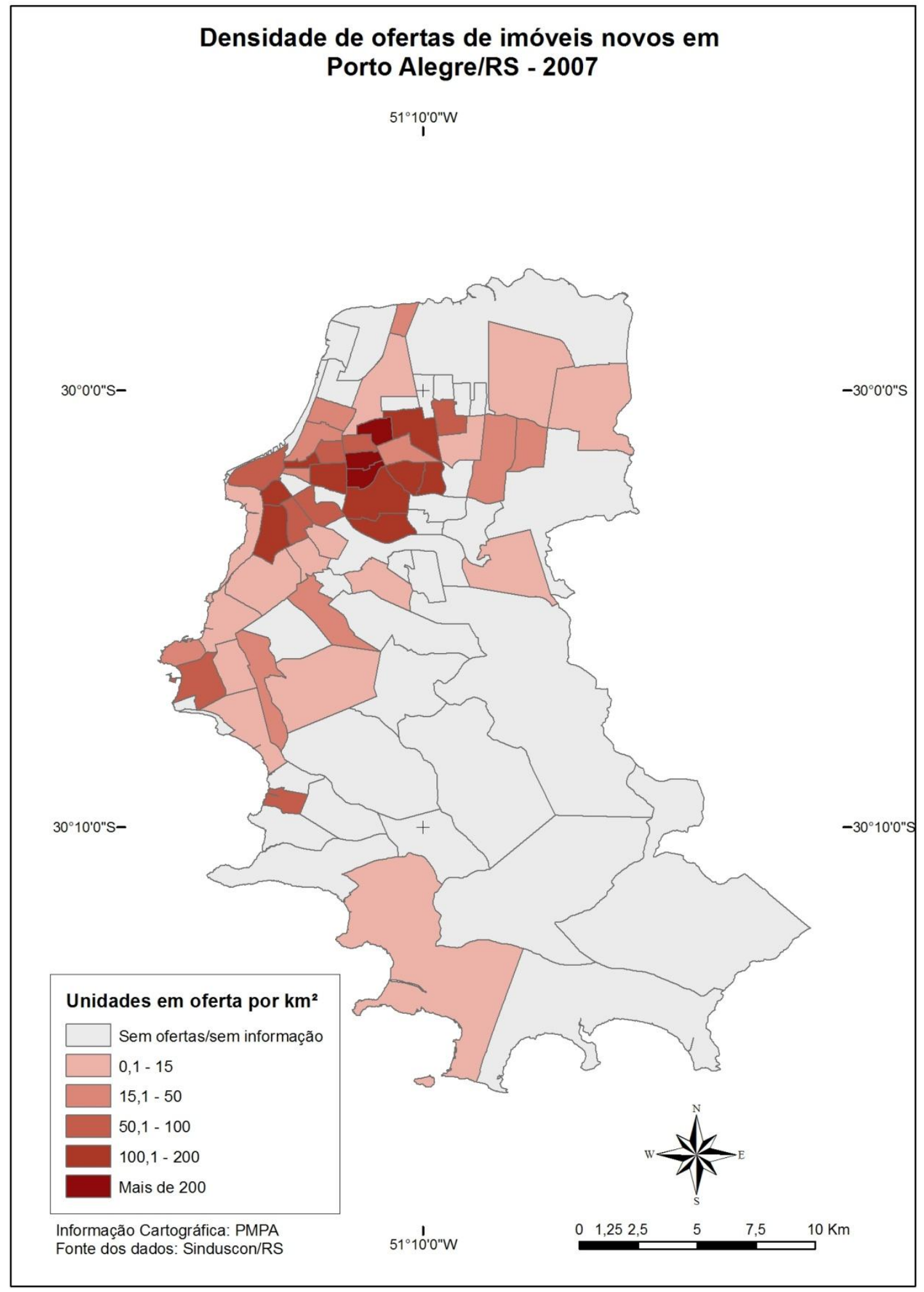

Mapa 7 - Densidade de ofertas por bairro em Porto Alegre (2007). 


\section{Unidades vendidas entre março de 2006 e dezembro de 2007 em Porto Alegre/RS}

$30^{\circ} 0^{\prime} 0 \mathrm{~S}-$

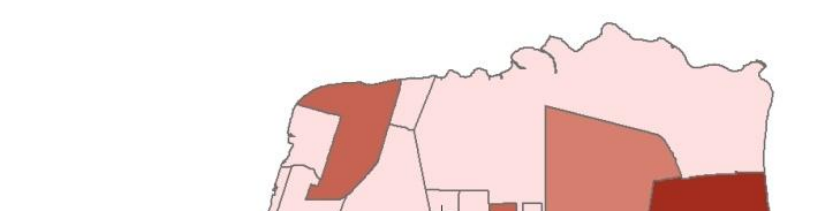

$30^{\circ} 10^{\prime} 0 " \mathrm{~S}-$

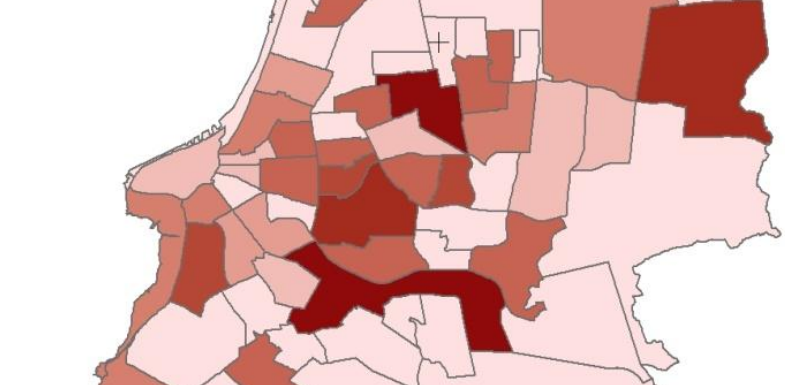

\section{Unidades vendidas}

\begin{tabular}{|l|l}
\hline & $0-15$ \\
\hline & $15-30$ \\
& $30-50$ \\
50 & -100 \\
$100-200$ \\
\\
\hline \\
$200-350$ \\
$350-600$ \\
\hline \\
\hline
\end{tabular}

Informação Cartográfica: PMPA

$51^{\circ} 10^{\prime} \cdot 0^{\prime \prime W}$

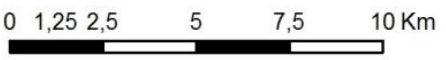

Mapa 8 - Unidades vendidas por bairro entre março de 2006 e dezembro de 2007. 
O mapa final (Mapa 9) talvez seja o que ofereça melhores condições de sustentar algumas das considerações feitas durante o trabalho, embora, assim como os anteriores, sofra de algum grau de generalidade que, em alguma medida, limita a possibilidade de conclusões mais sólidas. O mapa consiste em uma tentativa de representar as estratégias espaciais de algumas das incorporadoras mais importantes do setor na cidade. Todas as cinco construtoras selecionadas para compor o mapa estão, segundo levantamentos recentes, entre as que mais lançaram empreendimentos no município. É preciso ser dito, todavia, que a escolha especificamente das cinco resultou, em grande medida, do acesso que conseguimos obter às informações relativas ao endereço dos lançamentos de 1998 a 2008 e ao tipo de imóvel lançado. Em razão, talvez, de um fruto do acaso, acabamos por nos deparar com uma seleção de empresas que tem um potencial de representatividade importante. Isso porque, das cinco empresas, temos duas que voltam suas atenções fundamentalmente ao mercado de alta renda (Melnick e CFL); duas cuja meta de atuação tende a abranger tanto os mercados de alta quanto de "baixa" renda (Goldsztein e Capa), sendo esta uma opção recente e que resulta de parcerias com empresas de São Paulo; e, por último, uma empresa de fora, a Rossi, com sede em São Paulo, que tem por foco o mercado de média e "baixa" renda, ainda que não descarte atuar no segmento de alto padrão, e que atua de forma independente na cidade desde 2001.

Comecemos observando a atividade das duas empresas que caracterizam-se por atender o mercado de alta renda: CFL e Melnick. Observamos no mapa que tratam-se de empresas de tamanho médio, que não ofertam mais do que três empreendimentos por ano (uma média de 100 a 150 unidades) e que, do ponto de vista da localização espacial dos seus lançamentos, apresentam uma concentração ímpar nas seções mais valorizadas dos bairros Mont Serrat e Bela Vista. A Melnick, por exemplo, lançou 16 empreendimentos residenciais verticais entre 1998 e 2008 - dois deles em parceria com a Rossi, ainda inconclusos, e que optamos por colocar na relação de empreendimentos da Rossi - e, entre esses 16, 12 situam-se nos bairros Bela Vista e Mont Serrat. O padrão é semelhante para a CFL. A empresa lançou 15 empreendimentos residenciais verticais entre as duas datas, sendo que 9 situam-se nos dois bairros prediletos também da Melnick. 
Cumpre observar, contudo, que as duas empresas realizaram um movimento semelhante nos últimos anos: optaram também por investir na área próxima ao shopping Iguatemi, ainda que nas áreas de valorização mais consolidada dessa região. A CFL já lançou em 2006 um edifício no bairro Três Figueiras, possui mais dois em construção no mesmo bairro e ainda possui outro em construção no bairro Boa Vista. A Melnick, por sua vez, beneficiou-se da parceria com a Rossi, que optou por essa forma de atuação no mercado de alta renda. A parceria possui dois edifícios em construção, um deles na Av. Nilo Peçanha, no bairro Três Figueiras. O que observamos é que ambas as empresas possuem um perfil de investimento mais seguro (mais "conservador", como costuma se dizer no mundo dos negócios), destinado ao mercado de alta renda nos bairros mais tradicionais que gozam de um prestígio simbólico que faz as vezes da publicidade. Ainda assim, as duas empresas resolveram avançar suas atividades para a área próxima aos shoppings Iguatemi e Bourbon, ainda que, também, na parte mais nobre e consolidada da área, o bairro Três Figueiras. A especialização em termos de localização e de tipologia de oferta de empreendimento é a marca distintiva das duas empresas ("Líder em alto padrão", diz o slogan da Melnick).

A Goldsztein é a que teve maior poder de mercado das cinco empresas avaliadas, lançando um total de 51 empreendimentos entre 1998 e 2008, uma média aproximada de 5 por ano. Essa incorporadora apresenta um padrão espacial de investimentos bem menos concentrado quando comparada com as duas anteriores. Por volta de 40\% (20 empreendimentos) da oferta total da Goldsztein nesses dez anos situou-se nos bairros, identificados no Mapa 4, de renda média mensal mais elevada em 2000. É importante observar, para os objetivos da presente pesquisa, a tendência visível da empresa de atuar, nos anos recentes, na área próxima aos shoppings Iguatemi e Bourbon, mas não apenas nos bairros mais nobres da área, como também na área em que estamos considerando como o principal eixo de expansão da valorização imobiliária: os bairros Passo da Areia, Vila Ipiranga e Cristo Redentor. Também é digno de nota o conjunto de empreendimentos destinados a uma classe média baixa no bairro Jardim Carvalho, iniciado já na década de 1990 em uma área que ao redor do Parque Marcos Rubin. É importante salientar que aí 
também o parque desempenha papel destacado nas estratégias de venda da Goldsztein, assim como no caso do Jardim Europa

A Capa, por sua vez, revela uma presença importante no bairro Menino Deus que, nos anos recentes, também tem sido alvo de interesse por parte de grandes construtoras em função de seu potencial de valorização, o que ficou visível nos mapas anteriores. Dos 24 empreendimentos lançados pela empresa no período, 10 foram nesse bairro. É interessante observar, outrossim, que, com exceção de um único lançamento em 2001 no bairro Boa Vista, a empresa ainda não havia lançado empreendimentos na região que vamos estudar mais adiante. O empreendimento Terra Nova Vista Alegre, no bairro Vila Ipiranga marca o início de um interesse da empresa por investir na região, e sua publicidade ressalta, entre outras coisas, a proximidade com os shoppings já citados. Esse empreendimento e o empreendimento Terra Vista Nature, no bairro Partenon - cuja rapidez das vendas de suas mais de 1000 unidades deu ao Partenon um destaque no Mapa 7 -, são frutos de um redirecionamento da oferta da empresa para atingir a fatia de mercado representada por segmentos de renda médio-baixos, meta que é o cerne da parceria da empresa com a Rodobens Negócios Imobiliários.

A Rossi, por fim, entrou de maneira independente no mercado local já em 2001 e lançou seu primeiro condomínio vertical, em 2002, no bairro Sarandi. A empresa já realizou diversos empreendimentos destinados a segmentos de renda médio-baixos nessa região da cidade e continua atendendo esta fatia de mercado - o empreendimento no bairro Humaitá, em construção, segue o mesmo perfil. A Rossi ainda realizou comparativamente poucos investimentos na região de expansão de valorização que estamos abordamos, mas a construção de uma torre de escritórios pela empresa em 2005, em frente ao shopping Iguatemi, e a instalação de seu escritório local nesse edifício certificam um interesse da empresa em expandir suas atividades em direção a esta área. 


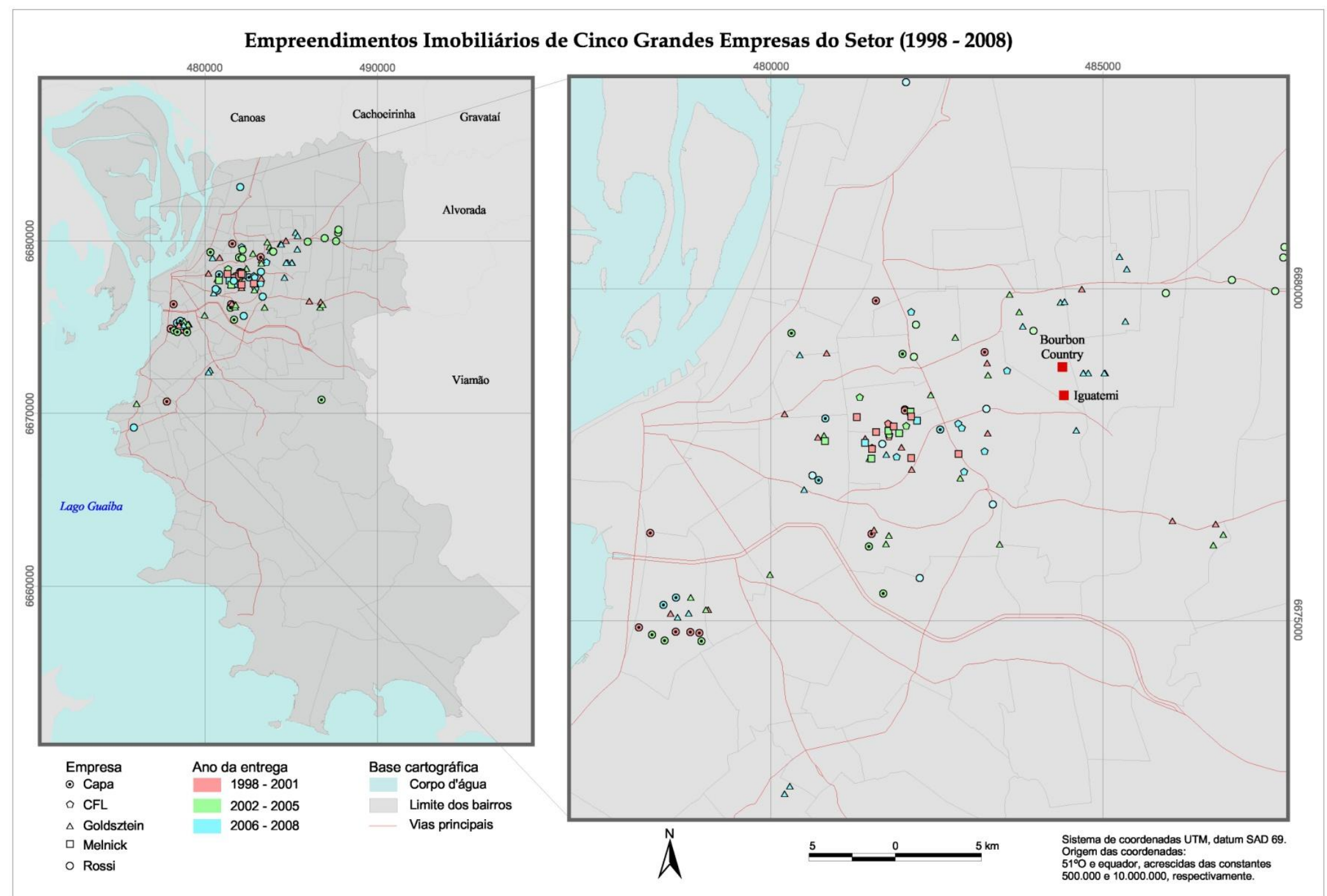

Mapa 9 - Atividades imobiliárias de grandes empresas do setor em Porto Alegre. 
Pode-se concluir, pela visualização do mapa acima, que as empresas envolvidas no setor imobiliário elaboram estratégias diferenciadas para apropriação do lucro de incorporação no espaço urbano. Ainda assim, verificase uma tendência, nos anos recentes, a uma dispersão dos investimentos por bairros menos próximos do eixo valorizado da cidade, o que resulta, como veremos logo abaixo, de uma expansão do financiamento ao imóvel. Esses investimentos mais dispersos atendem a uma fatia de mercado que ficou prejudicada por mudanças estruturais do financiamento imobiliário a partir dos anos 1980. Além disso, nota-se que a região próxima aos shoppings Iguatemi e Bourbon vem recebendo uma série de investimentos. Mas, ao contrário das incorporações mais distantes, muitos desses empreendimentos mais próximos aos shoppings atendem a um segmento de mercado de média e alta renda, que, como veremos adiante, tem sido atraído para o local em função de estratégias bastante refinadas das empresas de incorporação para apropriar-se da renda potencial disponível nessa fronteira urbana.

Essa aceleração da atividade imobiliária verificada em Porto Alegre, bem como os padrões espaciais impressos na paisagem metropolitana por esses investimentos, deve-se muito a alterações no ambiente econômico nacional, sobretudo no que se refere às condições de financiamento imobiliário. O início de uma transformação substantiva nas políticas de crédito tem sido exaltado por empresas e organizações setoriais como uma nova fase de acumulação. No seu Boletim Econômico, publicado duas vezes ao ano, o Sinduscon-RS, por exemplo, ressalta que,

com base na crescente ampliação do volume de oferta de financiamentos concedidos no âmbito do SBPE que, segundo dados divulgados pela $A B E C I P$ atingiu $R \$ 12,1$ bilhões nos últimos doze meses acumulados entre julho de 2006 e junho de 2007 (...), são bastante animadoras as perspectivas para a cadeia de negócios da indústria imobiliária em 2007.

E, em seguida:

Todavia, as condições de oferta podem melhorar ainda mais se, por exemplo, o prazo de amortização for ampliado para até 30 anos, com o financiamento cobrindo até $100 \%$ do valor do imóvel, taxa de juros de $7 \%$ com prestações fixas e com a desburocratização na concessão de crédito e a padronização de contratos de financiamento ${ }^{73}$.

${ }^{73}$ SINDUSCON-RS. Boletim Econômico. Porto Alegre, v. 1, 2007. 
De fato, as condições renovadas que animam os investidores do setor são marcantes. Depois de um emaranhado de dificuldades que se sucederam à crise do $\mathrm{BNH}$ nos anos 1980, somente nos anos recentes parece haver sinais de uma rearticulação de um sistema financeiro habitacional capaz de ampliar a demanda de bens residenciais. A segunda metade da década de 1990 apresentou uma série de transformações que impulsionaram o interesse pelo crédito imobiliário por parte bancos e instituições financeiras em geral, sobretudo advindas da instituição do Sistema Financeiro Imobiliário, cuja criação "marca a formalização de um processo simultâneo de crescente mercantilização da política habitacional e de financeirização do mercado imobiliário, num contexto de menor intervenção estatal na questão habitacional" (BOTELHO, 2007, p. 126). Entretanto, a efetiva decolagem do SFI, argumentase, ainda depende de um declínio mais acentuado dos juros, no sentido de tornar o investimento imobiliário atrativo. Além disso, como salienta Botelho (2007, p. 126-131), a concessão de financiamentos ainda não atingiu os setores de renda mais baixa, justamente por seu fraco atrativo em termos de rentabilidade. Mesmo a classe média, que supostamente estaria mais habilitada para arcar com os custos do financiamento, teve de recorrer ao autofinanciamento como forma de baratear o acesso à moradia.

O que deve ser destacado, todavia, é que as reformas realizadas e aquelas projetadas/desejadas criam uma série de proteções destinadas a blindar os credores dos efeitos da inadimplência, como, por exemplo, a lei de alienação fiduciária, e outras que possibilitam a renegociação dos títulos de crédito em um mercado secundário (securitização) ${ }^{74}$. Essas reformas teriam como resultado uma vinculação mais estreita do mercado financeiro com o mercado imobiliário, o que corrobora com uma série de estudos recentes que

\footnotetext{
${ }^{74}$ Um documento da Câmara Brasileira da Indústria da Construção (2007, p. 16) diz o seguinte: "O aperfeiçoamento jurídico, que amplia as garantias dos financeiros (por exemplo, o patrimônio de afetação e a alienação fiduciária), e a estabilidade econômica têm permitido que alguns agentes econômicos (construtoras, incorporadoras e investidores) gerem contratos de financiamento que podem ser transformados em títulos (CRIs - Certificados de Recebíveis Imobiliários) que são negociados no mercado de capitais". Cf. também o documento "O crédito imobiliário no Brasil: caracterização e desafios" (FGV Projetos, 2007), publicado por uma equipe da Fundação Getúlio Vargas. Essas mudanças dão suporte à hipósete de Duménil e Levy (2005) a respeito do neoliberalismo como uma "segunda hegemonia das finanças", aspecto que será abordado mais adiante.
} 
vêm apontando para essa tendência ${ }^{75}$. O interesse dos bancos em fornecer crédito para o setor tende a aumentar na exata proporção em que se criem mecanismos - um "marco regulatório", termo utilizado por empresários do setor - que protejam os agentes financeiros das incertezas que recaem sobre uma linha de crédito de tão longo prazo - e, atuando nesse sentido, cita-se freqüentemente a entrada em vigor da Lei 10.931 de 2004. Uma publicação da Associação Brasileira das Entidades de Crédito Imobiliário e Poupança (ABECIP) de 2007 é explícita a respeito dessa tendência:

\begin{abstract}
A chave para o avanço do crédito imobiliário é a ampliação do mercado secundário de recebíveis imobiliários, a versão atual do mercado secundário de hipotecas. Enquanto o mercado de recebíveis não atinge seu potencial, o vigor do mercado imobiliário leva construtoras e incorporadoras a procurar o mercado de capitais, mediante a emissão de ações novas ou a venda de posições dos controladores $^{76}$.
\end{abstract}

Com efeito, essas mudanças têm ocasionado uma aceleração da concessão de crédito habitacional, ao menos no que diz respeito aos recursos mobilizados pela SBPE (Sistema Brasileiro de Poupança e Empréstimo). A dúvida que resta é saber se esse incremento no número de unidades financiadas poderá continuar até atingir setores de renda até 0 momento desamparados, como as famílias com renda de até 5 salários mínimos. Os próprios investidores e especialistas na área de negócios imobiliários são céticos, contudo, quanto à possibilidade de que sejam atendidas as famílias com esse patamar de renda sem um subsídio estatal (Revista da ABECIP, no 24 , p. 8,2007 ). Sobre as mudanças recentes que atingiram o crédito imobiliário, Botelho observa que:

[...] a desregulamentação, que foi aplicada a vários setores da economia durante a década de 1990, também atingiu o setor de financiamento habitacional. A regulação e a promoção de fontes de financiamento por parte do Estado cede lugar à provisão privada de recursos, mas essa última não tem interesse, dada a baixa rentabilidade, em atuar no mercado de renda média-baixa e baixa, que representa a grande maioria da população brasileira (BOTELHO, 2007, p. 131-2).

\footnotetext{
${ }^{75}$ Cf. Fainstein (1994); Brenner \& Theodore (2003); Hackworth (2007); para o caso do mercado imobiliário paulistano, cf. Fix (2007); Botelho (2007); Volochko (2007); Miele (2007).

${ }^{76}$ ABECIP. Revista da ABECIP. São Paulo, n² 24, p. 9, 2007.
} 
Assim, acredita-se que a expansão recente e futura nas contratações de crédito atinja mais significativamente as fatias da classe média que até então encontraram dificuldades de acesso ao crédito imobiliário em virtude dos altos juros praticados. Uma queda na taxa de juros proporcionaria a entrada no financiamento habitacional de amplos setores da classe média e os investimentos recentes de construtoras como a Rossi evidenciam um atendimento a esses setores (apartamentos na faixa de $R \$ 100$ a 150 mil com metragem inferior a $100 \mathrm{~m}^{2}$ ). Não se descarta completamente, todavia, a possibilidade de um aumento no subsídio estatal para a produção de moradias para os segmentos de renda mais baixos, sobretudo através dos recursos mobilizados a partir do Fundo de Garantia por Tempo de Serviço (FGTS), o que, no entanto, não ocorreu até então.

No que tange aos padrões de investimento no espaço que essa expansão do crédito deve gerar, é possível esperar um aumento da participação de bairros menos tradicionais, do ponto de vista da valorização imobiliária, no total dos imóveis ofertados, tendência que já se verifica, conforme os dados apresentados anteriormente.

Para concluir o capítulo: parece cada vez mais evidente 0 entrelaçamento existente entre os mercados de capitais e o mercado imobiliário. Cada vez mais, como conseqüência, o espaço se apresenta com uma opção no leque de investimentos à disposição do capital financeiro nacional e internacional. E trata-se de um investimento cada vez mais atrativo, porquanto a chamada "flexibilização", tão desejada tanto pelas instituições financeiras quanto pelas empresas do setor imobiliário, permitirá remover os entraves que tornam o investimento no ambiente construído ainda pouco atrativo, sobretudo devido à baixa liquidez desse ativo. Assim, soa como duplamente esquisita a crítica dirigida a David Harvey por Pedro Abramo trecho abaixo:

[devo expressar] meu espanto diante da posição de um geógrafo urbano da importância de Harvey que pretendia que a teoria da renda fundiária - sempre concebida como o principal elemento da coordenação intra-urbana - fosse determinada pela taxa macroeconômica de juros. Nesse caso, a configuração intra-urbana seria duplamente macrodeterminada: de um lado, pelo aspecto naturalizante da teoria da renda fundiária; do outro, pelo jogo ortodoxo do mercado monetário, ou seja, pela equilibração das 
demandas e das ofertas de moeda (e dos títulos do mercado financeiro) (ABRAMO, 2007, p. 193).

É esquisito porque, por um lado, Harvey nunca propôs que a teoria da renda fundiária fosse determinada pela taxa macroeconômica de juros. O que 0 autor diz é que a formação dos preços da terra remete a uma relação entre a renda que a propriedade oferece e a taxa de juros padrão. Ora, a renda aqui não é determinada pela taxa de juros, mas a taxa de juros e a renda da terra, juntas e em sua relação, são formadoras dos preços da terra: "the basic forces regulating the price of land and its appurtenances are the rate of interest and anticipated future rental revenues" (HARVEY, 1999, p. 367) ${ }^{77}$. Existiria, para Harvey, uma tendência de equilibração dos ganhos auferidos em renda da terra e os ganhos que podem ser obtidos no mercado financeiro com a taxa padrão de juros. Além disso, como veremos adiante, a superfície de renda da terra é mais um resultado da atividade capitalista de incorporação em sua articulação com o Estado, e não acredito que esta proposição esteja em desacordo com algumas das idéias de Harvey.

Por outro lado, Abramo parece ignorar o fato de que os mercados financeiro e de terras se encontram cada vez mais entrelaçados, de forma que movimentos na taxa de juros têm influências nítidas sobre o mercado de terras, afetando (e não determinando), por conseguinte, a orientação espacial dos investimentos na escala intra-urbana, mas sobretudo os preços das propriedades. Assim, em suas inúmeras manifestações, é cada vez mais difícil fazer uma separação que postule uma dinâmica própria à organização intraurbana, sem considerar que os processos (econômicos, sociais, políticos, etc) oriundos de escalas superiores interferem cada vez mais nessa organização. 0 tratamento da dinâmica intra-urbana que desconsidera os efeitos da organização econômica e social maior comete os mesmos equívocos da Escola de Chicago, com sua ênfase no poder de organização do centro em relação à sua hinterlândia ${ }^{78}$. Quanto ao suposto "aspecto naturalizante" da teoria da renda da terra, abordaremos no capítulo seguinte.

\footnotetext{
77 "As forças básicas que regulam o preço da terra e de seus melhoramentos são a taxa de juros e os ganhos futuros esperados na forma de renda da terra". Tradução nossa.

${ }^{78}$ Cf. Gottdiener, 1994, cap. 2.
} 


\title{
5. O significado das fronteiras urbanas na produção do espaço da metrópole: o Jardim Europa como nova centralidade de valorização imobiliária em Porto Alegre
}

\author{
Il faut donner l'apparence du nouveau au \\ repetitive, et du dynamisme à l'identique. D'ou \\ l'incroyable mixture du neo, du retro, de l'archeo, \\ dans la vie moderne.
}

Henri Lefebvre

C'est pour devenir toujours plus identique à luimême, pour se rapprocher au mieux de la monotonie immobile, que l'espace libre de la merchandise est désormais à tout instant modifié et reconstruit

Guy Debord

Uma das características nitidamente observáveis da cidade capitalista é sua incessante dinâmica de transformação espacial. Uma vez que a materialidade do espaço é veículo (meio) para a valorização do capital, podemos esperar um movimento permanente de produção e destruição do ambiente construído (destruição criativa), através do qual as configurações espaciais pretéritas cedem lugar a novos estoques que permitam a continuidade do processo de valorização. É por isso que adquire tanta força o trecho abaixo, bastante citado, de Harvey:

Capitalist development must negotiate a knife-edge between preserving the values of past commitments made at a particular place and time, or devaluing them to open up fresh room for accumulation. Capitalism perpetually strives, therefore, to create a social and physical landscape in its own image and requisite to its own needs at a particular point in time, only just as certainly to undermine, disrupt and even destroy that landscape at a later point in time. The inner contradictions of capitalism are expressed through the restless formation and re-formation of geographical landscapes. This is the 
tune to which the historical geography of capitalism must dance without cease ${ }^{79}$ (HARVEY, 2001, p. 332-3).

Caminha no mesmo sentido a seguinte afirmação de Mark Gottdiener:

[...] the essential aspect of real estate as a commodity are its low organic composition of capital and its ability to attract investment at a level in modern society which rivals the circulation of capital in the primary circuit of industrial production. Often this results in the relentless sale and resale of property, along with its conversion to alternate uses in order for the same parcel to be turned over for a profit (GOTTDIENER, 1994, p. 188) ${ }^{80}$.

Ainda para o autor,

[...] because money can always be invested with ease in the secondary circuit, such activity propels the never-ending process of property turnover and spatial restructuring, whether an area needs it or not (GOTTDIENER, 1994, p. 191)

Essa necessidade de destruir (desvalorizar) o ambiente construído herdado de forma a abrir novos caminhos para a valorização está muito presente no setor imobiliário. E aqui a desvalorização de paisagens pretéritas aparece de inúmeras formas, tendo a inovação do produto (prédios de qualidade diferenciada) uma atratividade muito grande. Isso significa que as inovações no âmbito do setor imobiliário quase sempre vêm acompanhadas da desvalorização (parcial) dos estoques imobiliários pretéritos, quer seja pela maior funcionalidade do novo produto em relação aos antigos, quer seja pela depreciação "moral" através da criação de uma nova necessidade. Sobre este último aspecto, caberia citar Lefebvre, que discorre sobre a importância da obsolescência (planejada) para a reprodução do capital:

79 "O desenvolvimento capitalista deve negociar um limite estreito entre a preservação dos valores dos compromissos pretéritos, assumidos em um lugar e em um tempo específicos, e sua desvalorização, de forma a abrir um novo campo para a acumulação. O capitalismo se esforça perpetuamente, portanto, para criar uma paisagem física e social à sua imagem e adequada às suas necessidades num momento específico do tempo, somente para tão certamente ter que miná-la, solapá-la e mesmo destruí-la num momento posterior. As contradições internas do capitalismo são expressas através da irrequieta formação e reformação das paisagens geográficas". Tradução nossa.

${ }^{80}$ As aparentes divergências que Mark Gottdiener (1994) faz questão de enfatizar, entre sua abordagem e a de Harvey parecem, em certos momentos, serem menores do que o autor pretende que sejam. Algumas das críticas que Gottdiener dirige a Harvey, sobretudo relativas ao suposto funcionalismo que transparece em sua teoria da desvalorização, parecem ser injustificadas, opinião que já havíamos manifestado acima.

81 “(...) porque o dinheiro pode sempre ser investido com facilidade no circuito secundário, tal atividade impulsiona um processo desenfreado de reciclagem do solo [property] e de reestruturação espacial, quer uma área necessite ou não". Tradução nossa. 
A obsolescência foi estudada e transformada em técnica. Os especialistas da obsolescência conhecem a esperança de vida das coisas: três anos, um banheiro; cinco anos, uma sala de estar; oito anos, um elemento do quarto de dormir; três anos, a organização de um ponto de venda local, um carro, etc. Essas médias estatísticas figuram na demografia dos objetos, em correlação com os custos de produção e os lucros. Os escritórios que organizam a produção sabem levá-las em conta para reduzir a esperança de vida, para acelerar a rotação dos produtos e do capital.

(...) A essa teoria agora bem conhecida acrescentaremos duas observações. Em primeiro lugar, a obsolescência da necessidade deveria também ser levada em conta. Aqueles que manipulam os objetos para torná-los efêmeros manipulam também as motivações, e é talvez a elas, expressão social do desejo, que eles atacam, dissolvendo-as. Para que a usura "moral" e a obsolescência das coisas trabalhem rapidamente, é preciso também que as necessidades envelheçam, que jovens necessidades as substituam. É a estratégia do desejo! (...) A obsolescência, ideologia e prática, encara o efêmero apenas como método para tornar o cotidiano rentável (LEFEBVRE, 1991, p. 91) ${ }^{82}$.

Assim, incluída nas proposições de transformação do espaço urbano levadas a cabo pelo setor imobiliário estaria a criação de novas "necessidades", a venda de signos (da modernidade, da felicidade, da exclusividade, da natureza) através dos quais se impõe uma obsolescência (fictícia, mas também real) do estoque passado ${ }^{83}$. Essa criação de necessidades é tanto mais forte à medida que, conforme anunciamos anteriormente, acreditamos que o setor imobiliário seja um dos pilares da gestão urbana neoliberal. Segundo Hackworth,

real estate investment has become quasi-autonomous because cities and capital have become increasingly reliant on it as a sector independent of the rest of the regional economy. Real estate investment of this sort is arguably the leading edge of neoliberal urbanization at the local scale ${ }^{84}$ (HACKWORTH, 2007, p. 76).

Não discutiremos mais a fundo as idéias desse autor que, ainda que digam muito sobre a realidade brasileira, possuem como pano de fundo a urbanização americana.

${ }^{82}$ Cf. também Lefebvre (2002, p. 107-8).

${ }^{83}$ Botelho (2007, p. 57), refletindo sobre o elevado preço da terra nas áreas mais valorizadas, julga ser fundamental, para a atividade imobiliária, a expansão para bairros com preço da terra menor e, para isso, acredita ser "fundamental o papel dos promotores/incorporadores imobiliários para a criação de novas necessidades, que se materializam em uma diferenciação do espaço urbano".

84 "O investimento imobiliário tornou-se quase autônomo porque as cidades e o capital se tornaram crescentemente dependentes dele como um setor independente do resto da economia regional. $\mathrm{O}$ investimento imobiliário desta natureza, pode-se argumentar, é o carro-chefe da urbanização neoliberal na escala local". Tradução nossa. 
O foco deste capítulo consiste, então, em tentar compreender a inovação/diferenciação no contexto da produção residencial de forma a explicar, em parte, a dinâmica de localização residencial na metrópole gaúcha, enfocando as transformações que estão ocorrendo nos arredores do shopping center Iguatemi e as estratégias que estão por trás dessas transformações (ver Mapa 10 para uma representação da área de estudo). Subjacente a uma reflexão desta natureza deve estar presente um entendimento da estruturação intra-urbana cujos debates envolvem diferentes tradições/orientações teóricometodológicas. A perspectiva que orienta a presente pesquisa rejeita a suposição neoclássica/neoliberal de uma "soberania do consumidor" que direcionaria o crescimento/organização do espaço urbano. Não se trata de negar o papel da demanda e do consumidor final na estruturação do espaço urbano, mas de reconhecer as determinações que advêm da produção capitalista e que limitam o poder de decisão do consumidor final. Compartilhamos, então, das críticas dirigidas às teorias neoclássicas do uso do solo urbano por David Harvey (1980), Keith Bassett \& John Short (1980), Mark Gottdiener (1994), Neil Smith (1996) e Pedro Abramo (2007), embora sejam críticas realizadas a partir de perspectivas diferenciadas. 


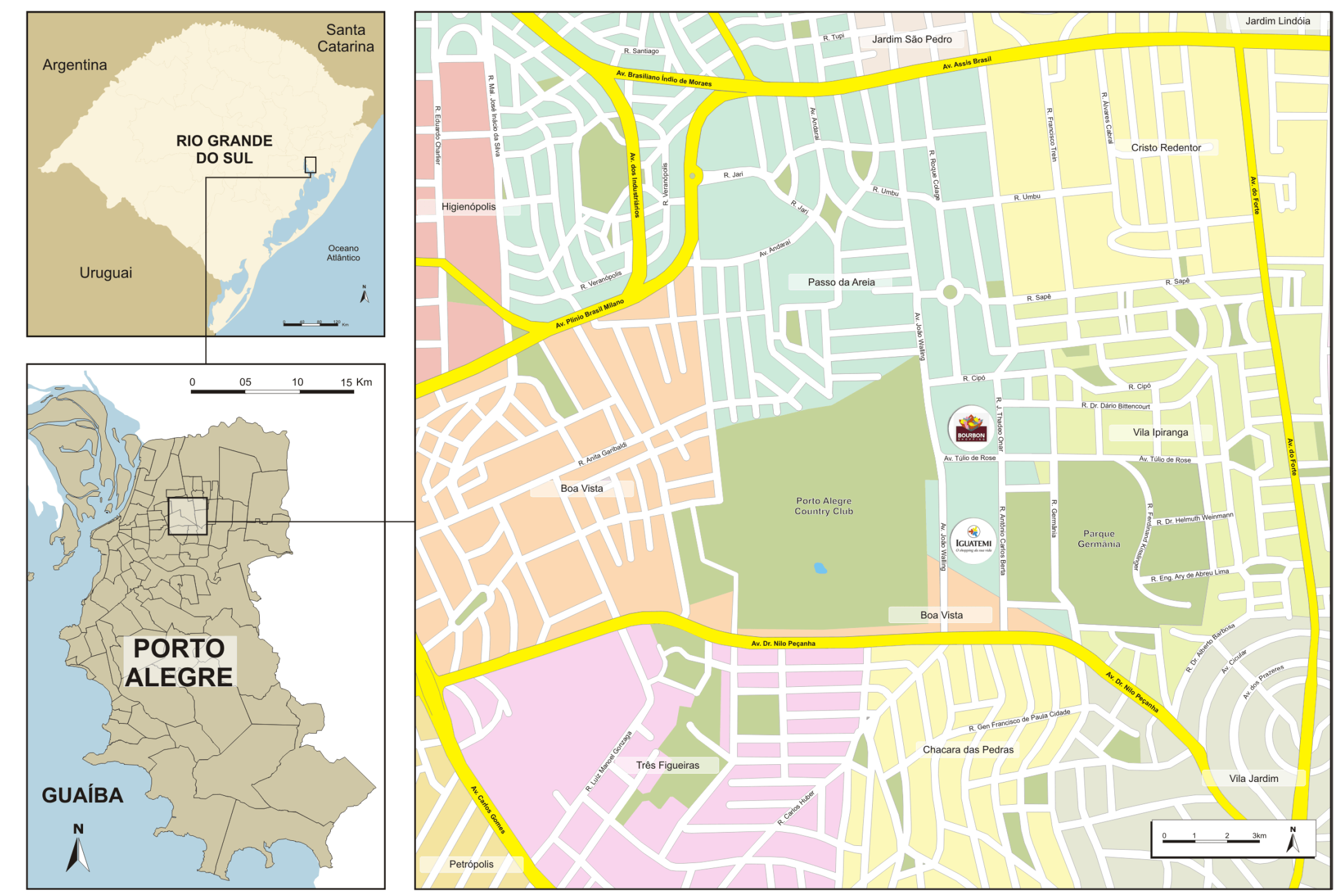

Mapa 10 - O Parque Germânia e a área do entorno dos shoppings Iguatemi e Bourbon. 
A teoria do rent gap, então, fornece os elementos para compreender, ao menos em parte, a dinâmica imobiliária na medida em que ela indica uma oportunidade de investimento como uma condição sine qua non para que os interesses econômicos se direcionem para determinada área do tecido urbano, ainda que a teoria seja insuficiente para explicar, em sua totalidade, a forma de organização intra-urbana do espaço. Nesse sentido, acreditamos que Abramo (2007) se equivoca ao atribuir uma suposta naturalização à teoria da renda da terra. A teoria da renda da terra não explica, de antemão, a forma que a configuração intra-urbana adquirirá e, portanto, não naturaliza a distribuição das classes sociais, ao menos na sua versão dialética (e, de fato, a crítica de Abramo faz muito mais sentido se direcionada exclusivamente à teoria da renda defendida pela tradição neoclássica thüneniana, ainda que o autor pareça extrapolar sua crítica de forma a atingir toda e qualquer teoria da renda do solo). O que a teoria da renda da terra consegue explicar é que, num contexto de impossibilidade de distribuição equitativa da infra-estrutura urbana sobre todo o tecido metropolitano - ou mesmo supondo a distribuição efetiva de infra-estrutura sobre todo o tecido -, a constituição de centralidades, aliada à existência da propriedade privada da terra, permitirá, em certas localidades, a obtenção de uma renda superior à média e, sendo a renda a base da formação dos preços do solo, a variação dos preços seguirá a formação/destruição/recriação dessas centralidades. Essas centralidades, no entanto, são formadas de maneira complexa, a partir de um conjunto de investimentos (e desinvestimentos) públicos e privados que variam ao longo do tempo e, por esta razão, todas as propriedades estão sujeitas às "vicissitudes" da proximidade relativa já mencionadas no segundo capítulo. Não se trata, então, de uma relação de distância absoluta com o CBD (Central Business District) ou com o Centro histórico, em cujo caso estaríamos raciocinando somente a partir de uma noção absoluta (geométrica e euclidiana) de espaço. Além disso, as mudanças na configuração espacial intra-urbana estão profundamente entrelaçadas com mudanças ocorridas em escalas mais amplas, as quais devemos levar em conta ${ }^{85}$. Devemos, então, estar aptos a explicar como ocorre a formação de novas centralidades no espaço urbano,

\footnotetext{
${ }^{85}$ É com esse ponto de vista que pusemos em foco, no final do capítulo anterior, as novas
} condições de financiamento imobiliário. 
das quais a superfície diferencial formada pelas rendas é uma conseqüência. Nesse sentido, estamos de acordo com os argumentos de Mark Gottdiener no fragmento abaixo:

Clearly theories of rent and location provide only limited ways of understanding the articulation of capital and space. It is more fruitful to study the role of the secondary circuit and its array of institutions and individuals involved in the turnover of real estate for profit than it is to analyze ground rent within an urban context using nineteenth-century concepts derived from agricultural production ${ }^{86}$ (GOTTDIENER, 1994, p. 193).

Isto dito, acreditamos que a noção de convenção urbana, defendida por Abramo (2007), parece, à primeira vista, ser bastante pertinente, contanto que não aceitemos sua abordagem keynesiana da formação dos preços por convenção ${ }^{87}$. Se o rent gap fornece um indicativo do potencial de investimento em determinado local e, portanto, da possibilidade de formação de uma nova centralidade, a constituição de representações, no plano cognitivo, fortalece as perspectivas de captura efetiva desse potencial (rent gap) na medida em que se forma um consenso quanto ao potencial de rentabilidade do investimento em determinada área, o que serve de sinalização ao investidor individual e às famílias que desejam habitar ${ }^{88}$. Mas seria preciso dar mais ênfase ao papel da publicidade na orientação do processo, e abandonar o termo "convenção", pois ele pode levar a crer que se trata de um consenso ao qual todos os atores do mercado residencial urbano chegaram.

De maneira geral, costuma-se pôr em evidência, quando se trata de entender a dinâmica da inovação no âmbito da produção residencial, o fato de que, devido à durabilidade do bem residencial, os estoques passados entram em concorrência com os novos estoques residenciais produzidos. Dessa forma,

\footnotetext{
86 "É visível que as teorias da renda da terra e da localização proporcionam apenas limitadas possibilidades de compreender a articulação entre capital e espaço. Seria mais frutífero estudar o papel do circuito secundário e o conjunto de instituições e indivíduos envolvidos no giro imobiliário em busca do lucro do que analisar a renda do solo em um contexto urbano utilizando conceitos do século XIX derivados da produção agrícola". Tradução nossa.

87 "(...) a convenção urbana seria uma opinião convencional, uma crença compartilhada pelos atores urbanos sobre a localização residencial (virtual) dos diferentes tipos de família. Enquanto referência de localização, ela vai tornar-se o elemento de coordenação espacial dos atores que permite a configuração das externalidades de vizinhança" (ABRAMO, 2007, p. 127).

${ }^{88}$ Abramo define a convenção urbana como uma "crença referente ao tipo de família que, supostamente, vai instalar-se numa determinada localização (externalidade de vizinhança) segundo as inovações espaciais (diferenciações do bem moradia) propostas pelos capitalistas" (2007, p. 287).
} 
e sobretudo no caso de cidades cuja população tende para a estabilização, o mercado imobiliário costuma criar mecanismos para depreciar os estoques passados através da venda de produtos mais modernos, mais equipados, ou simplesmente através de signos que veiculem certos valores. Essa diferenciação permite que, em certa medida, os capitalistas possam vender suas mercadorias a um preço de monopólio, ou quase isso, realizando sobrelucros.

Pode-se dizer, então, que a inovação-diferenciação no âmbito da produção imobiliária é fundamental à reprodução do capital no setor (ABRAMO, 2007). Ela é ainda mais importante no que estamos tratando como "fronteiras urbanas", caracterizadas por uma proposta de alteração da localização espacial das classes sociais no contexto da metrópole. Isso porque, para atrair famílias situadas no segmento de renda médio-alto para áreas que não eram caracterizadas por uma ocupação desse tipo de família, o mercado imobiliário se vê obrigado a criar atrativos diferenciados, seja veiculando signos do bemestar e da felicidade, seja oferecendo equipamentos diferenciados ${ }^{89}$. É isso que procuraremos identificar, daqui em diante, no caso do Jardim Europa, o "bairro" que está sendo construído pela Goldsztein S.A.

$O$ trajeto aqui realizado parte de um resgate histórico do desenvolvimento dos bairros adjacentes ao shopping Iguatemi, fundamentando-se, para tanto, principalmente em trabalhos anteriores e reportagens em jornais locais que tratem do assunto. Esse resgate permitirá corroborar com a hipótese, aqui aventada, de que o processo de valorização do entorno do shopping Iguatemi atingiu primeiramente os bairros situados ao Sul e Oeste desse empreedimento, ao passo que os anos recentes (e provavelmente futuros) assistiram à valorização mais intensa dos bairros a Leste e Norte do shopping Iguatemi. Deve-se ter em vista que consideramos, aqui, esse complexo comercial como um importante - mas não único, como se verificará mais adiante - indutor da valorização dessa área e por isso merecerá atenção especial nessa primeira parte do capítulo. Em seguida o trabalho deverá dar um enfoque maior ao empreendimento-bairro Jardim Europa,

\footnotetext{
${ }^{89}$ Uma novidade que, nos anos recentes, caiu nas graças das práticas do setor imobiliário residencial foram os lofts, que consistem em apartamentos com mezaninos e pé-direito elevado. Esse tipo de apartamento surgiu, na verdade, nos EUA como uma forma de aproveitamento dos espaços de estruturas industriais obsoletas.
} 
proposto pela parceria já mencionada. Nessa etapa, será necessário um estudo mais minucioso dos acordos e parcerias estabelecidos entre a construtora Goldsztein e a Prefeitura municipal na construção e gestão da infraestrutura instalada na área; dos pormenores envolvidos na permuta $e$ parcelamento do terreno sobre o qual se estabeleceu o empreendimento, pois a área de estudo configurava-se como um extenso vazio urbano até 2006; e das possíveis alterações que deverão advir. Tudo isso deverá ser balizado pela tentativa de compreender as estratégias de negócios que estão por trás de um empreendimento desse porte e que, de modo geral, orientam os negócios capitalistas no âmbito da produção do espaço urbano. Nesse trecho, pretendemos utilizar-nos de estudos anteriores, documentos oficiais, entrevistas, reportagens de jornais, anúncios publicitários e dados variados.

\subsection{O shopping Iguatemi como propulsor inicial da valorização}

O shopping Center Iguatemi (e o shopping Bourbon Country, adjacente, inaugurado em 2001) situa-se, hoje, na confluência de cinco bairros oficiais, já mencionados acima: Passo da Areia, Vila Ipiranga, Vila Jardim, Chácara das Pedras e Boa Vista. Além disso, dois bairros podem ser considerados, pela sua proximidade, como áreas sob forte influência desses dois empreendimentos: Três Figueiras e Cristo Redentor. A área compreendida por esses bairros oficiais, que até 1950 era muito pouco urbanizada, começa a ser incorporada com mais vigor à região mais urbanizada a partir dos anos 1960, sobretudo quando da instalação de dois colégios importantes no atual bairro Três Figueiras (o colégio Anchieta e o colégio Farroupilha). A instalação desses dois colégios já serviu de atrativo para a expansão do eixo valorizado que se estendia, então, até o bairro Petrópolis. Essa ocupação de alta renda caracterizou-se pelo predomínio de casas residenciais a partir do loteamento das antigas chácaras situadas no que hoje corresponde aos bairros Três Figueiras e Chácara das Pedras. As restrições impostas pela regulação urbanística permitiram que esses dois bairros permanecessem com 0 predomínio de casas. As outras áreas, principalmente os bairros Passo da Areia, Cristo Redentor e Vila Ipiranga, permanecem apresentando um uso 
residencial de classe média e média-baixa, panorama que só começou a se modificar nos anos recentes.

Não são muitos os estudos disponíveis que abordam os efeitos, do ponto de vista da valorização imobiliária, da instalação do shopping Iguatemi em 1982 na área onde antes havia chácaras, tambos de leite em solo de difícil drenagem e algumas casas esparsas. Dois estudos anteriores, ainda que utilizando metodologias diferentes da aqui empregada, deverão nos auxiliar a avaliar algumas das transformações ao longo dos anos subseqüentes à instalação do mencionado empreendimento comercial: o estudo de Clarice Maraschin (1993) e o de Rozana Araújo (2005).

O estudo realizado por Clarice Maraschin (1993) observou transformações importantes sobrevindas à instalação do Iguatemi, em 1982. Em todas as zonas que circundam o empreendimento houve incremento da renda média domiciliar no período que compreende 1974 e 1986, quando da realização de duas pesquisas de renda domiciliar, e valorização dos terrenos. Os bairros de Três Figueiras, Chácara das Pedras e Boa Vista, que já vinham recebendo moradores de estratos de renda mais elevados, se consolidaram como bairros "nobres" da cidade. Já os bairros situados na área oposta com relação ao empreendimento, embora tenham apresentado os mesmos efeitos, por longo tempo após o surgimento do shopping continuaram se configurando como de ocupação por estratos de renda médio (Passo da Areia, Vila Ipiranga e Cristo Redentor) e médio-baixo (Vila Jardim). A pesquisa de rendimento médio dos responsáveis pelo domicílio de 2000, abaixo para os bairros em estudo, ainda exibe essa ruptura nitidamente. 
Tabela 4 - Rendimento médio domiciliar em 2000.

\begin{tabular}{l|c}
\hline Bairro & $\begin{array}{c}\text { Rendimento médio dos responsáveis } \\
\text { pelo domicílio em SM }\end{array}$ \\
\hline Três Figueiras & 37,00 \\
Boa Vista & 25,76 \\
Chácara das Pedras & 20,68 \\
Cristo Redentor & 10,61 \\
Passo da Areia & 9,96 \\
Vila Ipiranga & 8,99 \\
Vila Jardim & 5,30 \\
\hline
\end{tabular}

Fonte: IBGE

O trabalho de Maraschin ainda aponta outros elementos importantes. A autora observa (MARASCHIN, 1993, p. 100) que a pavimentação completa da avenida Nilo Peçanha, no trecho que liga a av. Carlos Gomes com o shopping, hoje importante corredor de circulação, ocorreu justamente na época de finalização do empreendimento comercial. $O$ trabalho não indica em que medida - e nem parece ser seu objetivo indicá-lo - a consecução dessa obra teve influência do anúncio do investimento pelo grupo Iguatemi, mas, como sabemos, o poder público costuma ser bastante prestativo para garantir o êxito dos grandes investimentos no ambiente construído e no comércio de grande escala e a realização dessa obra certamente foi um elemento a mais na tendência à valorização imobiliária da área. De maneira complementar, houve uma extensão dos serviços de transporte público para o local, com novas linhas de ônibus e lotação chegando ao shopping ou áreas vizinhas.

Além disso, Maraschin (1993, p. 103-15) assinala uma transformação no padrão médio construtivo dos edifícios surgidos após a instalação do Iguatemi. A autora verifica um incremento dos lançamentos imobiliários de padrão alto e médio-alto, com a construção de torres e condomínios horizontais em várias áreas próximas ao Iguatemi (ver Figura 2) a partir do parcelamento de vazios urbanos. O único vazio urbano de maior extensão que não foi aproveitado nesse período (entre 1980 e 1990) foi a Chácara Silva Bier, área que deu origem ao loteamento recente para o mega-empreendimento Jardim Europa. A autora conclui que "o shopping desempenhou o papel de criar condições para a 
expansão mais extrema daquele setor [da cidade], abrindo caminho para uma ocupação pelos altos estratos de renda" (1993, p. 123). As grandes incorporadoras, então, e ainda segundo Maraschin, afluíram para área de forma a aproveitar o sobrelucro proporcionado pelos custos menores dos terrenos.

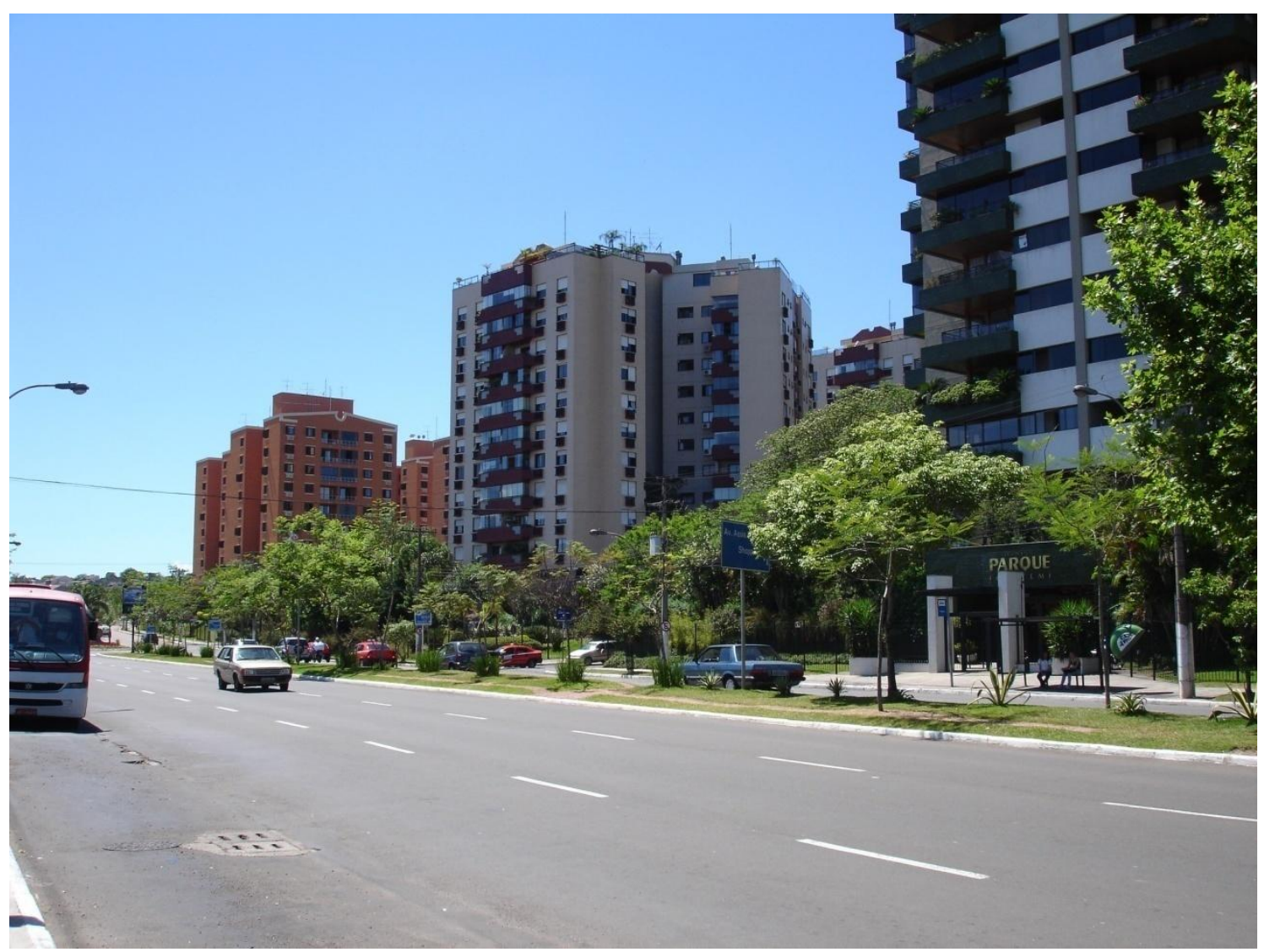

Figura 2 - Edifícios situados em frente ao shopping Iguatemi construídos durante a década de 1990. Foto do autor.

A dissertação de Araújo (2005), utilizando metodologia semelhante, mas restrita aos bairros Boa Vista, Três Figueiras e Chácara das Pedras, confirma a importância do empreendimento na valorização dos imóveis situados nesses bairros, bem como aumento do tráfego e da atividade comercial na avenida Nilo Peçanha, principal ponto de acesso ao Iguatemi para o público-alvo do empreendimento, proveniente dos bairros de renda mais elevada. A crescente oferta de imóveis com padrão construtivo alto e o aumento da renda média desses bairros durante a década de 1990 foram os principais indicadores utilizados pela autora para atingir essa conclusão. Mas a autora não aborda os bairros que acreditamos estar, agora, no centro dos interesses imobiliários. 
A valorização que se deu a partir de 2000 parece ter atingido com mais força aqueles bairros cujo estoque residencial ainda não tinha se transformado por completo, como a análise dos dados acima ajudou a comprovar. Mas o coroamento desse processo de longa data certamente foi o anúncio do empreendimento Jardim Europa, do qual trataremos daqui em diante.

\subsection{O empreendimento Jardim Europa: natureza do projeto}

O empreendimento Jardim Europa surge da proposta da empresa Goldsztein S.A. de lotear um grande vazio urbano, com área total de 406.562 $\mathrm{m}^{2}$, localizado no bairro Vila Ipiranga. O projeto inicial previa, nessa área, a abertura e prolongamento das vias, a urbanização do Parque Alemanha - um parque já previsto pela Lei Municipal 6688, de outubro de 1990 - e a construção de 37 edifícios residenciais, muitos dos quais ainda não tiveram sua construção iniciada ${ }^{90}$. O total estimado do investimento é de $\mathrm{R} \$ 73$ milhões, em uma estimativa feita em 2001. O parque situar-se-ia no centro do lote parcelado, ao redor do qual estariam posicionadas as torres residenciais. No parque, foram instaladas canchas de esportes, locais de lazer e contemplação e lagos numa área total de $150.809 \mathrm{~m}^{2}$. As Figuras 3, 4 e 5, obtidas em Junho de 2008 registram os primeiros edifícios em vias de finalização e uma parte do Parque Germânia. A Figura 6 ilustra a localização do empreendimento conforme os destaques colocados por um anúncio publicitário da empresa e a Figura 7, por fim, reproduz o projeto da empresa de acordo com a intenção original, exposta no Relatório de Impacto Ambiental do empreendimento (PROFIL, 2001). Por fim, conforme o relatório mencionado, a empresa responsável compromete-se a desenvolver projetos para contemplar as exigências das Secretarias Municipais, como "bacias de amortecimento, preservação de espécies imunes ao corte e ameaçadas de extinção, criação de corredores para a manutenção da fauna, etc" (PROFIL, 2001, p. 5). Um desses projetos incluiu, por exemplo, a requalificação da Praça Conselheiro Antônio Prado, no bairro Chácara das Pedras. A incorporadora renovou o equipamento

\footnotetext{
${ }^{90}$ Informações obtidas no Relatório de Impacto Ambiental do empreendimento.
} 
público da praça, instalando bancos, lixeiras, um playground, duas quadras esportivas e renovando as calçadas e escadas.

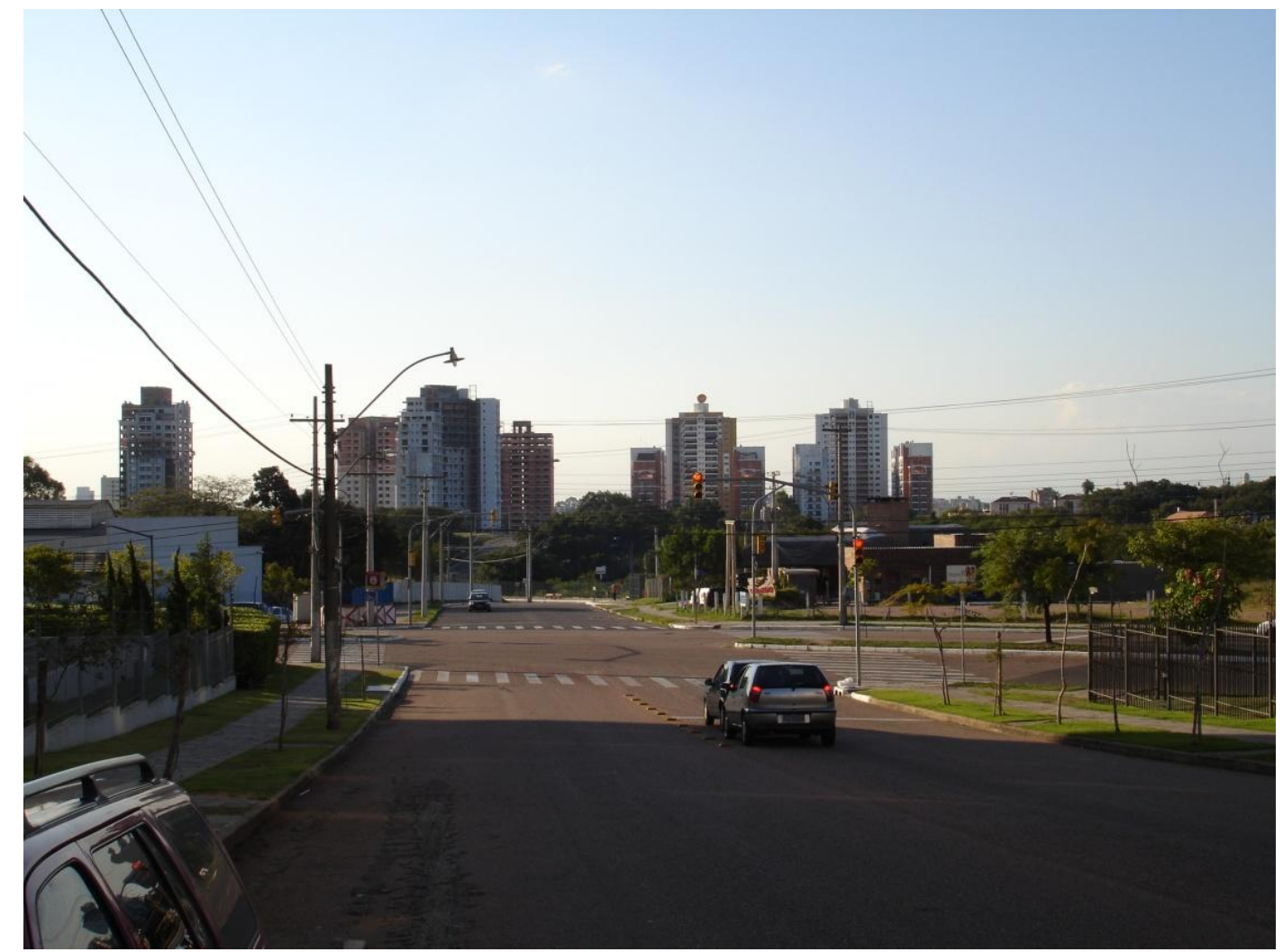

Figura 3 - Primeiros edifícios do empreendimento em vias de finalização, vistos a partir da Rua Tremembé (junho de 2008). Foto do autor. 


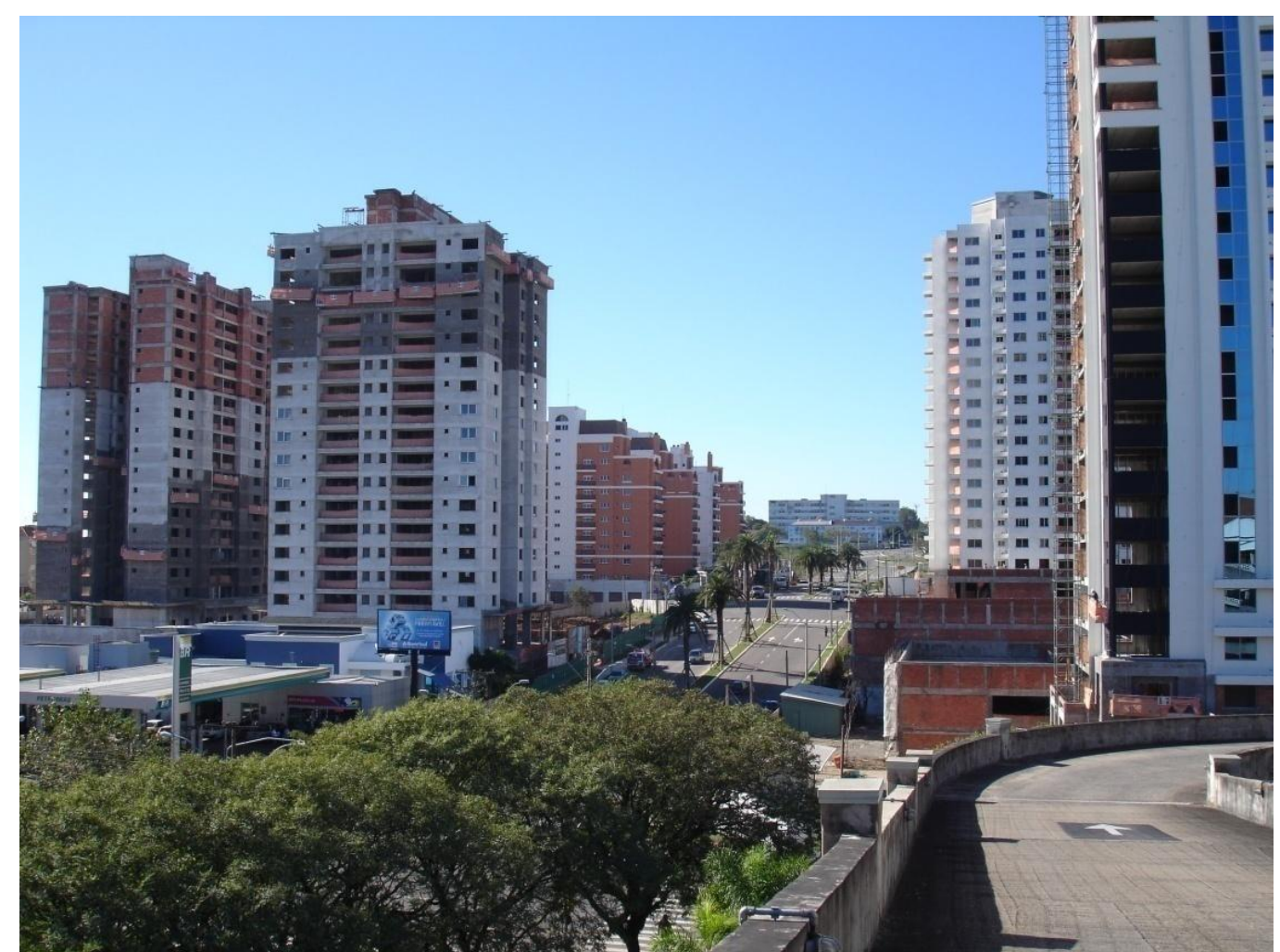

Figura 4 - Vista do Jardim Europa a partir do estacionamento do Shopping Iguatemi (Junho de 2008). Foto do autor.

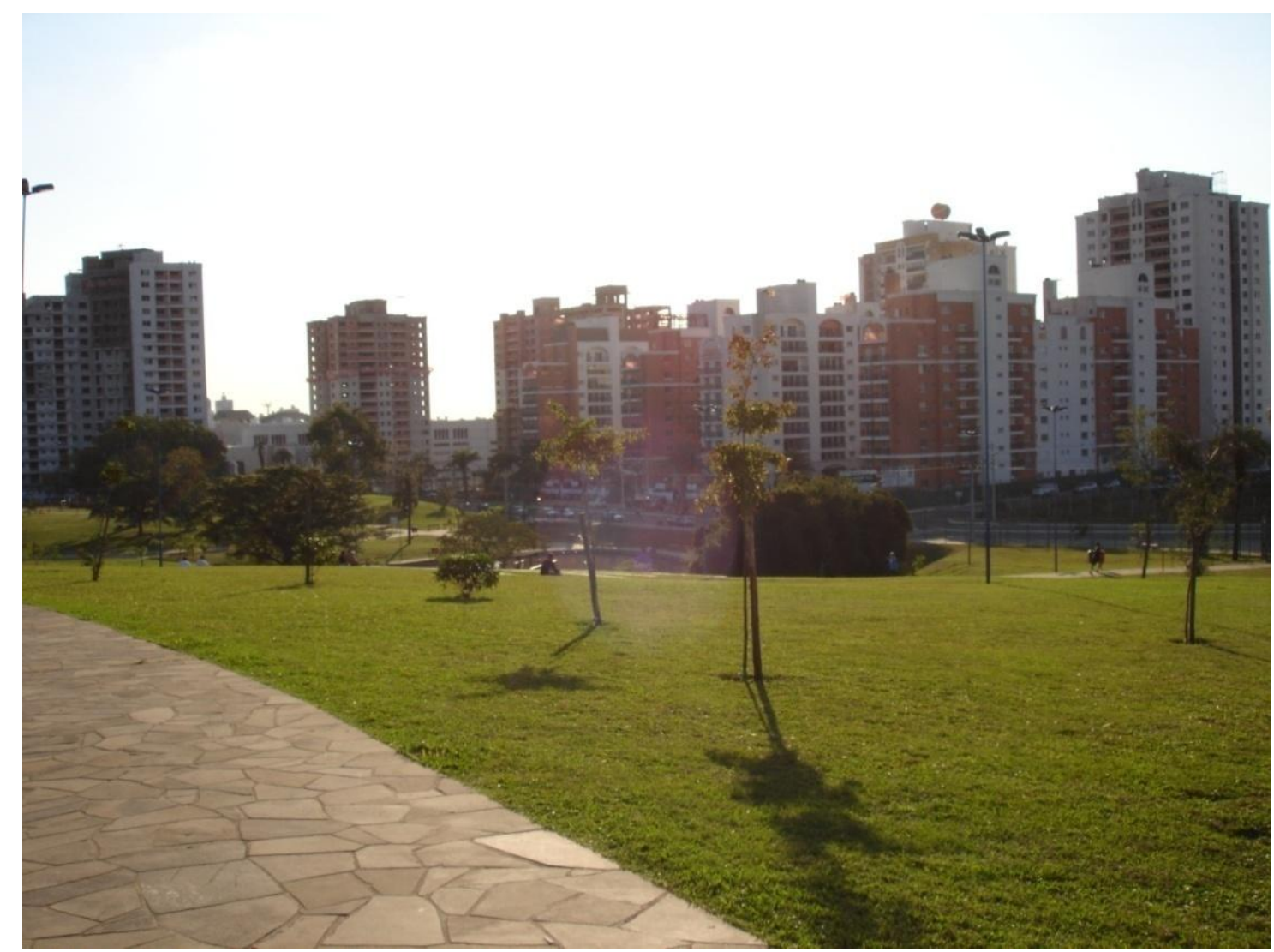

Figura 5 - Vista parcial do parque e dos primeiros edifícios em processo de finalização (Junho de 2008). Foto do autor. 


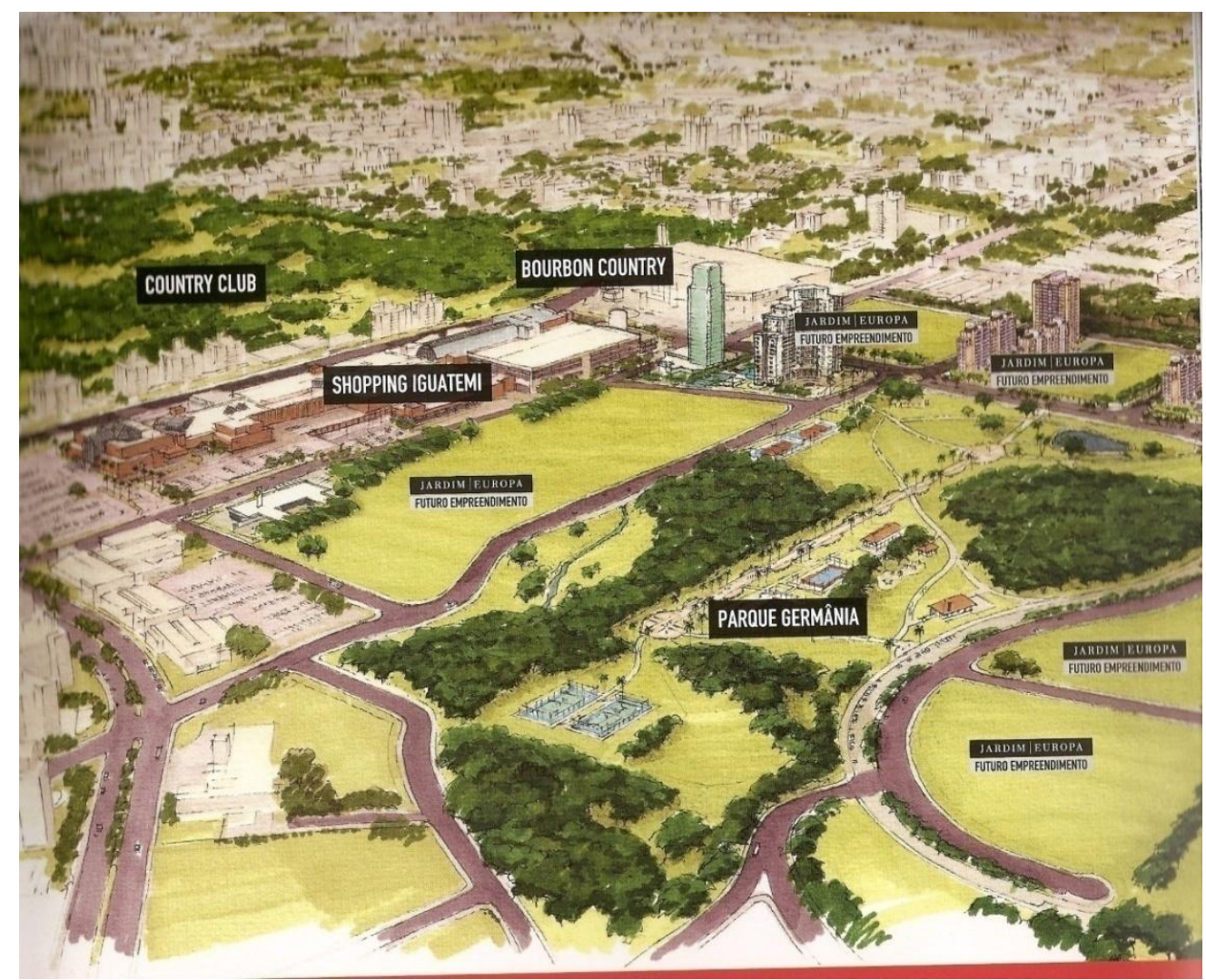

Figura 6 - Anúncio publicitário da Goldsztein sobre o Jardim Europa. Fonte: Folheto de publicidade. 


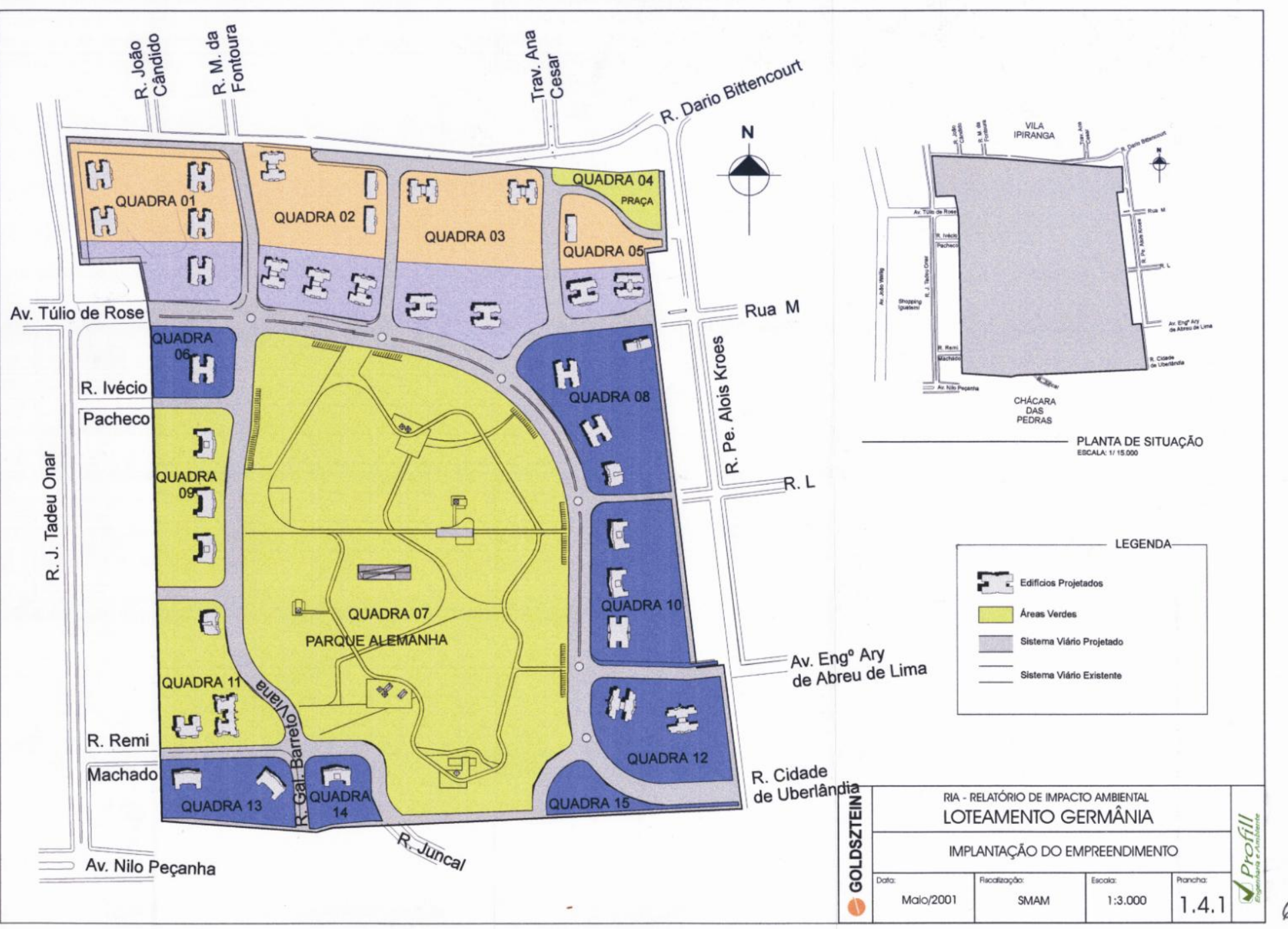

Figura 7 - Projeto original do loteamento Germânia, apresentado em 2001. Fonte: PROFIL (2001). 
O empreendimento é justificado, pelo empreendedor, como um projeto que

\begin{abstract}
foi concebido levando em conta o interesse do Município de contemplar a Zona Norte com um parque de grandes dimensões e que, além de manter o equilíbrio natural da região, possibilite o acesso da população de mais de dez bairros a uma área verde verdadeiramente ímpar (PROFIL, 2001, p. 8)
\end{abstract}

Embora a justificativa tenha sua relevância, pois de fato um parque público de grandes dimensões está ausente na região, veremos, em seguida, como o parque cumpre um papel fundamental na reprodução do espaço como mercadoria, figurando como núcleo privilegiado das estratégias de valorização imobiliária orientadas para o local estudado. Ainda segundo a justificativa do empreendedor,

a implementação deste loteamento e do seu parque será a possibilidade de utilização, pela comunidade, de um "pulmão" que hoje existe e que ninguém acessa (PROFIL, op.cit, p. 8)

Ainda que o trecho não explicite a qual "comunidade" pretende referir-se, existem evidências suficientes para supor que a utilização do parque, por suas próprias características, deverá ser bem maior entre os habitantes de maior poder aquisitivo, o que tende a reproduzir, no uso do espaço público, o processo de segregação sócio-espacial que caracteriza a estrutura residencial da metrópole. É importante lembrar que boa parte do bairro Vila Ipiranga, onde está o empreendimento, era caracterizado por uma ocupação de renda média e baixa, configuração que aos poucos vai se modificando. Voltaremos a discutir esse aspecto mais adiante.

A iniciativa privada deverá arcar, portanto, com os custos de urbanização (vias e equipamentos do parque) da área. Como essa mesma justificativa faz questão de salientar, a área do Parque supera em $82.061 \mathrm{~m}^{2} \mathrm{o}$ total previsto para Áreas de destinação pública e, segundo o Relatório de Impacto Ambiental do loteamento, esse excedente foi "objeto de permuta" com o município, não explicitando a natureza da permuta ${ }^{91}$. Contudo, toda essa área de destinação pública, que totalizou $224.358 \mathrm{~m}^{2}$ no projeto, foi destinada

\footnotetext{
${ }^{91} \mathrm{~A}$ entrevista que realizamos também não nos esclareceu a respeito desta permuta.
} 
ao Parque e às vias, não havendo, por exemplo, área destinada a uma escola ou a qualquer outro equipamento público.

No que tange à negociação com a Condor S.A., proprietária do terreno que deu origem ao loteamento, soubemos, através de entrevista realizada na Goldzstein, que, em troca dos investimentos em infra-estrutura, a empresa obteve quatro terrenos do loteamento. O restante dos terrenos ainda pertencem à Condor e deverão ser fruto de negociação futura, provavelmente através da repartição dos ganhos do produto final.

A construção do parque, a extensão da malha viária que liga o Centro ao leste da cidade, a eliminação de um vazio urbano e o desenvolvimento urbano em geral são as justificativas que com mais freqüência aparecem para sustentar o argumento da necessidade de aprovação do empreendimento no Relatório de Impacto Ambiental. O que devemos abordar, contudo, é a importância da fronteira e, no interior desta, do parque como estratégia de valorização.

5.3. O Parque Germânia como estratégia de valorização: a "autenticidade" como criação da publicidade

Um aspecto inicial que deve ser observado no empreendimento é a redobrada atenção dirigida pela empresa Goldsztein ao Parque Jardim Europa. Com efeito, não só a empresa arcou sozinha com todos os custos de urbanização do parque, como também, em um acordo com a Prefeitura Municipal, comprometeu-se a administrar o Parque por 20 anos. O Parque de fato destaca-se entre os parques do município, por contar com uma infraestrutura e um paisagismo muito bem elaborados, área de preservação ambiental, segurança assegurada pelo próprio empreendimento e, como os anúncios publicitários fazem questão de colocar em relevo, pelo fato de se tratar do primeiro parque cercado do Município. Mas o interesse da Goldsztein pelo parque é também - talvez principalmente - seu interesse próprio. A valorização da área é tão intensa que permite a Goldsztein realizar todas as obras de urbanização e ainda obter uma margem de retorno significativa. E o 
atrativo simbólico exercido pelo Parque proporciona o eixo ao redor do qual os anúncios publicitários giram.

E aqui é que devemos dedicar um pouco mais de atenção, pois a efetivação final de uma fronteira urbana, da maneira como estamos entendendo aqui, traduz-se em uma alteração efetiva na espacialização das classes sociais no interior da metrópole. O que torna o investimento em áreas de "fronteira" de alguma maneira mais complexo é o fato de que, uma vez que a proposta é atrair camadas de alta renda cuja associação simbólica imediata se dá com os bairros "tradicionais" e "nobres" da metrópole - no caso de Porto Alegre, os bairros Moinhos de Vento e Bela Vista, por exemplo - é preciso criar um imaginário, repleto de ideologia, que confira status e bom gosto à opção de habitar um novo bairro. Nesse sentido, a obsolescência das necessidades, de que Henri Lefebvre fala no trecho citado acima, constitui um mecanismo fundamental ao que Mark Gottdiener (1994) definou como a interminável "reciclagem" (turnover) dos usos do solo na metrópole contemporânea.

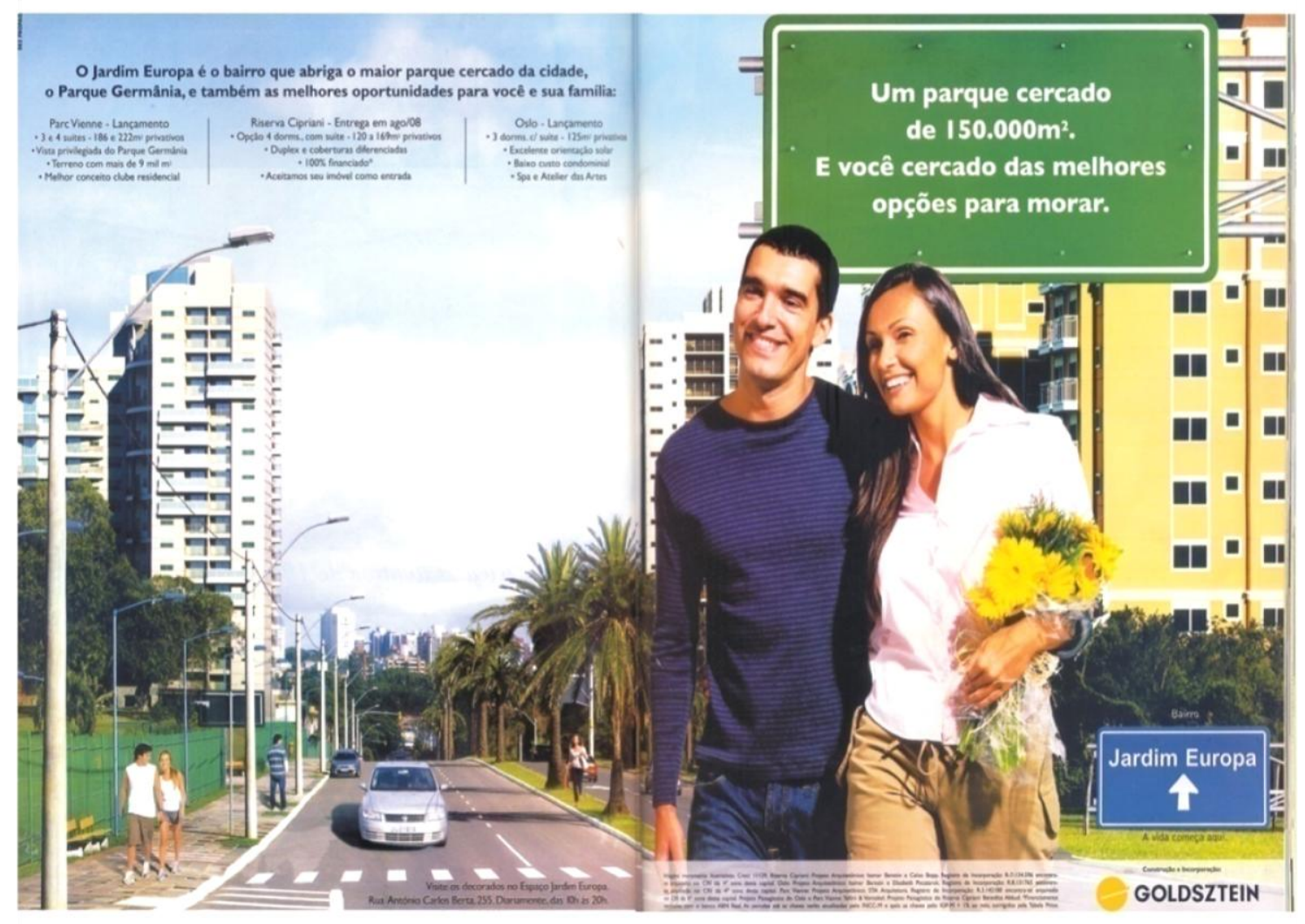

Figura 8 - Anúncio publicitário do Jardim Europa (1). Fonte: Folheto publicitário. 


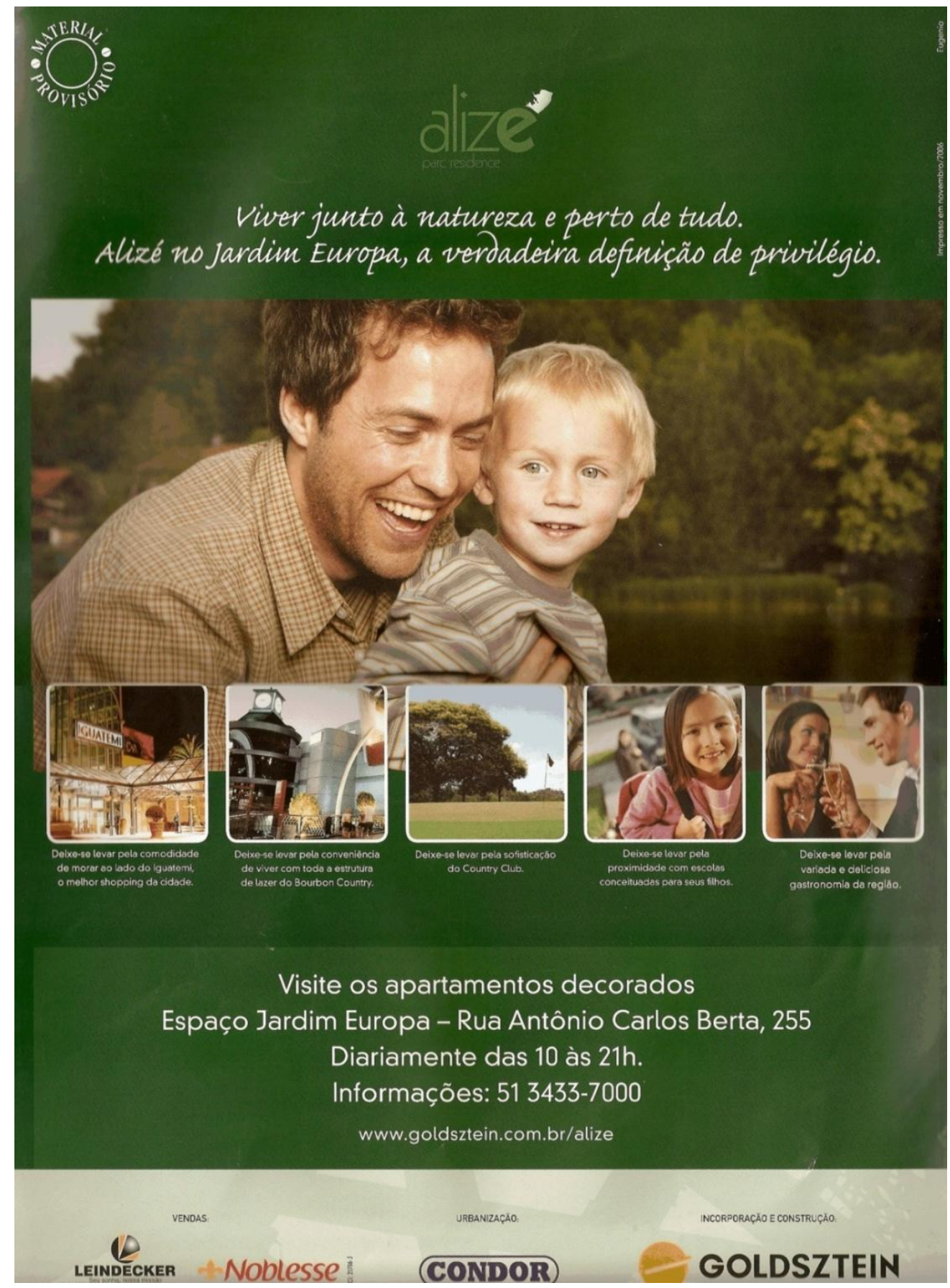

Figura 9 - Anúncio publicitário do Jardim Europa (2). Fonte: Encarte publicitário no Jornal Zero Hora (11/05/2008).

O investimento em publicidade, portanto, proporciona uma aura de distinção ao comprador da área selecionada. E, no caso aqui estudado, a conjunção do parque e dos shopping centers de alto padrão, distantes uma quadra um do outro, parece ser o fator mais relevante a contribuir para a valorização da área. Em entrevistas realizadas na Goldsztein, tanto com corretores quanto com a Gerente de Projetos da empresa, o parque e os empreendimentos comerciais são evocados como atrativos fundamentais do 
empreendimento $^{92}$. E os anúncios publicitários dos empreendimentos evocam incessantemente esses aspectos. Na Figura 8, por exemplo, o anúncio publicitário destaca a presença do maior parque cercado da cidade. A Figura 9, por sua vez, coloca em evidência os benefícios de "viver junto à natureza". A natureza aqui é reduzida a simples "signo" que, como salienta Henri Lefebvre (2003, p. 27), é cada vez mais produzido em massa para ser vendido. Assim, para Lefebvre

There is a continuous reference to nature in advertising, whether it be for food or textile products, housing or vacations. To provide meaning and content (illusory), the re-presentation of nature is accompanied by the full range of "floating signifiers" employed by rethoric. What no longer has a meaning is given one through the mediation of a fetishistic world of nature. Undiscoverable, fugitive, ravaged, the residue of urbanization and industrialization, nature can be found everywhere, from feminility to the most mundane object. Parks and open spaces, the last word in good intentions and bad urban representation, are simply a poor substitute for nature, the degraded simulacrum of the open space characteristic of encounters, games, parks, gardens and public squares. This space, which has been neutralized by a degrading form of democratization, has as its symbol the square. The urbanist passively obeys the pressures of number and least cost; the functionality he thinks he has created is reduced to an absence of "real" functions, to a function of passive observation ${ }^{93}$ (LEFEBVRE, 2003, p. 27)

No plano das estratégias de valorização empreendidas pelo mercado imobiliário, por um lado, o parque e a área preservada permitem a obtenção de um preço de monopólio de venda final ao consumidor ao agregar ao produto uma singularidade derivada de uma representação, uma espécie de capital simbólico que contribui para a realização da mais-valia e a obtenção de um

92 Serpa (2007) explicita alguns dos aspectos que fazem do parque urbano, hoje, um instrumento fundamental à valorização do solo.

93 "Há uma contínua referência à natureza na publicidade, seja para a venda de alimentos, produtos têxteis, habitação ou férias. Para conferir significado e conteúdo (ilusório), a representação da natureza é acompanhada por um amplo espectro de "significantes flutuantes" empregados pela retórica. Não encontrável, fugitiva, destruída, o resíduo da urbanização e da industrialização, a natureza pode ser encontrada em todo lugar, desde a feminilidade até os objetos mais mundanos. Parques e espaços abertos, a última palavra em boas intenções e má representação urbana, são simplesmente um pobre sucedâneo para a natureza, o simulacro degradado do espaço aberto característico dos encontros, jogos, parques, jardins e praças públicas. Esse espaço, que foi neutralizado por uma forma degradante de democratização, tem como símbolo a praça. $O$ urbanista obedece passivamente as imposições do número e do menor custo; a funcionalidade que ele acredita ter criado é reduzida a uma ausência de funções "reais", a uma função de observação passiva". Tradução nossa. Cf. também Lefebvre (1970, p. 162-3). 
lucro excedente na economia atual ${ }^{94}$. É por essa razão que a construção e preservação do parque são de fundamental importância para a realização lucrativa do investimento. Por outro lado, no plano do uso, o parque revela-se como negação - ou como um simulacro degradado, nas palavras de Lefebvre do encontro como possibilidade do espaço público, ao reproduzir a segregação sócio-espacial que marca a organização espacial da cidade contemporânea.

Isso nos conduz à reflexão de que o Jardim Europa se insere num plano em que o urbano reproduz-se através da cotidianidade, entendida como conjunto de constrangimentos e impossibilidades à apropriação do espaço e da vida entendida como autêntica. Os espaços residenciais propostos pelo empreendimento articulam-se aos de (consumo do) lazer e de (lazer pelo) consumo e concorrem ativamente para a reprodução das relações sociais de produção através da cotidianidade. A construção da individualidade na sociedade do consumo dirigido passa sempre mais pelas relações fetichistas de mercado e pelos signos que atravessam as mercadorias para conferir uma aura sagrada a elas. O sujeito realiza-se e constrói-se, como individualidade, através do consumo e este, como onipresente, afasta o sujeito do mundo real da política, da cultura, etc, e da reflexão sobre estas esferas para além da esfera privada. O espaço neutralizado que é proposto nos anúncios do empreendimento mescla representações que fazem referência ao urbano com aquelas que negam o urbano, tentando oferecer a idéia de que o habitante está em contato próximo com a "natureza" e, sobretudo, afastado das mazelas da urbanização capitalista. Trata-se, então, de um espaço depurado, afastado, segregado, neutralizado, característico da "utopia" que sustentou a suburbanização nos países anglo-saxões (FISHMAN, 1996). Mas aqui, face à especificidade da condição social brasileira, o Jardim Europa, como propositor de um modo de vida "suburbano" baseado no consumo ostensivo, no uso do automóvel e no afastamento da cidade real, optou não pelas casas amplas com jardins e sem cercas, mas pelas torres verticais modernas com segurança e vigilância digital, os "enclaves fortificados" de que nos fala Teresa Pires Caldeira. O distanciamento do urbano real, então, se realiza pelo consumo

${ }^{94}$ Sobre a agregação de um capital simbólico como forma de obtenção de um preço de monopólio, cf. Harvey $(1989 ; 2001)$. Sobre o papel do imaginário da natureza no contexto da suburbanização na Inglaterra e nos EUA, cf. Fishman (1996). 
dirigido, pela venda de signos veiculados pela publicidade e pela segregação residencial e de uso do espaço público ${ }^{95}$. Como observa Valquíria Padilha, em seu interessante estudo sobre o shopping center como local de sociabilidade na sociedade contemporânea,

[...] o consumo tem [...] seu índice máximo de segurança na máxima exclusão do mundo real, social e histórico, ou seja, o consumo é um jogo de signos que, para existir no cotidiano das pessoas, sublima o mundo real por meio da publicidade e da televisão (PADILHA, 2006, p. 102).

Nesse sentido, a centralidade dos shopping centers na proposta de vida "suburbana" 96 vai para além da simples funcionalidade de poder adquirir os bens necessários à vida num local próximo à residência. Os shoppings exercem uma funcionalidade também simbólica e constituem um

[...] espaço de construção de identidade. Um espaço onde há o imperativo de ser percebido: as pessoas freqüentam shopping centers também para serem vistas e percebidas pelos outros, e assim, travam uma relação entre "ser eu" e "ser percebido" (PADILHA, 2006, p. 134).

Desta maneira o espaço como um todo se realiza como valor de troca, impondo o ritmo acelerado da circulação do capital e dos valores e ideologias mercantis para o conjunto da sociedade. A cidade como encontro, a cidade como diferença, fica sufocada sob os imperativos homogeneizantes da troca mercantil e, por conseguinte, da cotidianidade. E a cidade como obra inexiste a não ser no simulacro da obra, na produção da diferença pelo estetismo da mercadoria (e aqui é relevante o fato de que os primeiros empreendimentos evoquem estilos arquitetônicos diferentes, como o condomínio Parc Vienne, que reproduz elementos da arquitetura vienense, o Karpathos, que traz aspectos do estilo arquitetônico das ilhas gregas, e o Cipriani, inspirado na arquitetura da costa mediterrânea da Itália, todos de localização próxima, em

\footnotetext{
${ }^{95}$ Para Fishman (1996, p. 24), a utopia burguesa que deu suporte à construção dos subúrbios baseia-se no desejo de um "refúgio não apenas de elementos ameaçadores na cidade, mas também de elementos discordantes na própria sociedade burguesa". Tradução nossa. Original: (...) a refuge not only from threatening elements in the city buy also from discordant elements in bourgeois society itself".

${ }^{96}$ Não queremos aqui entrar no mérito da conceituação do "suburbano". O que importa é que não é necessário estar para além dos limites institucionais de um município para que um bairro seja caracterizado como suburbano. Como diz Fishman, a suburbanização envolve principalmente uma separação mais radical entre o espaço de trabalho e o espaço de lazer, bem como um afastamento das mazelas da cidade central.
} 
uma espécie de pastiche pós-moderno). Para Henri Lefebvre, a sociedade atual, de consumo dirigido, vive constantemente a imitar e reproduzir "les oeuvres des sociétés antérieures (pré-capitalistes), les livrant à la consommation massive" (LEFEBVRE, 2002, p. 27) ${ }^{97}$. Do ponto de vista do espaço como meio de sociabilidade, trata-se do que Lefebvre denominou "seuil inférieur de la sociabilité, au dela duquel la survie serait impossible parce que toute vie sociale aurait disparu" (LEFEBVRE, 2000a, p. 377) ${ }^{98}$. O imperativo do ver e do ser visto, traço distintivo de um espaço abstrato e visual, reduz a sociabilidade à proximidade do grau zero. E aqui fica evidente novamente como a mobilização do campo simbólico e cultural constituem momentos da valorização do capital e da valorização do espaço pelo capital, discussão já levada a cabo no primeiro capítulo. A contradição que se estabelece nesse processo, e que se revela no plano dos discursos publicitários, é aquela que aponta para uma homogeneização que se efetiva através do apelo à singularidade e à autenticidade (Figura 10) ${ }^{99}$. A diferença, aqui reduzida ao puro estetismo, é sinônimo da universalidade homogeneizante do capital, ou poderíamos dizer que se situa no âmbito das diferenças induzidas, em contraposição às diferenças produzidas (LEFEBVRE, 2000a, p. 429-30). Para Lefebvre, haveria em tudo isso um predomínio crescente das representações. "Le 'monde des signes', afirma Lefebvre,

[...] ce n'est pas seulement l'espace occupé par des signes et images (par des objects-signes et des signes-objects). C'est l'espace où l'Ego n'est plus en rapport avec sa nature, avec une matière, même pas avec la 'choséité' des choses (marchandises) mais avec les choses doublées de leurs signes et supplantés (suppléées) par ceux-ci (LEFEBVRE, 2000a, p. 358) ${ }^{100}$

97 “(...) as obras das sociedades anteriores (pré-capitalistas), entregando-as ao consumo de massa". Tradução nossa.

98 “(...) limiar mínimo da sociabilidade, além do qual a sobrevivência seria impossível porque toda vida social haveria desaparecido". Tradução nossa.

${ }^{99}$ Henri Lefebvre diz, ainda, que "(...) l'espace architectural et urbanistique dans la modernité tend vers (...) [un] caractere homogène: lieu de la confusion et de la fusion entre le géométrique et le visuel, il engendre un malaise physique. Tout se ressemble" (2000, p. 231). Tradução: "(...) o espaço arquitetural e urbanístico na modernidade tende para (...) [um] caráter homogêneo: lugar da confusão e da fusão entre o geométrico e o visual, ele engendra um mal-estar físico. Tudo se parece". Cf. também Lefebvre (2000 p. 257). Um artigo fundamental no que concerne às relações entre a abstração do capital financeiro e as formas arquitetônicas atuais é o de Jameson (2006), intitulado "O tijolo e o balão: arquitetura, idealismo e especulação imobiliária".

100 "O mundo dos signos não é somente o espaço ocupado pelos signos e imagens (por objetos-signos e signos-objetos). É o espaço onde o Ego não está mais em relação com sua natureza, com uma matéria, nem mesmo com a 'coisidade' das coisas (mercadorias), mas 
Para José de Souza Martins, a incorporação de signos do moderno em um cotidiano ainda profundamente permeado por relações tradicionais seria 0 componente fundamental da modernidade latino-americana. "A modernidade [na América Latina]", diz o autor, "se apresenta [...] como a máscara para ser vista. Está mais no âmbito do ser visto do que no do viver" (MARTINS, 2008, p. 33).

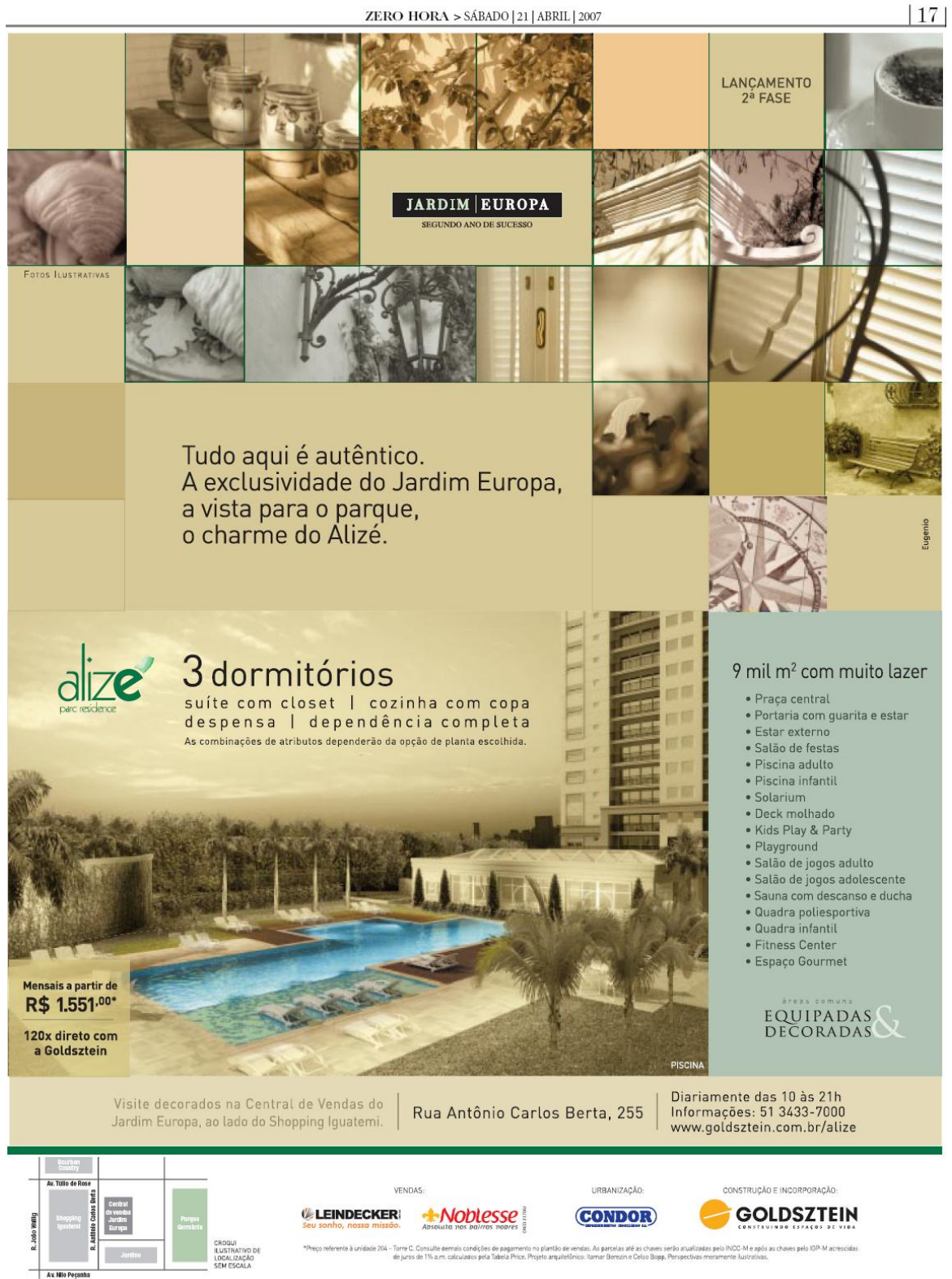

Figura 10 - Anúncio publicitário do Jardim Europa. Fonte: Zero Hora (21/04/2007). Ainda que seja difícil encontrar uma diferença essencial entre o empreendimento da Goldsztein e todos os outros que são lançados o tempo todo na cidade, o apelo à autenticidade e à exclusividade são recorrentes no plano dos discursos publicitários.

com as coisas duplicadas pelos seus signos e suplantadas (preenchidas) por estes". Tradução nossa. 
À imprensa local não passou despercebido o empreendimento imobiliário, como era de se esperar, dada a escala do projeto. O jornal Zero Hora, por exemplo, proporcionou considerável cobertura não apenas ao surgimento do Parque, o que se esperaria, em se tratando de um novo espaço público, mas aderiu ao discurso ideológico publicitário que apresenta 0 Loteamento Germânia como novo bairro (Figura 11) ${ }^{101}$. Quanto ao Parque, são constantes as menções, no jornal local, à segurança e ao cuidado na sua manutenção. E, de fato, o parque Germânia proporcionou segurança, principalmente como fruto de uma parceria entre o Poder público (que aceitou o cercamento de um parque e, além disso, está acertando a transferência de um Batalhão da Polícia Militar para o interior do mesmo ${ }^{102}$, em prédio a ser construído pela Goldsztein) e da iniciativa privada, que instalou um sistema de segurança próprio. Não é necessário destacar, novamente, o papel que o discurso da segurança cumpre nas estratégias de valorização, de maneira que a segurança do Parque torna-se essencial ao sucesso do empreendimento ${ }^{103}$.

Para finalizar este item, é preciso ser bem claro quanto ao que foi discutido, para evitar mal-entendidos: afirmamos aqui que a venda de signos desempenha um papel destacado na venda do Jardim Europa como fronteira de valorização, e que a publicidade maciça é parte integrante das estratégias de venda. Mas é preciso não cometer nenhuma extrapolação: o que está à venda, acima de tudo, são valores de uso, aos quais a publicidade contribui para conferir um preço de monopólio. O que está a venda juntamente com um imóvel é, acima de tudo, uma distância, e é por isso que Lefebvre (2000a, p. 391) afirma que muitas vezes os signos cumprem um papel compensatório em relação a um espaço-distância menos privilegiado.

\footnotetext{
${ }^{101}$ Cf. Zero Hora (01/03/2005, p. 19; 24/03/2006, p. 46; 19/04/2006, p. 31).

102 Cf. Zero Hora, 24 de março de 2006. O Batalhão sairia do atual bairro Bom Jesus, onde as necessidades de policiamento são inegáveis, devido à presença de grupos associados ao tráfico de drogas no local.

${ }^{103}$ Não se trata, aqui, de negar a importância da segurança para que se possa usufruir dos parques, mas houve uma preocupação adicional da empresa para proporcionar segurança ao parque, sobretudo com parceria com a Prefeitura.
} 


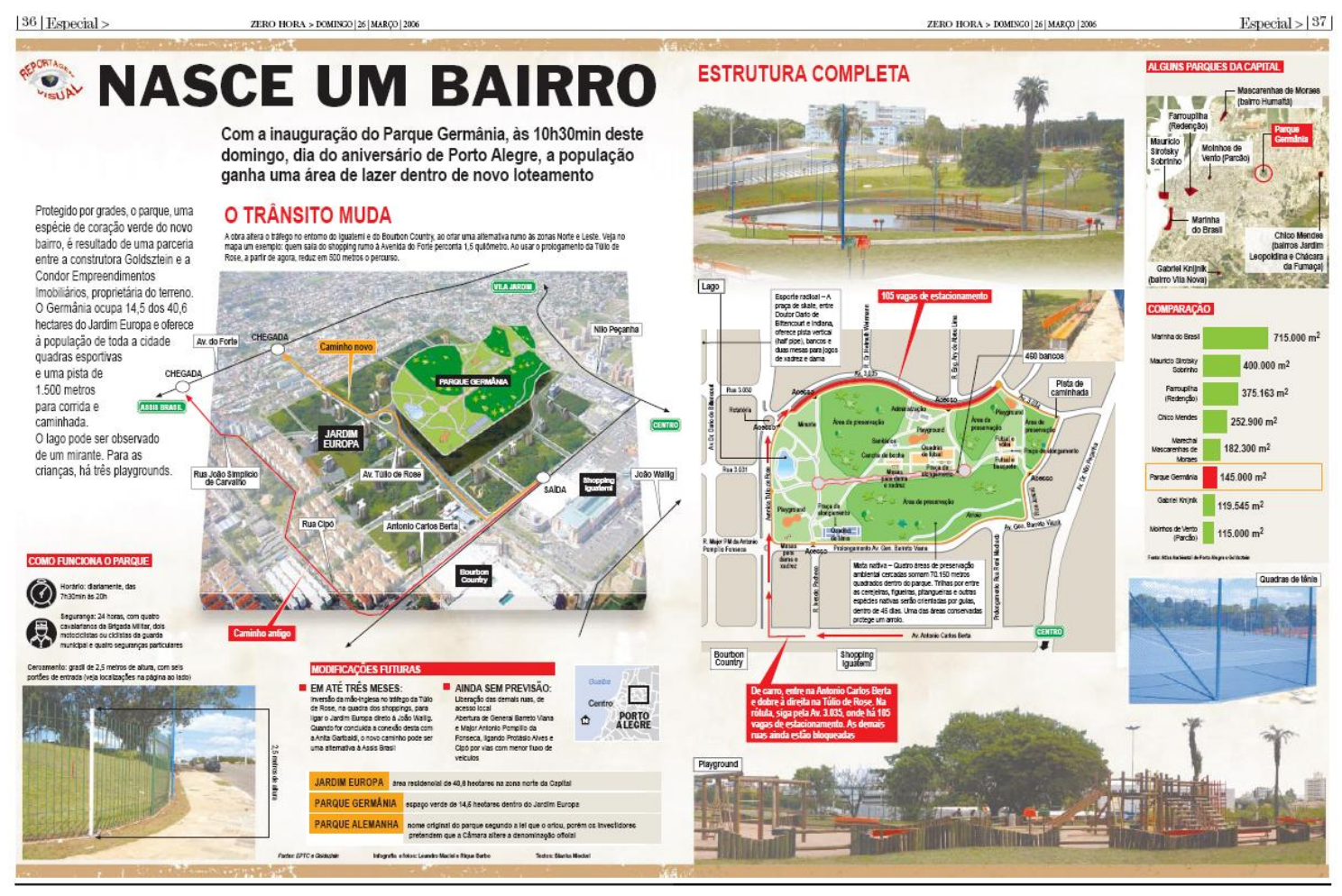

Figura 11 - Reportagem do jornal Zero Hora sobre a inauguração do Parque Germânia. Fonte: Zero Hora (26/03/2006). A reportagem reproduz a intenção da empresa de oferecer o Jardim Europa como um "novo bairro", planejado e em harmonia com a natureza, portanto em desencontro com o restante da cidade.

5.4. Risco e sobrelucro no investimento em fronteiras urbanas

Devemos abordar um outro aspecto importante da constituição do Jardim Europa como fronteira de valorização. Já havíamos mencionado um pouco acima que o que entendemos como fronteira urbana envolve, na maior parte das vezes, uma proposta de transformação na distribuição espacial das classes sociais. Esse é o caso do Jardim Europa, que avança o eixo valorizado da cidade mais para Leste. Como é presumível, tal proposta inclui grau considerável de risco. Quando, ao longo do trabalho, destacamos o papel mais fundamental que a atividade imobiliária possui em determinar as direções de valorização, o que rompe com a idéia de soberania do consumidor nas teorias neoclássicas de uso do solo urbano, não pretendemos, também, autonomizar a oferta diante da demanda. Enfim, o que queremos salientar é que não são poucos os empreendimentos imobiliários que não proporcionam o resultado esperado do ponto de vista da remuneração, da velocidade de vendas ou 
mesmo da possibilidade de venda. Assim, se é nas fronteiras urbanas que é possível a apropriação de um sobrelucro, em função de uma renda potencial, também é nelas que o risco cumpre um papel mais relevante. Todavia, o que devemos também saber a respeito do que Queiroz Ribeiro (1997) denominou "a moderna incorporação imobiliária" é seu esforço, fundamentado em pesquisas e cálculos cada vez mais minuciosos e precisos, para minimizar riscos. Se, por ser uma fronteira, a área inevitavelmente apresenta mais riscos ${ }^{104}$, os procedimentos adotados pelas empresas (e que envolvem o uso maciço de publicidade) reduzem esses riscos. Nesse sentido, é importante mencionar um trecho de entrevista realizada com Lilian Maya Rodrigues (Gerente de projetos da Goldsztein) e Carla Piccoli (Coordenadora de Projetos da mesma empresa). Perguntada sobre os fatores que mais pesam sobre a viabilidade de um empreendimento, Lilian Rodrigues afirma que

a primeira coisa quando se avalia o local é ter certeza e isso quando a gente não tem, se faz uma pesquisa de mercado, seja qualitativa, quantitativa, para saber exatamente qual produto para aquele local específico. Mas são vários os fatores que influenciam na viabilidade econômica. A primeira delas, sem dúvida, é o valor do terreno, o preço que o proprietário põe em cima daquele terreno, o custo de construção, o valor de comercialização, e também como tu vai distribuir financeiramente tanto a venda quanto a despesa. Então, a distribuição financeira, e aí contabilizam-se todas as coisas. Claro que existem coisas fixas, que independe. Depende do valor que o negócio gera: comissões, verbas de marketing, verbas de manutenção, tudo isso é contado. Mas hoje, assim, o impacto maior é o preço do terreno, o valor de construção, as taxas de administração adotadas e a distribuição financeira. Nós trabalhamos hoje com uma meta dentro da empresa, e claro que cada empresa estabelece um resultado final, ou seja, um valor líquido de resultado sobre aquele negócio. Tem empresas que, de repente, viabilizam negócios que talvez outras não porque os valores, os percentuais de resultado que uma trabalha são diferentes da outra.

\section{E, ao complementar o que Lilian disse, Carla Piccoli diz que}

em geral a gente [a Goldsztein] nunca entra "achando", a gente entra sabendo. A gente tem pesquisa e formas de calcular custos e retorno muito alinhadas, porque são anos de experiência e anos avaliando o negócio. Então, em geral quando se escolhe um terreno, uma localização e se lança um produto, é sabendo. Às vezes a surpresa é [que] vendeu muito rápido ou vendeu um pouco mais devagar que o esperado, mas nunca tem uma surpresa muito grande, porque tem

${ }^{104} \mathrm{E}$, aqui, a título de exemplo, cabe mencionar o sucesso abaixo do esperado que uma fronteira urbana como o Panamby, em São Paulo, representou para o fundo imobiliário proprietário das áreas de incorporação, como mostra a pesquisa de Volochko (2007). 
muitos anos de experiência em pesquisa. Então, complementando, não se fecha a compra de um terreno se não se tem a certeza efetiva do negócio em si, se a viabilidade é positiva ou não ${ }^{105}$.

Nesse sentido, longe de ser um "tiro no escuro", a fronteira urbana avança com toda a precaução econômica da qual pode dispor hoje o capital incorporador, o que garante o retorno lucrativo dos investimentos. Nesse sentido, as empresas possuem uma sensibilidade muito aguda a respeito dos espaços pelos quais podem avançar e obter sobrelucros. Neil Smith expressa magistralmente esse aspecto, fazendo uso de uma metáfora de avanço militar:

\begin{abstract}
The economic geography of gentrification is not random; developers do not just plunge into the heart of slum opportunity, but tend to take it piece by piece. Rugged pioneersmanship is tempered by financial caution. Developers have a vivid block-by-block sense of where the frontier lies. They move in from the outskirts, building 'a few strategically outposts of luxury', as Henwood has put it. They "pioneer" first on the gold coast between safe neighborhoods on one side where property values are high and the disinvested slums on the other where opportunity is higher. Successive beachheads and defensible borders are estabilished on the frontier. In this way economic geography charts the strategy of urban pioneering (SMITH, 1996, p. 23) ${ }^{106}$.
\end{abstract}

Assim, na busca de sobrelucros, o risco quase sempre é diluído por essa sensibilidade mais aguda atingida pelas incorporadoras no seu avanço sobre áreas menos valorizadas. As grandes incorporadoras possuem estratégias elaboradas para avançar sobre áreas pouco valorizadas e transformá-las de acordo com seus interesses. É esse avanço por "estratégicos postos avançados de riqueza", também, que explica o fato de que a expansão imobiliária adquire uma direção predominante no espaço urbano, como observou Flávio Villaça (2001) para um conjunto de metrópoles do Brasil. Em outro trecho da entrevista com a Goldsztein, Lilian Rodrigues, ao comentar o sucesso dos primeiros lançamentos do empreendimento, deixa claro o

\footnotetext{
${ }^{105}$ Entrevista concedida em 12/08/2008.

106 "A geografia econômica da gentrificação não é aleatória; as incorporadoras não se atiram, simplesmente, na oportunidade de obter lucros em áreas desvalorizadas, mas tendem a tomá-las aos poucos. O pioneirismo destemido é temperado com precaução financeira. Os incorporadores possuem uma sensibilidade vívida, de quarteirão em quarteirão, de onde se situa a fronteira. Eles penetram pelas bordas, construindo "uns poucos e estratégicos postos avançados de luxuosidade", como colocou Henwood. Eles desbravam em primeiro lugar a Costa do Ouro [Gold Coast] situada entre os bairros seguros onde os valores do solo são mais elevados, de um lado, e as periferias pouco investidas onde as oportunidades [de ganho] são maiores, do outro. Sucessivos enclaves e linhas defensivas são estabelecidas na fronteira. Desta maneira, a geografia econômica traça a estratégia do pioneirismo urbano". Tradução nossa.
} 
significado da fronteira como situada entre a "Gold Coast" dos bairros de valorização consolidada e os de bairros que sofrem desinvestimento:

Nós fizemos o primeiro lançamento... nós começamos a construção das obras de infra-estrutura do Jardim Europa, que nós conseguimos ter a licença de instalação do loteamento, isso foi em janeiro de 2005. Janeiro ou fevereiro de 2005. E ficou pronto em fevereiro de 2006. Em um ano a gente fez a parte de infra-estrutura, e aí durante o ano de 2005 a gente já trabalhou nos primeiros empreendimentos, nos primeiros projetos. Nosso primeiro lançamento foi em abril de 2005, que foi o Cypriani Nova Arquitetura. Logo em seguida teve 0 Kharpatos e, realmente, foi um sucesso o primeiro empreendimento, e o segundo empreendimento, vizinho ao Cypriani Nova Arquitetura, que é o Reserva Cypriani, ele estava programado para um ano depois. Ele aconteceu 45 dias depois. Então foi bem surpreendente. $E$ ali, o que que se entendia? Que era uma área muito nobre, uma área que hoje está muito desenvolvida e nobre dentro da cidade, junto à Chácara das Pedras, à área do Iguatemi, que hoje é um shopping de um padrão alto na cidade, mas era uma área de divisor de águas, porque ali para trás é a Vila Ipiranga, a Avenida do Forte [áreas menos valorizadas], enfim, mas a gente acreditou e entendeu que dava para caracterizar aquele empreendimento todo como alto padrão, como médio e alto e puxar para cima e expandir essa área da cidade (Grifo nosso).

Ao "puxar para cima" e "expandir" (em termos de valor), a Goldsztein realiza o sobrelucro, pois se apropria da renda potencial da área ${ }^{107}$. É esse o sentido do "divisor de águas" de que fala a entrevistada. O processo de expansão do eixo valorizado, para o qual o Jardim Europa contribui, tende a seguir a mesma direção porque existe uma estrutura comum, uma espécie de "economia de aglomeração", proporcionada pela proximidade dos bairros de alta renda, representada pelas inúmeras instalações relacionadas a consumo, serviços e empregos das quais as classes de mais alta renda desejam estar próximas e as quais não podem ser produzidas pelo capital individual, ainda que a tendência à centralização do capital em grandes corporações pode, de certa forma, produzir certas "externalidades", como no caso do Alphaville e outros condomínios fechados ${ }^{108}$. Mas é a localização (acessibilidade), lembra-

\footnotetext{
${ }^{107}$ Essa apropriação da renda potencial, que resulta no lucro de incorporação, depende muito do preço pago pelo terreno. O que a Goldsztein fez foi estabelecer uma parceria com a Condor, proprietária do terreno, pela qual a Condor permutaria três terrenos com a Goldsztein em troca dos custos de instalação de infra-estrutura no loteamento. O restante dos terrenos segue pertencendo à Condor e, imagina-se, parte do produto final vendido pela Goldsztein deverá servir para remunerar a Condor. Esta é uma solução importante que a Goldsztein utilizou para dissolver o preço do terreno e conseguir o sobrelucro.

108 Cf. Villaça (2001). Abramo (2007) parece desconsiderar a "inércia do espaço" quando diz que as "externalidades de vizinhança" podem ser reproduzidas em outro local. Voltaremos a discutir esse assunto nas considerações finais.
} 
nos sempre Villaça (2001), o valor de uso fundamental do espaço, e ser "fora de mão", como se diz comumente - e na expressão é feita uma referência implícita a alguma centralidade - desvaloriza um bairro.

A entrevista realizada na Capa também põe em relevo o potencial de valorização do local mas, segundo Vanderlei Tamiosso, a empresa está tendo cuidado com possíveis "empecilhos" para a construção na região.

\begin{abstract}
A Capa/Rodobens sempre busca oportunidades de negócios onde se possa obter preço competitivo para os clientes, assim sempre olhamos para esta região com muita atenção, víamos esta região como o novo eldorado do mercado imobiliário de Porto Alegre. Porém, com a implantação do Cone aéreo (legislação internacional de segurança aérea em função do aeroporto), deve-se ter muito cuidado, pois o potencial construtivo de um terreno pode ser afetado (altura) por esta legislação ${ }^{109}$.
\end{abstract}

A possibilidade de alteração da legislação de uso do solo em um bairro com relativa proximidade do aeroporto é encarada, portanto, pela Capa, com um possível entrave à efetivação do "novo eldorado" do mercado imobiliário de Porto Alegre.

5.5. A expansão da malha viária do Corredor de Centralidade Nilo Peçanha-Anita

É imprescindível, também, que comentemos a respeito da discussão com associações de bairro no que tange aos efeitos do empreendimento sobre suas áreas vizinhas, o que, como se verá, pode aparecer como uma digressão em relação ao que vínhamos discutindo, mas que se revela importante. Essas discussões com os moradores se realizaram, na época, através dos Fóruns Regionais de Planejamento, instâncias regionais de participação que permitem a discussão com a comunidade quando da realização de um empreendimento gerador de grande impacto na vizinhança. Enquanto que não houve, na época, qualquer objeção ao empreendimento em si, a sua efetivação, ao eliminar um vazio urbano, trouxe à tona a intenção, já prevista pelo Plano Diretor do município, de ampliação do eixo viário da Anita Garibaldi - no que o

${ }^{109}$ Entrevista concedida em 14/09/2008. 
Plano Diretor denominou Corredor de Centralidade Anita-Nilo Peçanha. Os moradores do bairro Vila Ipiranga e do bairro Jardim Itu-Sabará (o "lado de lá" do divisor de águas) levantaram objeções ao traçado original da expansão da Anita Garibaldi, em função de sua suposta descaracterização do bairro. $O$ traçado original da via atingiria equipamentos comunitários da região, como uma escola, uma praça, o Centro Comunitário Bairro Ipiranga, uma figueira centenária, etc. Em uma série de reuniões entre representantes da Região de Planejamento local e integrantes da Secretaria Municipal de Planejamento e da EPTC (Empresa Pública de Transporte e Circulação), os moradores propuseram alternativas ao traçado original, tentando contemplar a preservação de algumas das singularidades do seu bairro ${ }^{110}$. Na primeira reunião, realizada em 24/11/1999, os moradores elencaram algumas preocupações com a expansão prevista, entre as quais destacam-se: (1) a importância da preservação das áreas verdes; (2) o descontentamento com o eixo Anita Garibaldi, formador do Corredor de Centralidade Anita-Nilo. Enquanto que em alguns momentos houve disposição de alguns setores da Secretaria de Planejamento em encontrar uma posição conciliatória entre as reivindicações dos moradores e o traçado original, o problema foi, por outras vezes, tratado como puramente "técnico". Em reunião na Secretaria do Planejamento Municipal (07/01/2000), a posição de uma engenheira é explícita, como revela a ata da reunião: para ela, "a definição de um Eixo é um assunto essencialmente técnico, e não deve ser discutida com a comunidade".

Ainda na sua tentativa de alterar a rota da extensão do corredor Anita Garibaldi, os moradores participaram da $1^{\text {a }}$ Conferência de Avaliação do Plano Diretor em 2003 e, através desta, recomendaram novamente a alteração do traçado da futura via, em função do impacto ao modo de vida dos habitantes do local, recomendação que foi aprovada pela plenária. Quando do encaminhamento do texto final do projeto de lei que altera 86 artigos do Plano Diretor de Desenvolvimento Urbano e Ambiental, e que atualmente tramita na Câmara dos Vereadores, novamente os moradores se manifestaram, em audiências públicas, através da Associação dos Moradores do Bairro Jardim

\footnotetext{
${ }^{110}$ Agradecemos ao Prof. Paul Dieter Nygaard, da PUC/RS, por ceder-nos atas de reuniões com os Fóruns Regionais de Planejamento na época da aprovação do Loteamento Germânia, processo do qual foi participante, relativas à discussão a respeito da expansão do eixo viário da Anita Garibaldi.
} 
Itu-Sabará e Hospital de Olhos, exigindo um reestudo do traçado previsto para a radial. Os moradores justificam a necessidade da revisão e recordam que a proposta foi acolhida quando da realização da Conferência em 2003, mas desconsiderada em seguida, sem que qualquer estudo tenha sido realizado. A Prefeitura Municipal argumenta que a Secretaria Municipal do Planejamento "reafirmou tecnicamente e manteve o traçado original do eixo Anita Garibaldi"111.

Assim, mesmo contra seu desejo, os moradores viram sua proposta de alteração do traçado do eixo ser rejeitada sob argumentos "técnicos" da Secretaria do Planejamento, pois a alteração do traçado retiraria o sentido de "corredor" que o Plano Diretor conferira à Anita Garibaldi. A necessidade de circulação, encarnada na abertura de vias largas e de fácil escoamento do tráfego, configura um cenário em que as soluções para a cidade aparecem como soluções puramente "técnicas". "O automóvel (...)", diz Ana Fani Carlos (2001, p. 131), "vai determinando os horizontes e limites do planejamento que visa a busca da 'eficácia técnica' da cidade, em que a necessidade de investir no sistema viário se articula com os interesses dos setores econômicos da metrópole". Assim, o Estado cria as condições para a transformação do espaço em valor de troca, o que tem por efeito a tendência à afirmação de um espaço homogêneo que restringe as possibilidades do uso, da apropriação ${ }^{112}$.

Enfim, a intensidade em que a vida do bairro Vila Ipiranga será afetada pela expansão do eixo valorizado ainda não pode ser vislumbrada, visto se tratar de um processo incipiente. São poucas as chances, contudo, de que o cotidiano dos moradores do bairro não seja de alguma forma negativamente atingido pela imposição do espaço abstrato a partir da articulação Estadocircuito secundário.

\footnotetext{
${ }^{111}$ Grifo nosso. Ata de audiência pública para avaliação de propostas das comunidades de moradores. Referência:

112 http://lproweb.procempa.com.br/pmpa/prefpoa/spm/usu doc/gt2audiencia.pdf

112 Para Damiani (2001, p. 54), para "decifrar os conteúdos complexos do espaço social", cumpre "[decifrar] o espaço social reduzido ao espaço "puro", frio, como estratégia, reduzindo seus conteúdos. Mediação perturbadora, impedindo a vida, o sentido da vida".
} 
5.6. A concentração do poder econômico como necessidade para a obtenção de lucros de incorporação

Merecem ser registradas aqui algumas observações, em primeiro a respeito do setor imobiliário em geral e, em seguida, sobre o deslocamento das centralidades de Porto Alegre para, então, concluirmos o capítulo. A primeira observação que deve ser reiterada, caso não tenha ficado evidente que este é um dos processos mais significativos do ponto de vista da produção do espaço pelo circuito secundário hoje, é que estamos diante de uma reestruturação do setor imobiliário que acarretou uma concentração de capital bastante acentuada ${ }^{113}$. Esse capital imobiliário, muitas de cujas empresas mais representativas abriram capital recentemente na Bovespa, tem criado condições para se beneficiar de uma nova "fronteira" aberta nos anos recentes, que se situa nos imóveis destinados à classe média baixa em bairros mais afastados, fronteira esta que foi aberta pela expansão do crédito, como vimos acima. Não dispondo, muitas vezes, do know-how do qual dispõem as maiores empresas nacional do setor, a maioria das quais com sede em São Paulo, as empresas gaúchas têm estabelecido parcerias, muitas vezes na forma de jointventures, para seguir atuando com competitividade no mercado local. Em certos casos, o foco da parceria é para atuação no chamado "mercado econômico", enquanto que em outros a parceria revela-se como uma estratégia das empresas paulistas de entrar no mercado local de imóveis de luxo. A Tabela 5 mostra as principais empresas de atuação nacional que se estabeleceram recentemente no mercado local, bem como sua maneira de atuação e o mercado ao qual se destinam (optamos por manter a denominação "econômico" e "alto padrão" utilizadas pelos próprios empreendedores). Convém assinalar que a empresa Rossi entrou sozinha, em 2001, no mercado gaúcho, para atuar no mercado econômico, e somente estabeleceu parceria para atuar no mercado de alto padrão, com a Melnick, em 2006, parceria já desfeita uma vez que esta última passou, em 2008, a atuar em conjunto com a Even. O oposto ocorre com a Goldsztein e a Capa, que mantêm sua

\footnotetext{
${ }^{113}$ Um trabalho importante sobre os caminhos que levam à concentração do setor é o de Michael Ball (1983). Mesmo que o autor esteja mais preocupado com o caso inglês, suas considerações são de grande relevância para entender a dinâmica do setor da incorporação.
} 
independência no mercado de alto padrão, mas estabelecem parcerias para o mercado de menor padrão.

Tabela 5 - Atuação de empresas com escala nacional no mercado local

\begin{tabular}{|l|c|c|c|c|}
\hline $\begin{array}{c}\text { Forma de } \\
\text { atuação }\end{array}$ & Empresa & Parceria local & $\begin{array}{c}\text { Mercado } \\
\text { atendido }\end{array}$ & $\begin{array}{c}\text { Ano de } \\
\text { entrada }\end{array}$ \\
\hline Parceria & $\begin{array}{c}\text { Rodobens } \\
(\text { SP) }\end{array}$ & Capa & Econômico & 2007 \\
\hline Parceria & Cyrela (SP) & Goldsztein & Econômico & 2005 \\
\hline Parceria & Gafisa (SP) & Ivo Rizzo & Alto padrão & 2006 \\
\hline Parceria & InPar (SP) & CFL & Alto padrão & 2007 \\
\hline Parceria & Even (SP) & Melnick & $\begin{array}{c}\text { Alto Padrão e } \\
\text { econômico }\end{array}$ & 2008 \\
\hline $\begin{array}{l}\text { Parceria e } \\
\text { individual }\end{array}$ & Rossi (SP) & Melnick & Alto padrão & 2001 \\
\hline $\begin{array}{l}\text { Individual } \\
\text { Tenda (MG) }\end{array}$ & - & Econômico & 2008 \\
\hline Individual & MRV (MG) & - & Econômico & 2008 \\
\hline Fonte: consulta aos sites das referidas empresas. & & \\
\hline
\end{tabular}

Soma-se a isso uma incipiente onda de fusões e aquisições no setor que levou, por exemplo, à compra de $60 \%$ da construtora Tenda pela Gafisa ${ }^{115}$ e a compra da empresa Company pela Brascan ${ }^{116}$, apesar da aparente dificuldade que algumas empresas que abriram capital vêm apresentando ${ }^{117}$. Assim, embora o setor continue, como sempre, a ser caracterizado por uma infinidade de pequenas empresas, são as grandes empresas as que são capazes de manipular o direcionamento da expansão da valorização, de construir fronteiras de valorização que reconfiguram o espaço urbano. Seu crescente poder de mercado proporciona-Ihes um giro mais acelerado do capital - o que significa uma taxa anual de lucro mais elevada -, dilui os riscos relacionados com

\footnotetext{
${ }_{114}^{114}$ A Tenda foi adquirida em agosto de 2008 pela Gafisa.

115 Valor Econômico. Gafisa compra Tenda e tira construtora da crise. São Paulo, 02/set/2008, capa.

116 "Brascan confirma compra da Company". Portal Exame (www.portalexame.abril.com.br), 10/09/2008.

${ }^{117}$ Folha de S. Paulo. Após abertura de capital, construtoras têm dificuldade. São Paulo, 3 de setembro de 2008, p. B5.
} 
flutuações de mercado, devido à diversificação de investimentos, abre-lhes acesso ao uso mais intensivo de tecnologia e ao investimento mais pesado em publicidade e, por fim, permite-lhes construir um land bank (banco de terras) através do qual o volume da produção pode ser aumentado ou diminuído com maior rapidez e os custos do terreno no preço final são diminuídos - compra-se o terreno muito antes de sua utilização, o que, muitas vezes, significa que no momento de utilização a renda potencial sofreu alteração para cima ${ }^{118}$.

Enfim, duas coisas ficam claras, também, como conseqüência dessa acentuada concentração do capital imobiliário. Em primeiro lugar, evidencia-se que escala mínima de atuação das empresas cresce para o setor, e expandir se tornou menos uma opção e mais uma necessidade. Assim, a abertura de capital na Bolsa de Valores capitalizou as empresas para abrir novas "frentes", abrangendo várias metrópoles e cidades médias no Brasil. E, para as empresas que atuavam no mercado local da metrópole gaúcha, a parceria com as empresas de escala nacional significou, portanto, o acesso a essa maior capitalização. Isso fica evidente neste trecho de nossa entrevista com a Goldsztein:

Eu posso te dizer, assim: a Goldsztein, até 2005, atuou sozinha, aqui em Porto Alegre, sem a joint venture com a Cyrela e ela sempre foi uma empresa líder de mercado aqui, em termos de faturamento, em termos de tecnologia de construção, sempre foi uma empresa que buscou inovação, crescimento, e por muito tempo acho que ela liderou o mercado. De 2005 para cá, já na década de 1990 a Rossi veio para Porto Alegre, e veio com parceria com a Goldsztein, com o Plano 100 e, depois de desfeita essa parceria do Plano 100, a Rossi se estabeleceu com uma filial em Porto Alegre, sozinha. Sempre foi uma forte concorrente, porque a Rossi era uma filial de uma empresa de São Paulo, e em São Paulo sempre o mercado é muito mais evoluído, as primeiras coisas vêm de São Paulo e acontecem em São Paulo. E, em 2005, as grandes construtoras e incorporadores de São Paulo abriram [capital] na Bolsa, IPO [Initial Public Offering], e a Cyrela, a Gaffisa, a InPar, a MRV, as maiores de São Paulo abriram o mercado e como isso elas tinham uma meta para se expandir, crescer. E foi aí que a Goldsztein viu que as grandes iam vir para Porto Alegre também e houve o convite da Cyrela de fazer uma joint venture com a Goldsztein, e a Goldsztein, de 2006 para cá, cresceu muito em função da joint venture com a Cyrela. Então, eu te digo que de 2005 para 2006 o faturamento dobrou, de 2006 para 2007 o faturamento dobrou e de 2007 para 2008 o faturamento está dobrando, sempre dobrando em relação ao ano anterior. Isso foi um crescimento muito grande, por exemplo, como um todo na empresa, como volume de obras, como volume de empreendimentos lançados, como volume de terrenos comprados, como efetivo de funcionários

${ }^{118}$ Cf. Ball (1983) 
da empresa. Basta ver que até dezembro de 2005 eu trabalhava sozinha. Hoje a minha equipe é uma equipe de 11 pessoas, eu e mais 10. $\mathrm{E}$ assim foram todos os setores da empresa: a contabilidade, a tesouraria, o pessoal de contratos, a área comercial, marketing, etc. Houve uma expansão muito grande em função do volume. Isso se deu muito por essa entrada de capital no País, e esse crescimento não foi só aqui. Esse crescimento foi em São Paulo, no Norte, Nordeste, Rio de Janeiro, Minas, muito grande, e houve também, se abriu um mercado há muito tempo estagnado em função dos juros, da possibilidade de se fazer imóveis para uma população de mais baixa renda e é isso que está crescendo e este é o grande nicho, o grande crescimento hoje do nosso mercado. Então, em especial eu acredito, porque eu acho que nos empreendimentos de médio, alto padrão, eu acho que a evolução não é tão grande. Eu acho que o crescimento maior deu-se pelas grandes áreas nas periferias, áreas mais nas zonas mais populares e com isso, [queremos] abranger esse nicho de mercado, uma construção diferente. Nós que éramos uma construtora muito de médio e alto padrão, estamos hoje abrindo esse mercado dentro da empresa.

Portanto, a Goldsztein soma-se ao poder de capitalização oferecido pela Cyrela para se inserir nesse novo "nicho", que é o mercado de renda médiabaixa e assim ela aumenta a escala de sua atividade, o que aparece também sob a forma de um aumento do faturamento. O crescimento dos grandes grupos atuando no setor confirma, ademais, que o investimento no circuito secundário revela-se uma opção bastante rentável no capitalismo tardio, e é por isso que muitas empresas monopolistas de outros setores, como é o caso da Rodobens (que atua no setor de seguros, bancos, comercialização de caminhões e máquinas agrícolas e locação de veículos ${ }^{119}$ ), acabam por abrir subsidiárias no setor imobiliário como forma de escoar capital excedente. Isso não é exclusividade do momento atual, uma vez que, como vimos, muitas empresas no início do século XX atuavam ativamente no mercado de terras. Mas sua atuação era fundamentalmente diferente do que Ball (1983) chamou de "moderna indústria de construção especulativa de moradias"120, de maneira que hoje especulação imobiliária, incorporação e construção não se separam mais, como a própria conceituação de Ball sugere. A potencialização das capacidades de investimento é também ressaltada por Vanderlei Tamiosso, da incorporadora gaúcha Capa, que recentemente estabeleceu parceria com a gigante Rodobens para atuar no mercado local, especialmente no setor de renda médio e médio-baixo. Tamiosso afirma que

\footnotetext{
${ }^{119}$ Consulta ao site da empresa (www.rodobens.com). O caso do Grupo Jereissati, proprietário da empresa Iguatemi de administração de shopping centers, representa um caso semelhante. ${ }^{120}$ Uma tradução um pouco desajeitada de "modern speculative housebuilding industry".
} 
"[...] [o] mercado estava com crescimento vertiginoso e a economia estabilizada com bons fundamentos. [Então], algumas incorporadoras do centro do país (São Paulo), nos procuraram para realizarmos parcerias. A nossa escolha pela Rodobens se deu por diversas sinergias positivas que as empresas possuíam, assim fica mais fácil a soma das competências de cada organização.

As parcerias são indispensáveis para o crescimento das empresas, tanto competências como crescimento das mesmas. Assim, as parcerias de soma são as que podem proporcionar os melhores produtos com melhores preços, melhores condições aos adquirentes e melhor parceria com os agentes financeiros."

\section{Ainda para Tamiosso, depois da parceria com a Rodobens}

[...] os volumes de negócios se multiplicaram, uma nova filosofia e política de preços foi implantada e os produtos buscam sempre a melhor relação custo/benefício. A principal mudança é a mudança de escala de produção.

E o segundo ponto, que também é manifestado na entrevista com a Goldzstein e que, em nosso ver, constitui elemento fundamental dessa etapa da urbanização brasileira é a centralidade de São Paulo. De fato, como a entrevistada colocou, tudo acontece e tudo vem de São Paulo. As reestruturações econômicas pelas quais o País tem passado nos últimos quinze anos traduziram-se no reforço da centralidade de comando da metrópole paulistana, conferindo atualidade à seguinte afirmação de Henri Lefebvre:

(...) a kind of overall colonization of space by 'decision-making centers' seems to be taking shape. Centers of wealth and information, of knowledge and power, are beginning to create feudal dependencies. In this case, the boundary line does not divide city and country but cuts across the urban phenomenon, between a dominated periphery and a dominating center ${ }^{121}$ (LEFEBVRE, 2003, p. 133)

São Paulo centraliza, portanto, a gestão da economia nacional, controlando a disposição do trabalho excedente obtido sob a forma de maisvalia e direcionando-o para onde o reinvestimento se mostrar mais rentável ou onde houver novos mercados a serem explorados. Isso não significa dizer que certos processos não possam ocorrer simultaneamente em diferentes lugares.

\footnotetext{
121 “(...) uma espécie de colonização completa do espaço pelos centros de decisão parece estar tomando forma. Centros de riqueza e informação, de conhecimento e poder, estão começando a criar dependências feudais. Neste caso, a linha divisória não separa a cidade do campo, mas atravessa o fenômeno urbano, entre uma periferia dominada e um centro dominante". Tradução nossa. Cf. também Lefebvre (2002).
} 
Não se trata aqui de propugnar a existência de uma espécie de difusão do moderno que parte de São Paulo e se espalha pelo restante do território, mas sim do fato de que a capital paulista tende sempre a atrair para si o comando administrativo das atividades que atingem um alcance nacional ou internacional, razão pela qual Milton Santos (2005, p. 59) afirma que São Paulo é a metrópole onipresente no território brasileiro ${ }^{122}$. Esse é um processo importante que, como mostrou Henri Lefebvre no trecho acima, configura uma das contradições mais fundamentais do espaço na sociedade urbana, aquela entre centro e periferia (superando, portanto, a antiga contradição entre campo e cidade). Vimo-nos na necessidade de comentar isso em função da sua evidência no caso estudado, mas está para além dos objetivos desse trabalho desenvolver com maior profundidade as considerações a respeito do tema.

Para finalizar o capítulo, ainda é preciso aprofundar nosso entendimento no que tange à interferência do Estado no processo de deslocamento do eixo valorizado de Porto Alegre para Leste. Isto porque, se restringirmos a influência do Estado nesse processo somente à área do Jardim Europa, estaremos negligenciando outras formas de intervenção.

Julgamos de fundamental importância nesse processo de produção de uma nova centralidade a consolidação da Avenida Carlos Gomes como eixo dos negócios na metrópole. Esta avenida vem recebendo, nos últimos 10 anos, uma série de investimentos comerciais (edifícios corporativos e de escritórios de alto padrão) que permitiram a instalação de escritórios de gestão empresarial e bancos no local. A importância crescente da avenida tem atraído, ademais, hotéis, restaurantes e outros empreendimentos para o local, um processo que ainda está relativamente incipiente, visto que existem ainda muitos terrenos passíveis de incorporação. Mas a avenida não teria sua função de eixo de negócios consolidada se não fosse o altíssimo investimento envolvido no alargamento de avenidas que permitiu a efetivação da III Perimetral, conjunto de avenidas interligadas que une o Aeroporto Salgado

\footnotetext{
${ }^{122}$ Para esse autor, "[...] São Paulo passa a ser a área polar do Brasil, não mais propriamente pela importância de sua indústria, mas pelo fato de ser capaz de produzir, coletar, classificar informações, próprias e dos outros, e distribuí-las e administrá-las de acordo com seus próprios interesses" (SANTOS, M., 2005, p. 59). Em outro trecho, o autor afirma que "atividades modernas, presentes em diversos pontos do país, necessitam apoiar-se em São Paulo para um número crescente de tarefas. São Paulo fica presente em todo o território brasileiro, graças a esses novos nexos, geradores de fluxos de informação indispensáveis ao trabalho produtivo" (SANTOS, M., 2005, p. 100).
} 
Filho e a rodovia conhecida como Free-way, no extremo Norte do município, à Zona Sul ${ }^{123}$. A acessibilidade rápida do aeroporto para os hotéis de alto padrão instalados na avenida, bem como o acesso, pela via, às principais rodovias que levam aos outros municípios da metrópole e a outras cidades têm atraído os negócios terciários para o local, que já disputa com o bairro Moinhos de Vento no que tange ao abrigo dessas funções. A valorização dos terrenos adjacentes ao trecho da Avenida Carlos Gomes (Figuras 12 e 13) e da Avenida Dom Pedro e geração de empregos no terciário superior neste local impulsionaram, por sua vez, a valorização ainda mais intensa dos bairros situados a Leste e a Oeste do eixo. A produção de escritórios modernos, como conseqüência, tem extravasado para o lado do Iguatemi, sobretudo na Avenida Nilo Peçanha.

Não foi possível, contudo, aprofundar a pesquisa sobre a constituição desta avenida, mesmo porque, como foi assinalado no primeiro capítulo, a intenção do trabalho era outra. Contudo, a vultosa obra da III Perimetral é digna de menção na medida em que sua consolidação também ajudou a empurrar para cima o preço da terra nas suas áreas próximas, o que inclui a região do Jardim Europa.

${ }^{123}$ Enquanto que as radiais fazem o trajeto oeste-leste, as perimetrais cortam a cidade de norte a sul. 


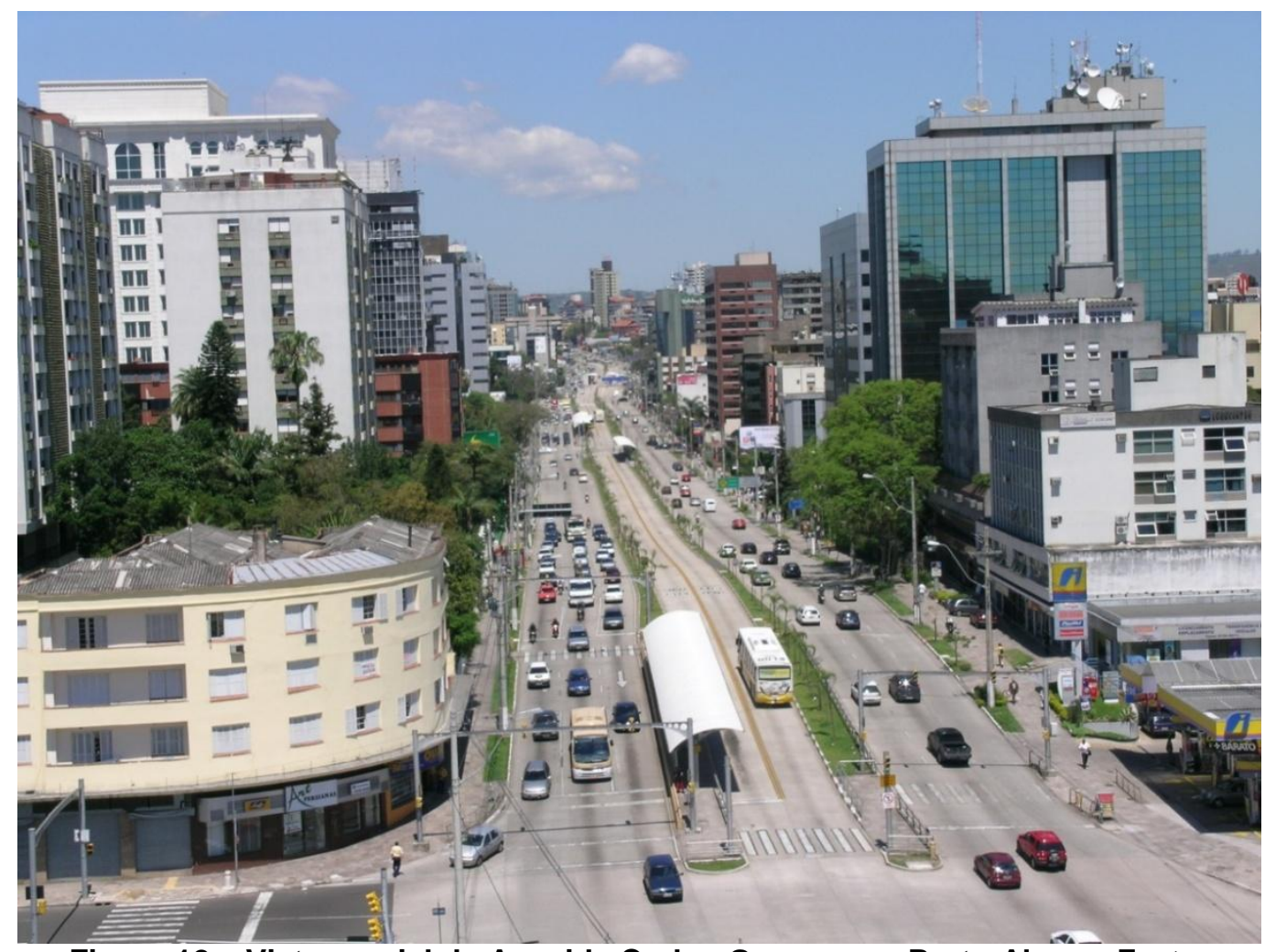

Figura 12 - Vista parcial da Avenida Carlos Gomes, em Porto Alegre. Fonte: http://www.panoramio.com/photo/12778881 (Acesso em 26/01/2009)

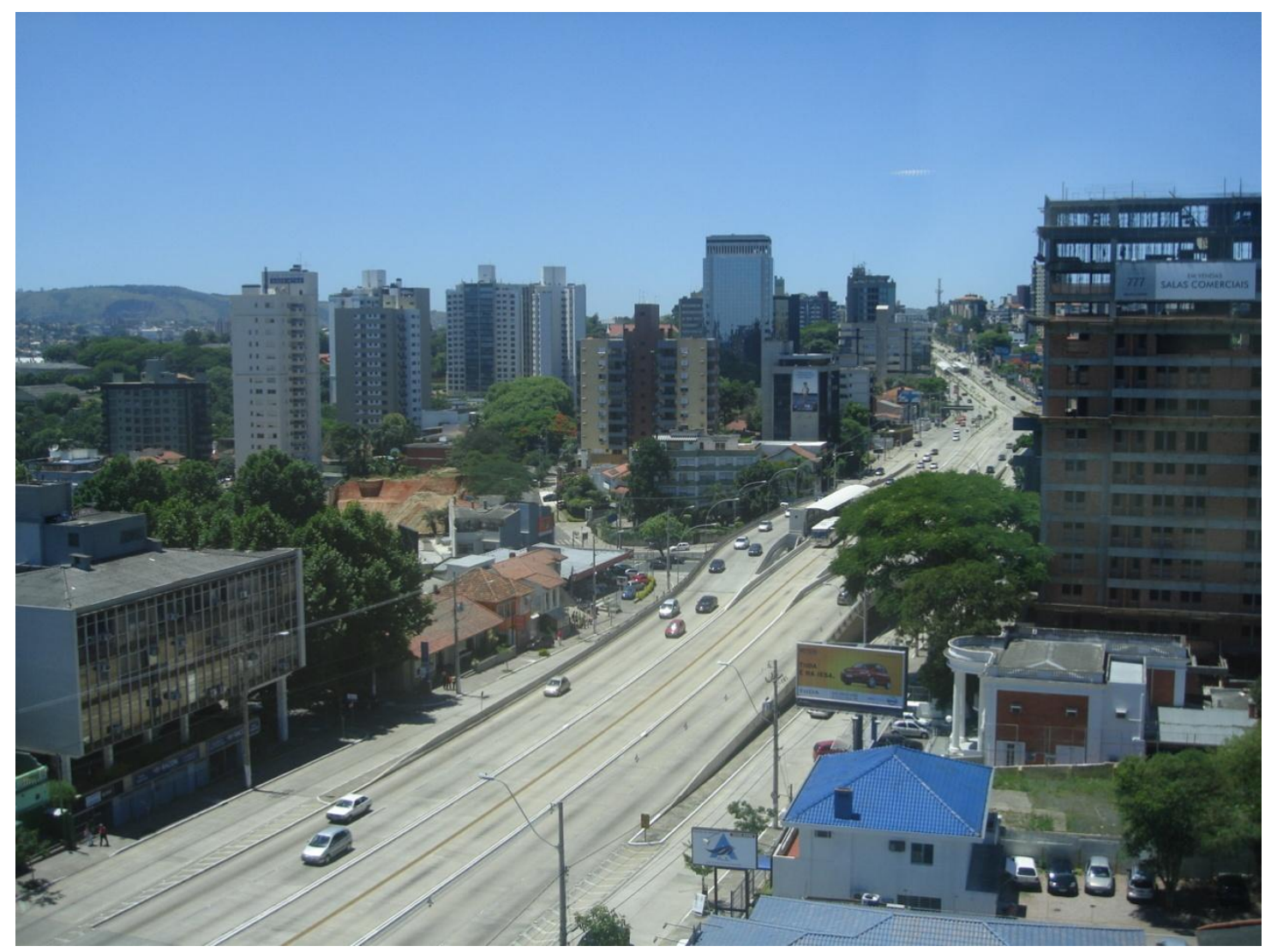

Figura 13 - Vista de trecho da Avenida Carlos Gomes. Fonte:

http://www.flickr.com/photos/manhattan104/2130874605/ (Acesso em 26/01/2009) 


\section{Estado, circuito secundário e consumo dirigido: considerações finais sobre a produção do espaço da metrópole sob o signo do neoliberalismo}

Curieux espace: homogène et composé de ghettos. Transparent et faux: piégé. Faussement vrai, "sincère": non pas object d'une fausse conscience, mais au contraire, lieu et milieu engendrant (produisant) la fausse conscience.

Henri Lefebvre

La tendence presente à la liquidation de la ville ne fait [...] q'exprimer d'une autre manière le retard d'une subordination de l'économie à la conscience historique, d'une unification de la société ressaisissant les pouvoirs qui se sont détachés d'elle.

Guy Debord

O fechamento da pesquisa desenvolvida, cujo resultado foi exposto nas páginas acima, não é senão um fechamento relativo, ou talvez seja o caso de pensar que o caminho percorrido proporcionou novas aberturas. Assim, o uso do termo "considerações finais" fica relativizado, pois o impulso que embasou o presente trabalho, qual seja, o de compreender como ocorre a produção da metrópole no atual estágio do desenvolvimento capitalista no Brasil, permitiunos lançar algumas hipóteses, fundamentá-las com algumas evidências, mas de forma alguma fornecer respostas finais. Este último capítulo deve, então, retomar alguns aspectos discutidos ao longo do trabalho, de forma a dar mais coerência ao conjunto das hipóteses e idéias desenvolvidas nas páginas anteriores. Durante o trabalho, foram discutidos vários elementos que atuam 
sobre a produção imobiliária e a complexa interpenetração das escalas talvez tenha sido um dos aspectos menos bem esclarecidos. Acreditamos, contudo, que o cerne do trabalho consistiu em compreender como se formam as centralidades de valorização na metrópole e, conseqüentemente, como essas centralidades, que, inexoravelmente, formam um par dialético com as múltiplas periferias, são produzidas, imprimindo uma segregação acentuada no espaço da metrópole. É preciso frisar que esse processo possui múltiplas facetas, só algumas das quais foram exploradas aqui. "Le movement 'centralitéperiphérie'", diz Henri Lefebvre, "est [...] hautement complexe. II met em jeu et la logique et la dialectique dans leur double détermination" (LEFEBVRE, 2000a, p. 384$)^{124}$. Voltamos, aqui, portanto, a discutir alguns aspectos dessa produção de centralidades e, para tanto, aportaremos a contribuição de alguns autores que se dedicaram ao problema.

Para retomar o que foi dito em vários momentos do trabalho, acreditamos que o circuito secundário, hoje principalmente representado pelo grande capital incorporador, com o apoio do Estado, avança, através dos seus investimentos, sobre áreas menos valorizadas da cidade, originando novas fronteiras urbanas. A constituição dessas fronteiras atua no sentido de alterar a distribuição espacial das classes sociais no espaço urbano, atraindo, para novas áreas, setores da classe média e alta que outrora habitaram outros bairros. As estratégias envolvidas nas fronteiras urbanas requerem a oferta de atrativos para as classes média e alta e, com o recurso à publicidade maciça, 0 capital incorporador cria novas necessidades, confere uma exclusividade ao produto ofertado ao atribuir-lhe signos relacionados com modernidade, felicidade, harmonia com a natureza, etc. Produz-se, assim, uma interminável "reciclagem" de bairros, em que valorização e desvalorização formam um par dialético e, desta forma, a cidade vai sendo moldada pela necessidade da acumulação de capital. Em Porto Alegre, esse processo deu origem a um nítido eixo valorizado, que vem se formando desde o fim do século XIX, que parte do Centro em direção a leste. Com a valorização observada nos bairros Passo da Areia, Cristo Redentor, Vila Jardim e Vila Ipiranga, constitui-se uma tendência ao avanço do eixo valorizado para leste, processo para cujo desenvolvimento

\footnotetext{
124 "O movimento 'centralidade-periferia' é [...] altamente complexo. Ele coloca em jogo tanto a lógica quanto a dialética em sua dupla determinação". Tradução nossa.
} 
concorrem investimentos públicos (vias, linhas de transporte, etc) e privados (shoppings, lojas de alto padrão, escritórios, etc) na área. Por outro lado, ganha impulso também a formação de uma configuração espacial própria do eixo Sul da cidade, na borda do Guaíba, para o qual demos menos atenção, mas que, em função da construção de um shopping center pelo grupo Multiplan - uma das maiores empreendedoras de shoppings no Brasil - sofre intensa especulação e valorização na área próxima ao Hipódromo (bairro Cristal).

Acreditamos que este padrão de segregação sócio-espacial é, em grande medida, produto de forças bastante anárquicas, embora a presença do Estado seja imprescindível para a obtenção de lucros de incorporação. Sendo assim, parece haver certa dose de funcionalismo na tese de Flávio Villaça (2001) de que a segregação sócio-espacial existe porque responde às necessidades de dominação da classe dominante. De fato, o padrão segregado permite o controle do espaço e do tempo pela classe dominante, que se apropria da centralidade (ou das centralidades) que são a essência do urbano. Entretanto, essa segregação ocorre não porque a burguesia decidiu que este seria o padrão melhor para sua dominação, mas sim como um produto da articulação entre circuito secundário e o Estado, como Gottdiener (1994) sugeriu, sem que se tenha uma decisão centralizada.

Ainda segundo Villaça (2001, p. 339-41), a segregação tende a produzir uma única região geral da cidade destinada às classes de alta renda (em São Paulo, o quadrante sudoeste; no Rio de Janeiro, a zona Sul; em Porto Alegre, o setor Centro-leste, etc). De fato isso tende a ocorrer ${ }^{125}$, mas esse processo deve muito às forças anárquicas da articulação circuito secundário-Estado, e Gottdiener parece ter destacado com muita propriedade este aspecto pouco coordenado do mercado. Assim, as fronteiras urbanas tendem a seguir na mesma direção do eixo valorizado, em virtude de estar para além da possibilidade do capital individual o poder de produzir as centralidades de serviços, empregos e comércio das quais a classe dominante deseja estar próxima. Assim, as fronteiras se constituem entre "a segurança da Gold Coast" e a "cidade selvagem" da desvalorização e do desinvestimento, para lembrar Neil Smith, porque aqueles que vão habitar a fronteira não estarão tão

\footnotetext{
${ }^{125}$ É somente uma tendência, porque, para tomar um exemplo, a Zona Sul de Porto Alegre também tem se valorizado bastante nos últimos anos, como já mencionamos.
} 
afastados das centralidades das quais desejam usufruir - e aqui podemos ver uma espécie de efeito de inércia que o espaço produzido no passado exerce sobre a produção do espaço no momento atual. Quando essas fronteiras se constituem distantes, ou elas oferecem toda espécie de serviços compensatórios - o condomínio Terra Ville, no extremo Sul de Porto Alegre, distante do eixo valorizado, oferece uma "filial" do tradicional Colégio Farroupilha, uma Escola de Inglês, lojas e serviços como locadora, academia e armazém, e um serviço particular de transporte que liga o empreendimento ao shopping Moinhos de Vento ${ }^{126}$; o Alphaville de São Paulo oferece muito mais ou permitem uma acessibilidade rápida à maior centralidade de valorização da cidade, como é o caso dos subúrbios americanos, articulados ao Central Business District (CBD) por vias expressas ${ }^{127}$. Sem dúvida o Estado contribui nesse processo de segregação, ao proporcionar uma infra-estrutura mais completa nas áreas valorizadas, mas isso ainda não permite que afirmemos que a segregação existe porque é melhor para a dominação.

Enfim, deve ser relativizada também a afirmação de Flávio Villaça de que a burguesia escolhe o local de moradia. É verdade que, ao criticar as teorias do uso do solo neoclássicas, fundadas na soberania do consumidor, seria absurdo cometer o mesmo erro, propugnando uma espécie de "soberania do produtor". Oferta e demanda, valor de troca e valor de uso, devem ser entendidos como dialeticamente articulados, como dois lados da mesma moeda, como sempre enfatizou Marx. Mas se, em função dos desejos da demanda das classes de alta renda, o mercado imobiliário não dispõe de livre criação no momento de ofertar um produto - imóveis ofertados próximo a áreas muito pobres, por exemplo, dificilmente atraem famílias de segmentos de alta renda -, por outro lado pode-se afirmar que as famílias de alta renda seguem, em grande medida, as linhas gerais determinadas pela atividade do capital incorporador e da publicidade que produz novas necessidades, veiculando certos signos do morar bem e da qualidade de vida. É assim que um bairro

\footnotetext{
${ }^{126}$ Cf. Ueda (2005).

127 Ainda assim, é importante notar que os projetos de construção maciça de casas em subúrbios americanos quase sempre vêm acompanhados da produção de alguma centralidade comercial, como os shopping centers. O fato de que a concentração do capital imobiliário, e por conseguinte o poder econômico, nos Estados Unidos seja ainda mais acentuado dá mais liberdade ao capital em direcionar o crescimento urbano para determinadas áreas.
} 
como o Jardim Europa, ainda em certa medida "distante" de muita coisa no que se refere aos desejos de consumo da elite, consegue atrair famílias de bairros valorizados tradicionais da cidade.

Por outro lado, concordamos com Villaça no que tange ao poder estruturador dos bairros residenciais de alta renda no conjunto do espaço urbano, embora talvez a relação de causalidade estabelecida pelo autor, segundo a qual as centralidades de empregos (escritórios, sedes de empresas e bancos) seguem a direção da valorização residencial, não seja tão nítida. Isso porque parece haver um efeito de simbiose entre a valorização residencial e valorização comercial e corporativa, sem que possa ser apontada uma nítida relação de causa e efeito ${ }^{128}$. Mas é visível, como mostra Villaça (2001), que produção dos bairros das camadas de alta renda define as centralidades a partir das quais resulta a superfície diferencial da renda do solo urbano e definem-se as possibilidades de ocupação do espaço pelas outras classes sociais, menos privilegiadas do ponto de vista do controle do espaço e do tempo urbano, como pertinentemente sublinha o autor.

A teoria proposta por Pedro Abramo (2007), ainda que ofereça muitas contribuições relevantes, parece ignorar o papel exercido por uma certa inércia do espaço, como ressaltamos pouco acima. Abramo preconiza a formação de preços do solo urbano por convenção, o que parece sugerir que uma súbita e completa transformação da configuração do espaço intra-urbano seja possível, bastando para isso que se estabeleça uma nova convenção. Dificilmente isso é viável, e este é o problema de se equiparar o funcionamento do mercado financeiro com o do mercado de terras da maneira como o autor fez - ou seja, a volatilidade e instabilidade não assumem, no mercado de terras, as mesmas proporções que o fazem no mercado financeiro. Por outro lado, Abramo parece reconhecer dois elementos aos quais o presente trabalho deve tributo: o primeiro é o fato de que as empresas do setor imobiliário possuem, em larga medida, um poder fundamentalmente maior na estruturação do espaço intra-

\footnotetext{
${ }^{128}$ O exemplo da Avenida Carlos Gomes, em Porto Alegre, é instrutivo, como vimos. O deslocamento recente do centro corporativo (escritórios, bancos, etc) da metrópole para o local pode ter sido em parte "puxado" pela valorização de bairros residenciais próximos, como - Bela Vista e o Três Figueiras. Mas sua consolidação, por sua vez, teve efeitos de valorização sobre esses mesmos bairros e sobre outros ainda. Talvez o caso da Av. Berrini, no quadrante Sudoeste de São Paulo, represente um caso semelhante, pois os escritórios modernos têm impulsionado a valorização de bairros como Santo Amaro, em sua parte mais ao norte.
} 
urbano do que as famílias enquanto consumidoras; o segundo reside na importância, atribuída pelo autor, à inovação (criação de novos produtos), por parte das empresas do setor, como forma de obter sobrelucros de incorporação.

O trabalho também deixou claro que a produção do espaço urbano, como um processo desenfreado de "reciclagem" do solo urbano a fim de transformá-lo em valor de troca, sustenta-se, em última análise, no desperdício - como de fato toda a economia capitalista depende crescentemente do desperdício. O que isso quer dizer é que, para atender às necessidades expansionistas do capital, o espaço urbano precisa ser permanentemente desvalorizado e revalorizado, precisa ingressar incessantemente no ciclo do capital, mesmo que através de uma obsolescência artificial - impelida pelo uso da publicidade - do estoque residencial existente ou através de sua destruição física. A idéia de que a economia capitalista apóia-se no desperdício parece entrar em contradição com a racionalidade capitalista da acumulação. Mas essa contradição é apenas aparente. O desperdício é funcional às determinações da valorização capitalista se ele ocorrer na esfera do consumo, depois da realização do valor. Isso porque, quanto menor o tempo de vida útil de um bem, mais rapidamente seu usuário deverá voltar ao mercado, mesmo que ao custo de um novo endividamento. Esse processo é alimentado pela ideologia do crescimento, que apresenta o crescimento quantitativo como sinônimo de desenvolvimento social, uma ideologia da qual faz uso o Estado para justificar seu estímulo ao produtivismo e à acumulação e, assim, contribui para a reprodução das relações sociais de produção. Para Lefebvre,

[...] on va jusqu'au bout pour maintenir la croissance. La destruction devient alors inhérente au capitalisme [...]. Pas seulement la violence declarée, civile ou militaire. Partout on organise l'obsolescence des objets, c'est-à-dire que la durée des objects, des produits industriels, est abrégée volontairement (LEFEBVRE, 2002, p. 107) ${ }^{129}$.

É por isso que Mark Gottdiener (1994) atribui tanta importância a uma crítica da ideologia do crescimento, sobretudo com o sentido de contrapor ao

129 "Vai-se até o limite para manter o crescimento. A destruição torna-se assim inerente ao capitalismo (...). Não somente a violência declarada, civil ou militar. Em toda parte, organizase a obsolescência dos objetos, ou seja, que a duração dos objetos, dos produtos industriais, é abreviada intencionalmente". Tradução nossa. Sobre a ideologia do crescimento, cf. também Gottdiener (1994). 
crescimento quantitativo o que Lefebvre entendeu por desenvolvimento (qualitativo). Uma crítica nesse sentido requer que esta lógica seja combatida por uma prática que encare efetivamente a cidade como valor de uso, como apropriação, resistindo às investidas da articulação entre Estado e circuito secundário para produzir um espaço homogeneizado, neutralizado e segregador. Nas palavras de Henri Lefebvre:

[...] le développement, restitué dans sa plenitude, implique un enrichessement, une complexification non réduite des rapports sociaux. II est (il ne peut se dire que) qualitatif. II suppose création de formes de la vie sociale, de 'valeurs', d'idées, de façons de vivres, de styles. En um mot de différences (LEFEBVRE, 1970, p. 38) ${ }^{130}$.

Devemos, ademais, fazer alguns comentários sobre outra questão que apareceu somente de forma marginal ao longo do trabalho e que diz respeito à relação do mercado imobiliário com a questão habitacional. Como foi frisado em vários momentos da exposição, houve, nos anos recentes, uma ampliação da oferta de financiamento imobiliário para estratos de renda antes dificilmente contemplados pelo sistema financeiro. Esta oferta ampliou as possibilidades de investimento lucrativo no ambiente construído, o que evidenciam o incremento no número de lançamentos e vendas nos mercados das principais metrópoles do país. Essa tendência tem sido exaltada pelos investidores do mercado financeiro e do circuito secundário como o caminho para a solução do desmesurado déficit habitacional do país.

A realidade é bem diferente do que desejam fazer crer os investidores que navegam nas correntes venturosas dos lucros de incorporação imobiliária. A expansão do crédito imobiliário, sem dúvida alguma benéfica para milhares de famílias que poderão ter acesso ao primeiro imóvel, deixa e continuará deixando de fora a maior parte das famílias, cujos rendimentos não estão aptos a contemplar a remuneração rentável do capital a juros emprestado na forma de hipotecas. A solução para o déficit habitacional, portanto, deve estar situada

\footnotetext{
130 "O desenvolvimento, restituído em sua plenitude, implica um enriquecimento, uma complexificação não reduzida das relações sociais. Ele é (ele não pode se dizer senão) qualitativo. Ele supõe a criação de formas da vida social, de 'valores', de idéias, de modos de vida, de estilos. Em uma palavra; de diferenças". Tradução nossa.
} 
fora dos mecanismos de mercado, da habitação como mercadoria e da remuneração lucrativa do capital financeiro, sobretudo em uma situação que aponta para uma financeirização da habitação ${ }^{131}$ - negociação de títulos de crédito hipotecário em mercados secundários. Por fim, é preciso ser dito que a expansão do crédito imobiliário, muito pouco coordenada do ponto de vista do seu direcionamento para fins sociais, acaba muitas vezes sustentando um processo desenfreado de "criação destrutiva" da cidade para retransformá-la, constantemente, em valor de troca, acarretando, muitas vezes, em excesso de investimento (GOTTDIENER, 1994, p. 261), como o exemplo recente dos Estados Unidos tornou visível. A tentativa de solucionar os problemas da economia através de um incentivo ao investimento no circuito secundário revela-se, em última análise, ilusória, e em determinado momento a expansão pelo crédito deve se deparar com o movimento da economia real (Harvey, 1999). No fim das contas, como apropriadamente ressalta David Harvey, "the land market necessarily internalizes all the fundamental underlying contradictions of the capitalist mode of production. It thereby imposes those contradictions upon the very physical landscape of capitalism" (HARVEY, 1999, p. 372$)^{132}$.

Esse problema também remete à postura que o Estado local tem assumido face aos problemas mais prementes da cidade. A liberalização e desregulamentação do comércio e dos investimentos tem sido responsável pela geração de um cenário de competição intra-urbana que força as cidades a entrar em uma guerra permanente no sentido de ofertar as melhores condições para os investimentos (o melhor business climate). Esse processo vem

${ }^{131}$ Cf. Botelho (2007). O documento "O crédito imobiliário no Brasil: caracterização e desafios" (2007), elaborado por uma equipe de economistas da FGV, defende enfaticamente uma maior liberalização do crédito, o fortalecimento da segurança jurídica dos contratos e a criação de uma ambiente institucional para securitização dos títulos imobiliários. Ainda assim, o documento admite que "para diminuir o elevado déficit habitacional do país, torna-se imperioso o estabelecimento de políticas específicas para atender as necessidades da população de baixa renda, com subsídios explícitos e dotações orçamentárias permanentes e em valores crescentes" (p. 40). A forma de atingir tal meta não parece, contudo, menos ilusória, visto que o documento sugere o requerimento de uma "poupança prévia" para aqueles que desejam obter financiamento subsidiado, um processo que teve como resultado, no Chile, a exclusão, do programa, de centenas de famílias que não podiam arcar com o custo dessa poupança prévia, como aparece no próprio documento. É difícil imaginar que uma família cujo rendimento mensal é igual ou até inferior a mil reais possa constituir uma poupança, por irrisória que seja.

132 "o mercado de terras internaliza todas as contradições subjacentes fundamentais do modo de produção capitalista. Ele impõe, portanto, essas contradições à própria paisagem física do capitalismo". Tradução nossa. 
acompanhado de uma descentralização do Estado, em que as atribuições do município crescem ${ }^{133}$.

Para proporcionar melhores condições de investimento para um capital que ganhou, nas últimas décadas, crescente mobilidade, os governos locais no Brasil têm se esforçado por investir nas infra-estruturas físicas e sociais que respondem aos interesses da acumulação de capital, em detrimento de políticas que possam atenuar os efeitos nefastos de uma desigualdade crônica e crescente. Esse processo tem um efeito disciplinador fundamental sobre as alternativas disponíveis aos governos locais, uma vez que atua como uma espécie de lei coercitiva de mercado à semelhança da que compele os capitalistas individuais a reinvestirem permanentemente a mais-valia que se origina no processo produtivo. É assim que

[...] most local governments have been constrained - to some degree, independently of their political orientation and national context - to adjust to heightened levels of economic uncertainty by engaging in short-termist forms of interspatial competition, place-marketing, and regulatory undercutting in order to attract investments and jobs" (BRENNER \& THEODORE, 2003, p. 20) ${ }^{134}$.

Essa ascensão de um empreendedorismo na gestão urbana, como Harvey havia observado já no final dos anos 1980, pode ser entendida como a forma específica de atuação do neoliberalismo na escala urbana, e é aqui que podemos amarrar as questões relativas à habitação com aquelas que dizem respeito ao recrudescimento dos processos de segregação sócio-espacial na escala urbana.

A ascensão repentina do neoliberalismo responde a uma série de pressões que nascem da queda acentuada da lucratividade no capitalismo tardio, sobretudo a partir da década de 1970. Essas pressões encaminham-se no sentido de impor uma série de reformas que operam em prol de uma

\footnotetext{
${ }^{133}$ Existe toda uma literatura na Geografia anglo-saxã que tem procurado interpretar os processos de rescaling, ou seja, as mudanças de escala predominante dos processos socioespaciais. Afirma-se que os anos recentes presenciaram uma diminuição da atuação do Estado na escala nacional em favor tanto da escala local quanto da supra-nacional, o que respondeu a processos variados. Cf. Brenner (2000); Gough (2004).

${ }_{134}$ "A maior parte dos governos locais tem sido forçados - em certa medida independentemente de sua orientação política ou contexto nacional - a ajustar-se a elevados níveis de incerteza econômica engajando-se em formas de competição inter-espacial de curto prazo, marketing local e corte de regulamentações de maneira a atrair investimentos e empregos". Tradução nossa. Ver também o excelente artigo de Otilia Arantes (2003).
} 
desregulamentação dos mercados - inclusive do mercado de trabalho. Mas a crescente dificuldade de valorização do capital na esfera produtiva tem sido respondida, sobretudo, com uma tentativa de valorização do capital no âmbito da esfera financeira, o que resulta em recorrentes bolhas especulativas geradoras de crescentes instabilidades.

Um volume enorme de negócios financeiros realiza-se, hoje, com títulos de dívidas dos governos, uma vez que essas dívidas podem ser permanentemente renegociadas em mercados secundários (securitização). A atuação dos governos, em todas as escalas, tem sido reorientada, nos últimos 30 anos, para atingir graus mais elevados de confiabilidade aos olhos dos investidores institucionais, através de políticas de maior prudência fiscal e orçamentária. Uma série de instituições internacionais, entre as quais o Fundo Monetário Internacional, tem sido responsáveis por pressionar os países a adotarem as reformas necessárias a um maior comprometimento dos governos com o pagamento de dívidas e obrigações, muitas vezes exigindo a realização dessas reformas estruturais como condição para a obtenção de auxílio financeiro em momentos de crise - crises que, por sua vez, têm sido geradas em muitos casos pela desregulamentação das finanças ${ }^{135}$. De duas formas esse processo atingiu os governos locais: por um lado, a exigência de moderação orçamentária e fiscal traduz-se, no mais das vezes, em um corte de gastos em serviços importantes para o bem-estar social, e hoje existem instituições de avaliação de riscos que classificam a confiabilidade dos inúmeros governos (locais, regionais, nacionais) em honrar seus compromissos - Jason Hackworth (2007), por exemplo, mostra que as agências de avaliação de riscos desempenham um papel disciplinador ímpar sobre os governos municipais dos Estados Unidos, de maneira que a meta de atingir a nota máxima na avaliação, de forma a obter crédito com maior facilidade, tem restringido as possibilidades de autonomia dos governos locais. Por outro lado, frente a uma competição acirrada entre os governos locais para obter investimentos - seja no setor industrial, ou no de serviços, comércio e imobiliário - os exíguos recursos municipais de um orçamento "enxugado" têm sido direcionados para atender as necessidades de infra-estrutura física e

${ }^{135}$ Cf. Gowan (2003). 
social para a valorização do capital, como afirmamos acima. Ao mesmo tempo, em função da guerra fiscal que se estabelece entre os governos, o orçamento local fica, ademais, prejudicado, pois os governos praticam inúmeras formas de renúncia fiscal e concedem generosos subsídios para atrair as empresas.

Chegamos então ao ponto em que se torna imperativo observar, juntamente com Duménil e Levy (2005), que o neoliberalismo consiste em uma configuração do poder social desenhada para salvaguardar a remuneração dos credores, acionistas e detentores de títulos financeiros em geral. A metrópole atual torna-se refém dessa configuração e suas opções de políticas alternativas restringem-se na exata proporção em que esse poder financeiro se fortalece. Reafirma-se, então, no plano da cidade atual, a segregação sócio-espacial: por um lado, por investimentos estatais sempre mais concentrados em áreas restritas da cidade, aquelas que podem receber os negócios de gestão e administração do capital financeiro, dos serviços e comércio de alto padrão, e do investimento imobiliário residencial de alto padrão, como foi o caso do Jardim Europa, o que muitas vezes recebe o aval e o apoio de instituições supra-nacionais como o BID e o Banco Mundial; por outro, face um orçamento rigidamente comprometido à "boa gestão" - aquela que recebe o louvor das agências de avaliação de riscos - são diminuídos, na maior parte das vezes, os investimentos em infra-estrutura social e física nas áreas mais pobres, bem como os projetos de habitação social que, como vimos ao longo do trabalho, são tão necessários visto que o mercado habitacional não consegue abranger esse segmento não-rentável da demanda. Isso tudo resulta na consolidação do que Amélia Damiani denominou território da ação estatista como aquele em que "a política cola na economia e o processo econômico não é necessariamente civilizador" (DAMIANI, 2008, p. 39) ${ }^{136}$. O recrudescimento dos padrões de desenvolvimento desigual em dois níveis é, portanto e inevitavelmente, um resultado dessas transformações na gestão urbana: no nível intra-urbano o desenvolvimento desigual acentua-se porque os investimentos concentram-se em áreas diminutas da cidade, aquelas que possuem o potencial de atrair os negócios; no nível interurbano porque se trata

${ }^{136}$ Ver também Carlos (2005). 
de um jogo de soma zero, no qual a vitória de algumas cidades em termos de crescimento econômico sinaliza o malogro de muitas outras ${ }^{137}$.

É preciso, enfim, que a análise, que o movimento do pensamento permita construir as mediações para penetrar na aparência de visibilidade do espaço, conforme as constantes alertas de Henri Lefebvre (2000a; 2000b). Esse processo em que o econômico cola no político, em que a valorização do espaço e a violência estatista se atravessam e se alimentam não aparece na superfície, mas requer um cuidadoso exame para que seus liames mais recônditos, seus nós mais apertados possam ser desatados e enfim compreendidos. Também esse processo não se realiza sem contradições, sem choques (télescopages), sem tensões entre os níveis do político e o da reprodução do capital ${ }^{138}$.

A resultante dessa configuração peculiar, do ponto de vista da dimensão espacial da sociedade, é o predomínio, por um lado, do espaço abstrato, que tende à negação dos conteúdos sociais particulares pela imposição de uma reiterada "acumulação primitiva do espaço"139; por outro, a cotidianidade realiza-se com o consumo programado, através do qual se impõe o tempo da circulação do capital ao conjunto da vida cotidiana. É desta maneira que se efetiva o conteúdo antiurbano da metrópole, como negação do encontro e da vida cotidiana como uso ${ }^{140}$.

É importante, aqui, então, reconhecer que seria necessário dar um passo adiante, incorporando, na pesquisa, de forma mais completa e mais

${ }^{137}$ Milton Santos afirma que a metrópole, hoje, "torna-se criadora de pobreza, tanto pelo modelo socioeconômico, de que é o suporte, como por sua estrutura física, que faz dos habitantes da periferia (e dos cortiços) pessoas ainda mais pobres" (SANTOS, M., 2005).

${ }^{138}$ Lefebvre afirma que "dans les pays capitalistes, les contradiction peut s'accentuer entre les buts particuliers des promoteurs, spéculateurs, investisseurs (agents de la production de cet espace) et les buts généraux (stratégiques) de l'État, représentés par la technostructure étatique" (LEFEBVRE, 1978, v. 4, p. 300). Tradução nossa: "nos países capitalistas, as contradições podem se exacerbar entre os objetivos particulares dos promotores, especuladores, investidores (agentes da produção do espaço) e os objetivos gerais (estratégicos) do Estado, representados pela tecnoestrutura estatista".

${ }^{139}$ Cf. Damiani (2004).

${ }^{140}$ Cf. Alfredo (2003), para quem a "cidade" representaria os conteúdos negativos no interior da metrópole entendida como reiteração da valorização do capital por meio da reciclagem dos usos do espaço urbano. Cf. também Sérgio Martins (2008). 
abrangente a dimensão do cotidiano em suas multifacetadas manifestações. Isto porque as abstrações representadas pela circulação do valor no ambiente construído e pela coalizão entre o poder público e o circuito secundário monopolista para a permanente reciclagem do espaço urbano a fim de realizálo como valor de troca, ainda que sempre sejam abstrações, são abstrações bastante concretas, que impõem constrangimentos muito particulares ao espaço como vivido, um ponto sobre o qual Henri Lefebvre sempre insistiu. Uma reflexão que pretende chegar à totalidade das relações sociais e do espaço social entendido como expressão dessas relações, uma meta que, como vimos no início do trabalho, o método dialético propõe-se a atingir, deve sempre chegar ao vivido, ao cotidiano, porque é nele que se realizam as imposições abstratas do valor autonomizado (e da imagem, como o capítulo anterior expôs) e da violência estatista que busca a coerência social. Se esta investigação não foi efetivada de maneira satisfatória neste trabalho, isto se deve muito mais às restrições de tempo que se colocam a um trabalho desta natureza do que a uma falta de vontade de realizar o caminho completo. Concluímos o trabalho, portanto, tendo em vista esta possibilidade de abertura, de continuação. Se é através de uma quantificação crescente do social que o valor autonomizado se realiza, somente um entendimento do cotidiano enquanto, ao mesmo tempo, conjunto de constrangimentos e conjunto de possibilidades, permitir-nos-ia divisar as brechas que apontam para um predomínio do qualitativo sobre aquele do quantitativo. Em outras palavras, do vivido em relação ao fetichismo do dinheiro autonomizado e à ação estatista. 


\section{Referências}

ABramo, Pedro. A cidade caleidoscópica: coordenação espacial e convenção urbana. Rio de Janeiro: Bertrand Brasil, 2007.

Adorno, T. W. \& HorkHeimeR, M. Dialética do esclarecimento. Rio de Janeiro: Jorge Zahar, 1985.

Alfredo, Anselmo. Cidade e metrópole, uma identidade contraditória no processo de urbanização contemporânea. In: CARLOS, Ana Fani Alessandri \& LEMOS, Amália Inês Geraiges (org.). Dilemas urbanos: novas abordagens sobre a cidade. São Paulo: Contexto, 2003.

ARANTES, Otilia. Uma estratégia fatal: a cultura nas novas gestões urbanas. In: ARANTES, Otilia; MARICATO, Erminia; VAINER, Carlos (orgs.). A cidade do pensamento único: desmanchando consensos. Petrópolis/RJ: Ed. Vozes, 2000.

ARAúJo, Rozana Rivas de. A dinâmica de estruturação de estoques residenciais urbanos. Estudo de caso: o entorno do shopping center Iguatemi em Porto Alegre/RS. Porto Alegre: PROPUR/UFRGS, 2005. (Dissertação de Mestrado).

AZEVEdo, Sérgio de; RIBEIRO, Luiz Cezar de Queiroz. A produção de moradia nas grandes cidades: dinâmica e impasses. In: AZEVEDO, Sérgio de \& RIBEIRO, Luiz Cezar de Queiroz (org.). A crise da moradia nas grandes cidades: da questão da habitação à reforma urbana. Rio de Janeiro: Editora UFRJ, 1996.

BALL, Michael. Housing policy and economic power: the political economy of owner occupation. New York \& London: Methuen, 1983.

BASSETT, Keith \& SHORT, John. Housing and residential structure: alternative approaches. London: Routledge, 1980.

BotelHo, Adriano. O urbano em fragmentos: a produção do espaço e da moradia pelas práticas do setor imobiliário. São Paulo: Annablume, 2007.

BRENNER, Neil. The urban question as a scale question: reflections on Henri Lefebvre, Urban theory and the politics of scale. In: International Journal of Urban and Regional Research, 24, 2 (2000): 361-3.

BRENNER, Neil \& THEODORE, Nik. Spaces of neoliberalism: urban restructuring in North America and Western Europe. New York: Blackwell Publishing, 2003.

BRENNER, Robert. O boom e a bolha: os Estados Unidos na economia mundial. Rio de Janeiro: Record, 2003.

CARlos, Ana Fani Alessandri. A (re)produção do espaço urbano. São Paulo: Edusp, 1994.

Espaço-tempo na metrópole. São Paulo: Contexto, 2001.

A reprodução da cidade como "negócio". In: CARLOS, Ana Fani Alessandri e CARRERAS, Carles (orgs). Urbanização e mundialização: estudos sobre a metrópole. São Paulo: Contexto, 2005.

DAmiANI, Amélia Luísa. As contradições do espaço: da lógica (formal) à (lógica) dialética a propósito do espaço. In: CARLOS, Ana Fani; DAMIANI, Amélia Luísa; SEABRA, Odette Carvalho de Lima. O espaço no fim do século: a nova raridade. São Paulo: Contexto, 2001, p. 48-61.

A Propósito do Espaço e do Urbano: algumas hipóteses. Revista Cidades. Vol. 1. $\mathrm{N}^{\mathrm{O}} 1,2004$, p. 79-96. 
A Geografia e a produção do espaço da metrópole: entre o público e o privado. In: CARLOS, Ana Fani Alessandri e CARRERAS, Carles (orgs). Urbanização e mundialização: estudos sobre a metrópole. São Paulo: Contexto, 2005.

A metrópole na dialética entre o território de ação estatista e o espaço de projeto político. In : CAMPOS, Andrelino \& SILVA, Catia Antonia da. Metrópoles em mutação : dinâmicas territoriais, relações de poder e vida coletiva. Rio de Janeiro : Revan, 2008, p. 37-53.

Debord, Guy. La société du spectacle. Gallimard: Paris, 1992.

DUMÉNIL, Gerard e LÉVY, Dominique. O neoliberalismo sob a hegemonia norteamericana. In: Chesnais, François (org.). A finança mundializada: raízes sociais e políticas, configuração, conseqüências. São Paulo: Boitempo, 2005.

FAINSTEIN, Susan S. The city builders: property development in New York and London, 1980-2000. Cambridge: Blackwell, 1995.

FERRAZ FILHO, Galeno Tinoco. Considerações sobre a oferta de imóveis novos na década de 80 (Rio de Janeiro/São Paulo/Porto Alegre). In: AZEVEDo, Sérgio de \& RIBEIRO, Luiz Cezar de Queiroz (org.). A crise da moradia nas grandes cidades: da questão da habitação à reforma urbana. Rio de Janeiro: Editora UFRJ, 1996.

FISHMAN, Robert. Bourgeois utopias: visions of suburbia. In: FAINSTEIN, Susan \& CAMPBELL, Scott (org.). Readings in urban theory. Cambridge: Blackwell, 1996.

FIORI, José Luís. O vôo da coruja: para reler o desenvolvimentismo brasileiro. Rio de Janeiro: Record, 2003.

FIX, Mariana. São Paulo cidade global: fundamentos financeiros de uma miragem. São Paulo: Boitempo, 2007.

GOTTDIENER, Mark. The social production of urban space. Austin: University of Texas Press, 1994.

GoUGH, Jamie. Changing scale as changing class relations: variety and contradiction in the politics of scale. In: Political Geography, Vol. 23, 2004, pp. 185-211.

GoWAN, Peter. A roleta global. Rio de Janeiro: Record, 2003.

HACKWORTH, Jason. The neoliberal city: governance, ideology and development in American urbanism. New York: Cornell University Press, 2007.

HARVEY, David. A justiça social e a cidade. São Paulo: Hucitec, 1980.

1989.

. The urban experience. Baltimore: The Johns Hopkins University Press, . The limits to capital. New York: Verso, 1999.

2001. Spaces of capital: towards a Critical Geography. Routledge: New York, . The new imperialism. Oxford: Oxford University Press, 2003.

JAMESON, Fredric. A virada cultural. Rio de Janeiro: Record, 2006.

LefEBVRE, Henri. Le manifeste differencialiste. Paris: Gallimard, 1970.

1975.

Lógica formal/Lógica dialética. Rio de Janeiro : Civilização Brasileira, De l'État. Paris : Union Génerale d'Éditions, 1978, 4v.

. A vida cotidiana no mundo moderno. São Paulo: Ática, 1991.

A cidade do capital. Rio de Janeiro : DP\&A, 1999. 
. La production de l'espace. Paris: Anthropos, 2000a.

. Espace et politique. Paris: Anthropos, 2000b.

. O direito à cidade. São Paulo: Centauro, 2001.

. La survie du capitalisme: la reproduction des rapports de production.

Paris: Anthropos, 2002.

. The urban revolution. Minneapolis: University of Minnesota Press, 2003.

LOJKINE, Jean. O Estado capitalista e a questão urbana. São Paulo: Martins Fontes, 1997.

LUKACS, Georg. História e consciência de classe. São Paulo: Martins Fontes, 2003.

MARASCHIN, Clarice. Alterações provocadas pelo shopping center em aspectos da estrutura urbana: Iguatemi, Porto Alegre/RS. Porto Alegre: PROPUR/UFRGS, 1993. (Dissertação de Mestrado).

MARCUSE, Herbert. One-dimensional man. New York: Routledge, 2002.

MARTINS, José de Souza. A sociabilidade do homem simples. São Paulo: Contexto, 2008.

MARTINS, Sérgio. A neutralização do direito à cidade na (re)produção da metrópole antiurbana. In: CAMPOS, Andrelino \& SILVA, Catia Antonia da. Metrópoles em mutação : dinâmicas territoriais, relações de poder e vida coletiva. Rio de Janeiro: Revan, 2008, p. 37-53.

MARX, Karl. O capital: crítica da economia política. São Paulo: Civilização Brasileira, 1980. 3 vol.

Capital: a critique of political economy. London: Penguin, 1981, v. 3.

Manuscritos econômico-filosóficos. São Paulo: Boitempo, 2004.

MeRRIFIELD, Andy. Dialectical urbanism: social struggles in the capitalist city. New York: Monthly Review Press, 2002.

Miele, Sávio Augusto. O movimento da economia financeira na dinâmica imobiliária de São Paulo. São Paulo, FFLCH/USP, 2007. (Dissertação de Mestrado)

MONTEIRO, Charles. Porto Alegre no século XX: crescimento urbano e mudanças sociais. In: Porto Alegre em destaque: história e cultura. Porto Alegre: Edipucrs, 2004.

OrTIZ, Renato. Cultura brasileira e identidade nacional. São Paulo: Brasiliense, 1994.

PADILHA, Valquíria. Shopping Center: a catedral das mercadorias. São Paulo: Boitempo, 2006.

QUEIROz RIBEIRO, Luiz César de. Dos cortiços aos condomínios fechados: as formas de produção da moradia na cidade do Rio de Janeiro. Rio de Janeiro: Civilização Brasileira, 1997.

ROCHE, Jean. Porto Alegre, metrópole do Brasil meridional. In: AB'SABER, Aziz; ROCHE, Jean (orgs.).Três estudos Rio-grandenses. Porto Alegre: Gráfica da UFRGS, 1966.

RovatTI, João F. Contribuição ao estudo do planejamento: promoção imobiliária e uso do solo planificado na cidade de Porto Alegre. Rio de Janeiro, IPPUR/UFRJ, 1990 (Dissertação de Mestrado).

A produção mercantil de apartamentos em Porto Alegre (anos 80). In: AZEVEDO, Sérgio de \& RIBEIRO, Luiz César de Queiroz (org.). A crise da moradia 
nas grandes cidades: da questão da habitação à reforma urbana. Rio de Janeiro: Editora UFRJ, 1996.

SANTOS, César Ricardo Simoni. Dos negócios na cidade à cidade como negócio: uma nova sorte de acumulação primitiva do espaço. In: Revista Cidades, no 5, 2006, p. 101-122.

SANTOS, Milton. A urbanização brasileira. São Paulo: Edusp, 2005.

SERPA, Angelo. O espaço público na cidade contemporânea. São Paulo: Contexto, 2007.

SMITH, Neil. The New Urban Frontier: gentrification and the revanchist city. New York: Routledge, 1996.

. New globalism, new urbanism: gentrification as global urban strategy. In: Antipode 34 (3), 427-450, 2002.

A gentrificação generalizada: de uma anomalia local à "regeneração" urbana como estratégia urbana global. In: BIDOU ZACHARIASEN, Catherine. De volta à cidade: dos processos de gentrificação às políticas de "revitalização" dos centros urbanos. São Paulo: Annablume, 2006.

Gentrificação, a fronteira e a reestruturação do espaço urbano. In: Revista Geousp, ํㅡㄴ 21, 2007, p. 15-31.

SouzA, Célia Ferraz de; MüLleR, Dóris Maria. Porto Alegre e sua evolução urbana. Porto Alegre: Editora da UFRGS, 2007.

STROHAECKER, Tania. Atuação do público e do privado na estruturação do mercado de terras de Porto Alegre (1890-1950). Scripta Nova. Revista electrónica de geografia y ciencias sociales. Barcelona: Universidad de Barcelona, 2005, vol. IX, num. 194.

UEDA, Vanda. O mercado imobiliário na cidade de Porto Alegre (RS): os novos empreendimentos e as suas transformações no espaço urbano. In: Rogério Leandro Lima da Silveira, Paulo César Xavier Pereira, Vanda Ueda. (Org.). Dinâmica imobiliária e reestruturação urbana na América Latina. 1 ed. Santa Cruz do Sul: UNISC, 2006, v. 1, p. 92-115.

WEBER, Rachel. Extracting value from the city: neoliberalism and urban redevelopment. In: Antipode: a Radical Journal of Geography, 34,3 (2002): 519-540.

VILLAÇA, Flávio. Espaço intra-urbano no Brasil. São Paulo: Studio Nobel: FAPESP, 2001.

VolochKo, Danilo. A produção do espaço e as estratégias reprodutivas do capital: negócios imobiliários e financeiros em São Paulo. São Paulo: FFLCH/USP, 2007. (Dissertação de mestrado).

ZIZEK, Slavoj. Multiculturalismo, ou a lógica cultural do capitalismo multinacional. In: Duncker, Cristian; Prado, José Luiz Aidar. Zizek crítico: política e psicanálise na era do multiculturalismo. São Paulo: Hacker editores, 2005.

ZUKIN, Sharon. The culture of the cities. Cambridge, USA: Blackwell Publishers, 1995. 
REVISTAS E JORNAIS

Folha de S. Paulo.

Zero Hora.

Valor Econômico.

Boletim Econômico do Sinduscon/RS

Revista da ABECIP

ENDEREÇOS DE INTERNET

Capa Engenharia (www.capa.com.br)

Goldsztein S.A. (www.goldsztein.com.br)

Portal Exame. (www.portalexame.abril.com.br)

Empresas Rodobens (www.rodobens.com)

DOCUMENTOS CONSULTADOS

Câmara Brasileira da Indústria da Construção. Construção: cenários e perspectivas. Brasília, Dezembro de 2007.

FGV Projetos. O crédito imobiliário no Brasil: caracterização e desafios. São Paulo: Fundação Getúlio Vargas, 2007.

Prefeitura Municipal de Porto Alegre. Plano Diretor de Desenvolvimento Urbano Ambiental. Porto Alegre, 1997.

PROFIL Engenharia e Ambiente. Relatório de Impacto Ambiental do Loteamento Germânia. Porto Alegre, 2001.

SINDUSCON-RS. Censo do Mercado Imobiliário de Porto Alegre (2006). Porto Alegre, 2006.

2007. . Censo do Mercado Imobiliário de Porto Alegre (2007). Porto Alegre, 